\title{
6. SITE 392: SOUTH RIM OF BLAKE NOSE
}

\author{
Shipboard Scientific Party ${ }^{1}$
}

\section{SITE DATA}

Dates Occupied: 23-28 September 1975

Position: $29^{\circ} 54.63^{\prime} \mathrm{N} ; 76^{\circ} 10.68^{\prime} \mathrm{W}$

Water Depth: 2601.0 meters (corrected PDR), 2606.5 meters (drill pipe)

Penetration: 349 meters

Number of Holes: 2

Number of Cores: 35

Total Length of Cored Section: 295.0 meters

Total Core Recovered: 37.9 meters

Percentage Core Recovered: 12.8 per cent

Oldest Sediment Cored: Neocomian or older recrystallized skeletal limestone at 349 meters sub-bottom.

Basement: Not reached

Principal results: We drilled two holes at Site 392; Hole 392 was abandoned when the bit encountered hard limestone at 48 meters - too shallow to adequately seat the bottom-hole assembly. We successfully spudded in Hole 392A, 1500 feet to the northwest. Coring began at 50.5 meters sub-bottom in pale brown ooze and continued in mostly soft sediment to 99 meters where hard "reef"' limestone was encountered. The hard "reef" limestone was cored continuously until the bit was destroyed at 349 meters sub-bottom.

The sedimentary sequence at Site 392 is essentially the same as that at Site 390. The Campanian/Albian unconformity present at Site 390 is also present at Site 392 indicating its persistence along the edge of the Blake Nose. Upper Campanian ooze directly overlies Aptian-Albian ooze and the lower half of the Upper Cretaceous is missing. A thin interval of Barremian ooze overlies hard shallow-water limestone. The top of the limestone is brecciated, stained and cemented with limonite, and contains limonite ooids. Below this the limestone is of the three general types: (1) fenestral limestone, (2) oolite, and (3) a skeletal moldic limestone. Fossils are all shallow-water types. All the limestone has been recrystallized and some of the diagenesis must have occurred above the water table.

Shallow-water limestone accreted during the Ealry Cretaceous, but accumulation ceased by late Neocomian or certainly by early Barremian time, after which accretion did not keep pace with subsidence and only pelagic oozes accumulated.

'William E. Benson and Robert E. Sheridan, Chief Scientists; Paul Enos, Tom Freeman, Felix M. Gradstein, Ivar O. Murdmaa, Léo Pastouret, Ronald R. Schmidt, Daniel H. Stuermer, Fred M. Weaver, Paula Worstell.

\section{BACKGROUND AND OBJECTIVES}

\section{Background}

Site 392, situated on the southeastern lip of the Blake Nose (Figures 1 and 2) was drilled to supplement our information about Cretaceous limestones drilled at Sites 389 and 390 .

Cretaceous reefs and related structures form a chain that circles the Gulf of Mexico, extends through Cuba and the Bahamas, and rims the escarpment of the Blake Plateau (Figure 3, Site 390, after Paulus, 1972, and Meyerhoff and Hatten, 1974). Seismic reflection data have suggested that this reef and bank-rim complex extended from Cape Hatteras to off the coast of New Jersey and along the edge of the Georges Bank (Sheridan, 1974; Schlee et al., 1976).

In Mexico the Cretaceous reef complex rims petroleum-bearing limestone platforms (Golden Lane Atoll, Enos, 1974) and in Texas it is recognized as a zone of stratigraphic traps (Edwards Limestone, or Stuart City reef). Despite its economic importance in the Gulf area, the age and structure of the reef complex along the Atlantic continental margin are poorly known and the time the reef complex ceased to build and subsequently sank is poorly documented. Piston core and dredging data along the Blake Escarpment indicate that a complex reef-lagoon facies existed from at least Neocomian to Cenomanian or Campanian time (Heezen and Sheridan, 1966; Sheridan et al., 1971) and drilling at Site 390 showed that the carbonate shelf was built during Barremian time at that site.

\section{Objectives}

The primary objective of this site was to drill into the massive part of the Blake Nose reef bank-rim complex and to study the makeup of this facies (Figure 4). We also planned to tie Site 392 into the geologic profile interpreted from Site 390 drilling to test the interpretation and give a more definitive picture of Blake Nose reef structure.

\section{OPERATIONS}

We approached Site 392 from the southeast and conducted a seismic survey along a course of $300^{\circ}-$ following a track similar to that approaching Sites 389 and 390 (Figures 5 and 6). We selected the location for Site 392 on the prominent reef-like structure near the south edge of the Blake Nose. A 16- $\mathrm{kHz}$ beacon was dropped at 0605 hours $^{2} 23$ September 1975 where 100 meters of overlying sediment $(0.1 \mathrm{sec})$ appeared sufficient cover to seat the bit. Glomar Challenger continued on course to record the

${ }^{2}$ Time in text is local time. 


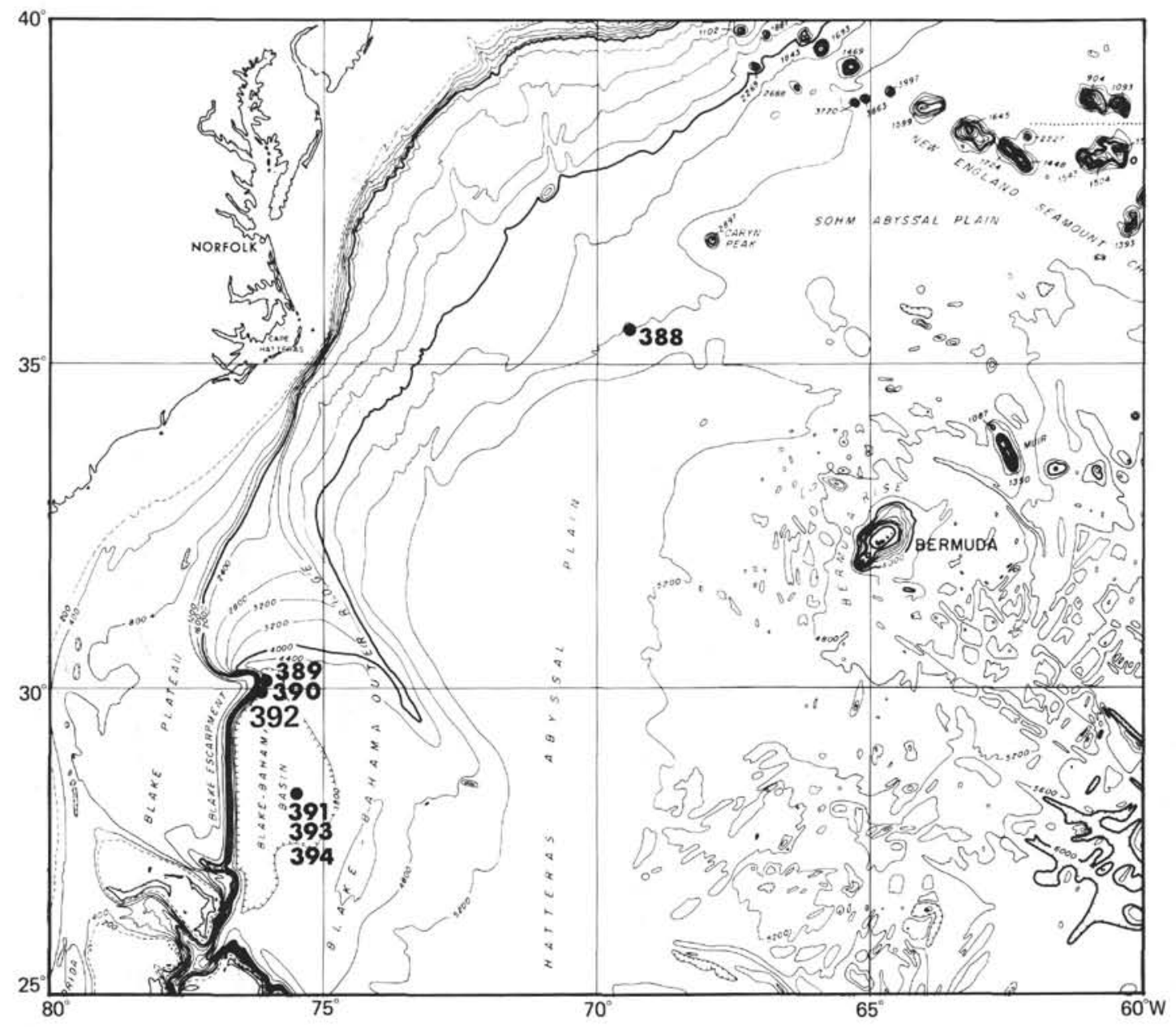

Figure 1. Map showing location of Site 392 relative to the Atlantic margin.

sedimentary reflectors northwest of the structure so that we could correlate them with those reaching Site 390 .

As shown on Site 389 profile (Figure 7), the Site 392 seismic profile (Figure 8 ) shows that the reef was draped with beds dipping northwest into the nose but clearly truncated by erosion along the Blake Escarpment. This truncation on the southeast precluded entrapment of any petroleum so that we could drill the site without danger of pollution.

We returned the Challenger to the beacon, lowered hydrophones, and began automatic positioning by 0745 hours. Several hours were required to center over the beacon because of $35-\mathrm{kt}$ winds and 10-15 foot swells coming from the southwest. The water depth is 2605 meters corrected (1424 fm corrected, $1386 \mathrm{fm}$ uncorrected). The pipe was run in at 1130 hours and bottom was felt at 2609.5 meters - a little shallower than anticipated suggesting some local relief on the bottom. Following a delay to repair the Bowen power sub and recover the ship's position, we spudded in at 2030 hours and washed down to 47.5 meters.

Soft but firm sediments were encountered to only 42 meters sub-bottom where the bit hit hard limestone and rubble rock. Our estimate of soft sediment overburden was incorrect or the beacon had reached bottom a little south of the drop point. Nevertheless the sediment cover was insufficient to seat the bit. Consequently, we pulled pipe above mud line at 0100 on 24 September 1975, and offset 1500 feet northwest (Figure 6), where our profile showed much thicker sediments.

Hole 392A was spudded in at 0440 hours at a different water depth of 2601 meters corrected (1422 fm corrected, $1384 \mathrm{fm}$ uncorrected). Felt depth was 2606.5 meters. Here the hard limestone of the reef complex was reached at 89 to 98 meters sub-bottom - deep enough so that the bit could be sufficiently weighted and torqued to continuously drill the hard limestone.

We continuously cored the hard limestone to a sub-bottom depth of 349 meters. Penetration was extremely slow (about $120+$ minutes per core) and recovery was very poor, comprising, at times, no more than a few fragments of hard limestone in the core catcher.

The poor recovery apparently was not caused by technical malfunction. The bit neither jammed nor clogged and the seating of the inner core barrel was normal. The limestone itself was simply very difficult to drill. The limestone is recrystallized, and very brittle, and has healed sheeting joints parallel to bedding. Presumably, the weight of the bit cracked this brittle limestone along the horizontal planes and $3-8 \mathrm{~cm}$ thick fragments were rolled around between the cones of the bit, instead of moving easily into the core barrel. The result was recovery of a number of lens-shaped limestone discs in the bottom of the core barrel. Cores 27 


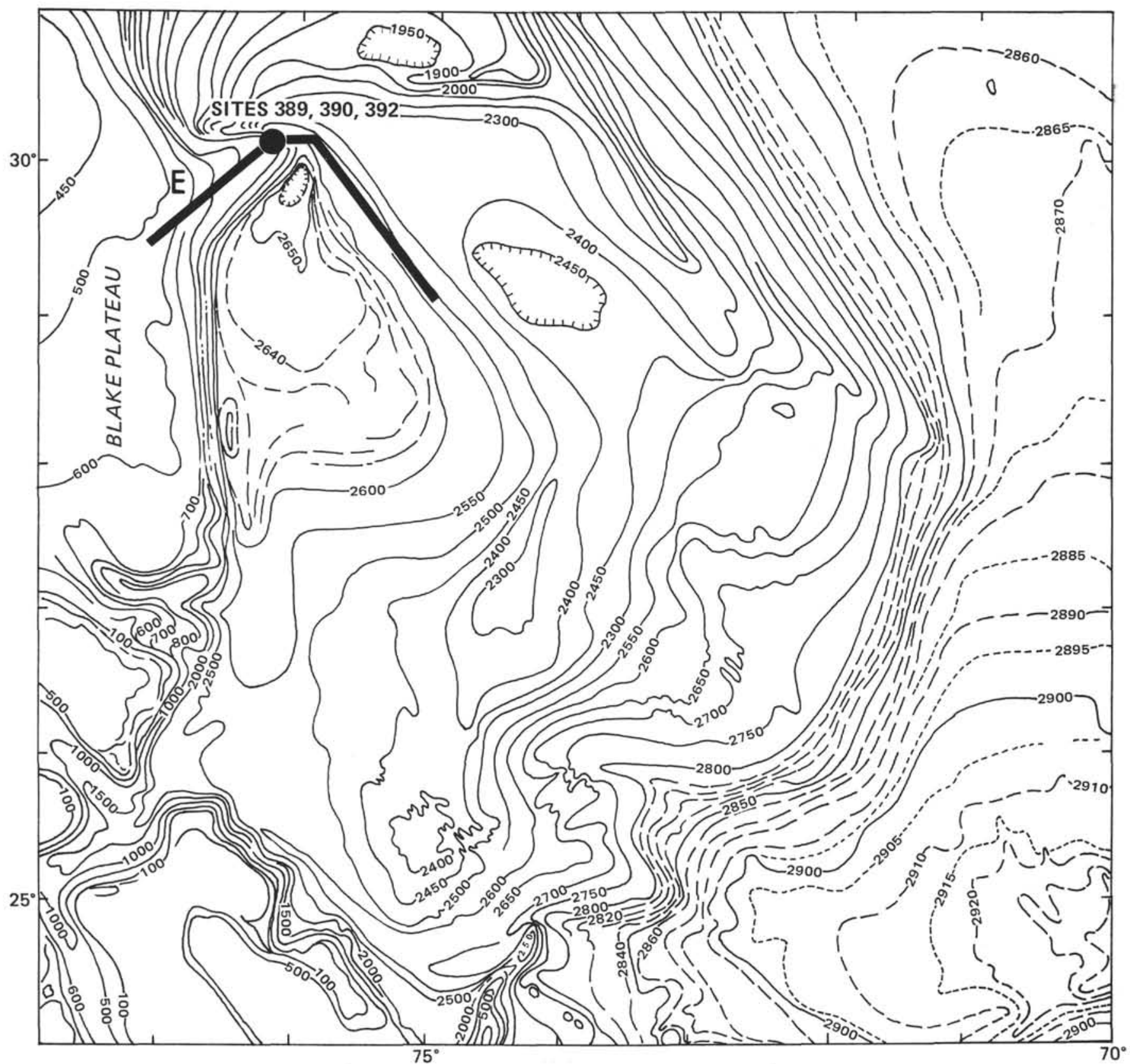

Figure 2. Detailed bathymetry in the vicinity of Sites 389, 390 and 392. Depths in fathoms are on the basis of computations of E. Schneider (pers. comm.). Profile along track E is shown in Figure 3.

and 28 at 288 and 297.5 meters sub-bottom, respectively, were cut comparatively rapidly, $35-60 \mathrm{~min} /$ core, and we recovered some cavernous limestone fragments. Apparently a limestone cavern of at least 10 meters depth was penetrated.

We cored continuously until 1630 hours 27 September, when, because of extremely slow drilling rates, inability to recover material, and time constraints, we terminated Hole $392 \mathrm{~A}$ at a depth of 349 meters.

The tools were on deck by 0230 hours 28 September and Challenger left Site 392 bound for port. The bit had been drilled to destruction. Although less than 250 meters of hard limestone was penetrated two cones were gone and the other two had no bearings and were held in place only by bent and twisted cone guides. Nearly 90 per cent of the tungsten buttons had been plucked from the remaining cones.

Drilling in Hole 392A penetrated 349 meters of soft ooze and hard limestone. The hole terminated in Barremian or older limestone. We recovered two cores from Hole 392 and attempted 33 cores in Hole 392A. Drilling results are given in Table 1.

\section{LITHOLOGY}

Our objectives in drilling Site 392 were to examine the nature of the prominent shelf-edge reflector ("reef") shown by seismic profiling of the Blake Nose. Hole 392, drilled on the approximate topographic crest, penetrated manganiferous sediments and carbonate ooze before 


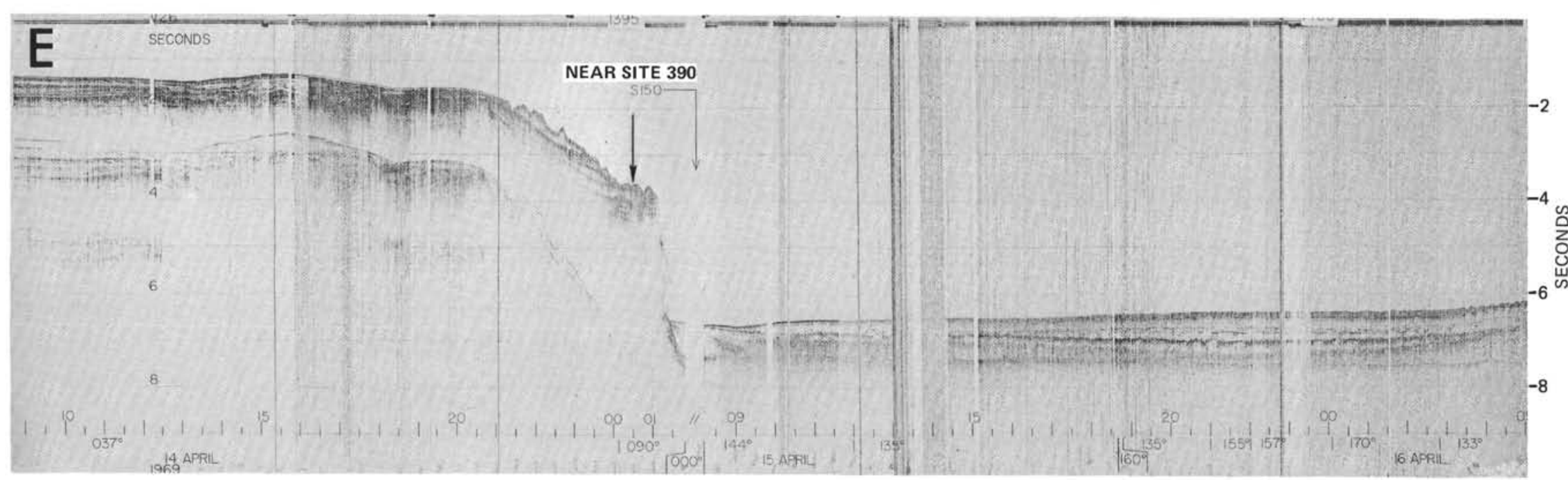

Figure 3. Vema 26 single-channel reflection across the Blake Nose along track E shown in Figure 5. (Data supplied by Lamont-Doherty Geological Observatory.) 

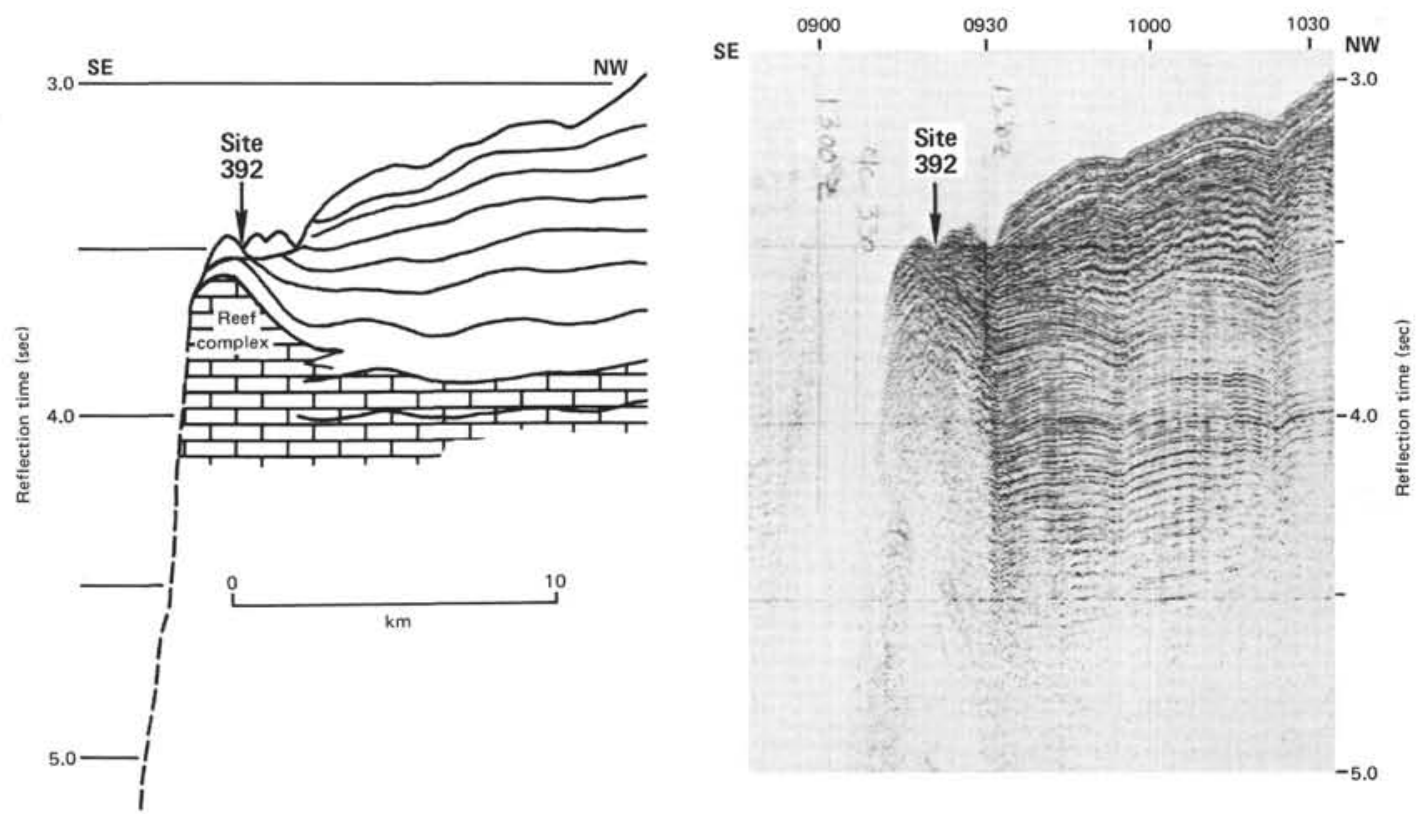

Figure 4. Geologic cross-section across Blake Nose "reef" interpreted on basis of Challenger profile shown on right. Local times are used.

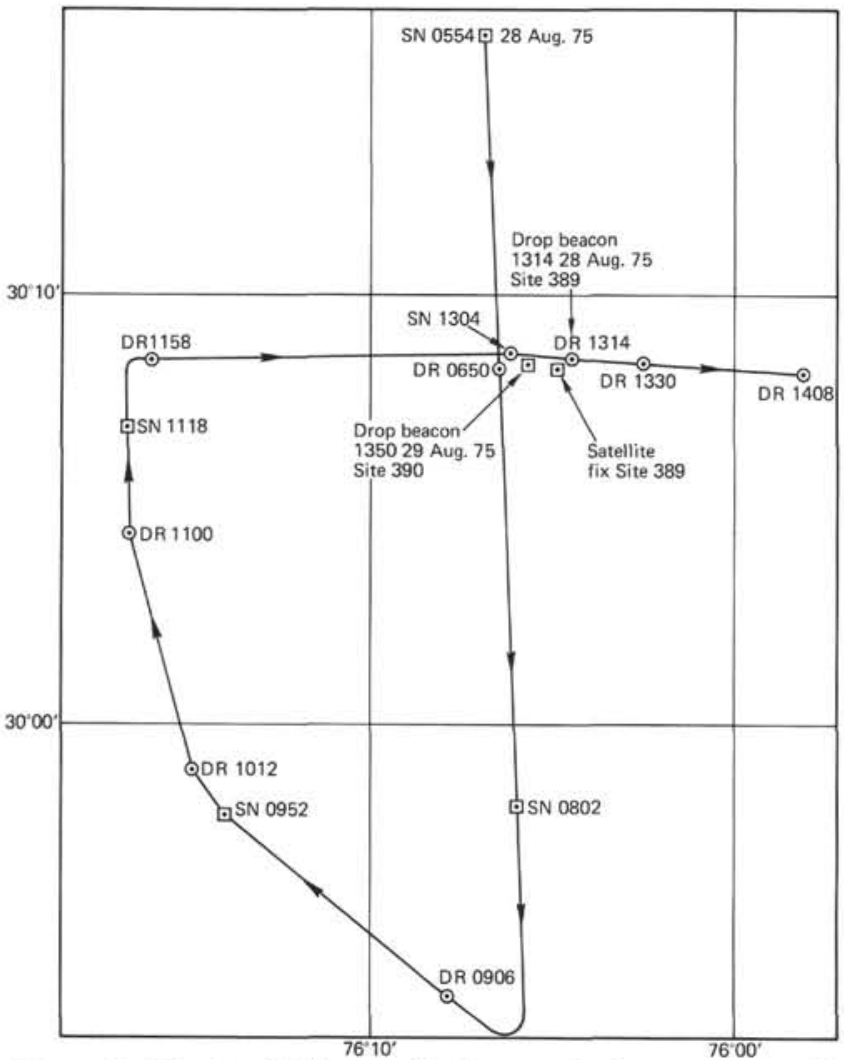

Figure 5. Track of Glomar Challenger during survey made prior to drilling Site 389. Local times are used.

entering lithified limestone at 48 meters sub-bottom. Two cores of limestone were recovered from this hole before we moved 460 meters westward, down the dip of the reflector, to spud into a thicker sediment cover. We continuously cored Hole 392A which penetrated 90 meters of ooze and 259 meters of hard limestone to the termination of the hole

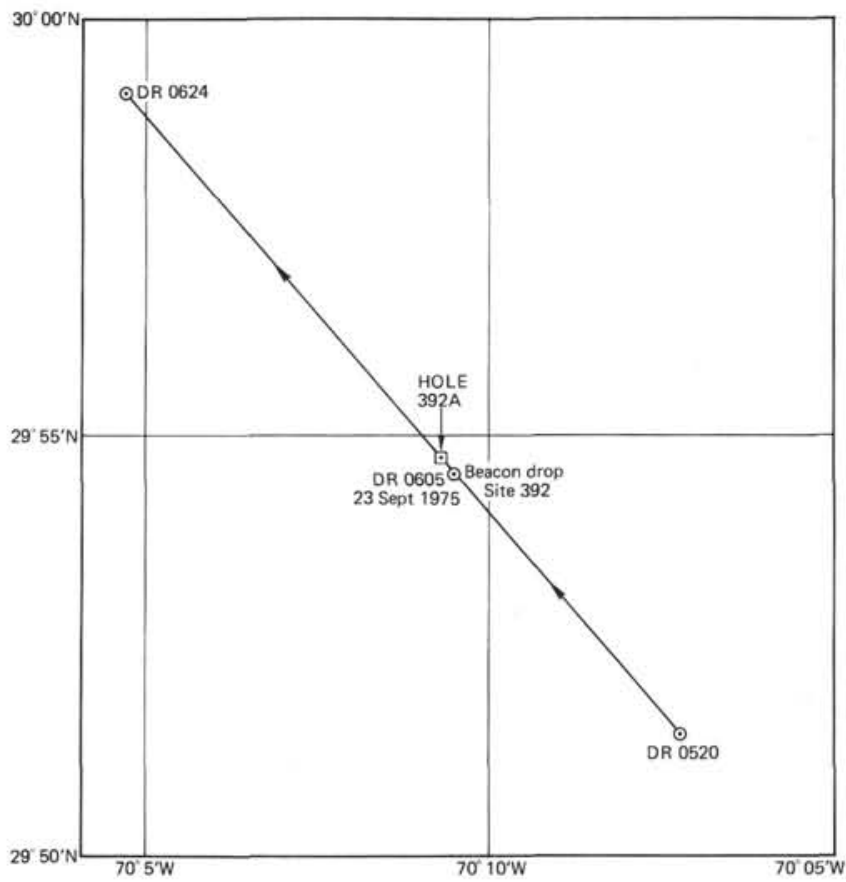

Figure 6. Track of Glomar Challenger on approach to Site 392. Local times are used.

at 349 meters sub-bottom. Recovery was poor (9\%) and cores comprised mostly rounded pieces of limestone which although probably in proper stratigraphic sequence are not contiguous.

\section{Lithologic Units}

We recognized four lithologic units (Table 2, Figure 9). The youngest is ooze and clay representing a condensed Campanian to Barremian section. The underlying three units are limestone - possibly Neocomian in age, but not yet satisfactorily dated. The principal components in the 


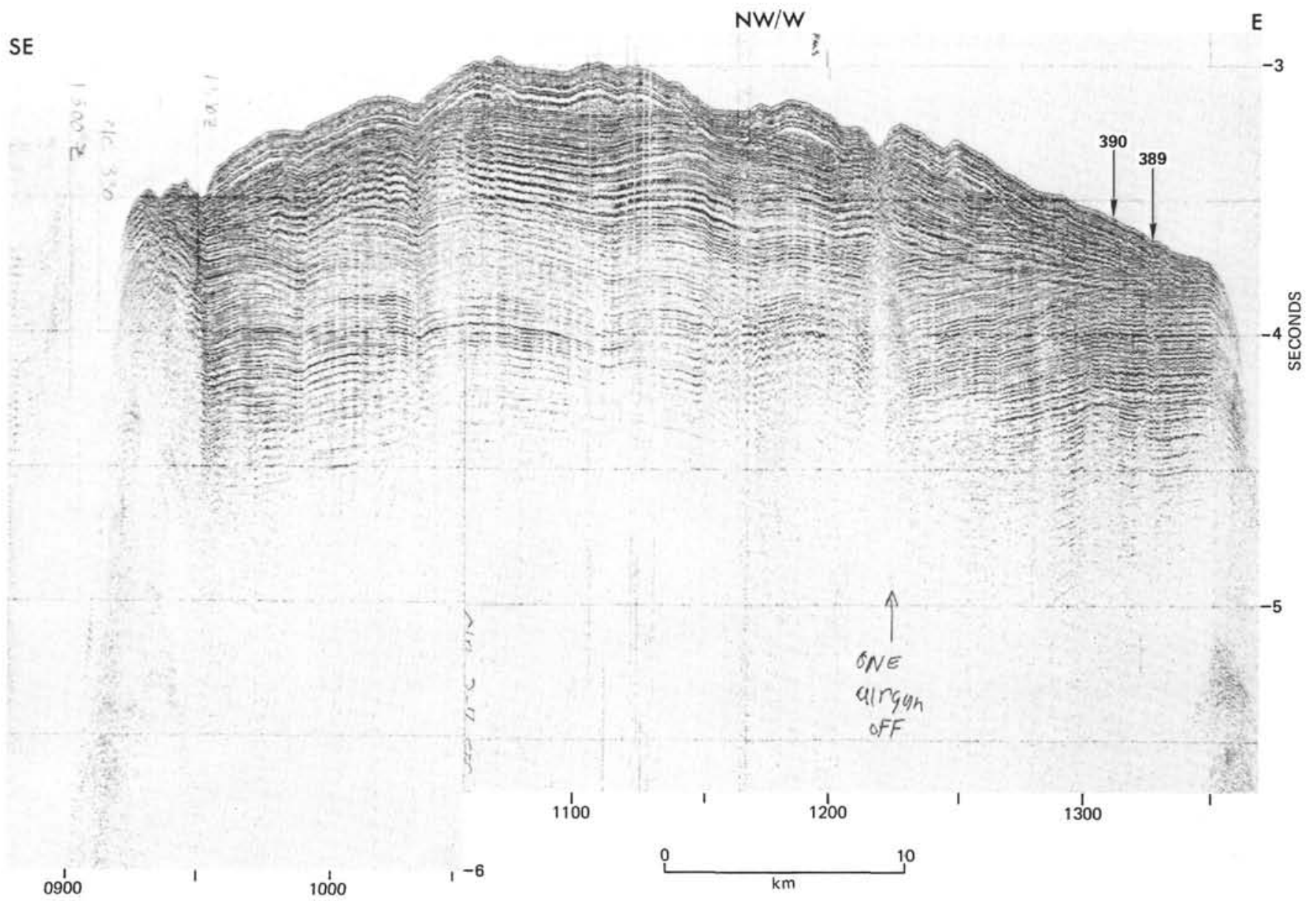

Figure 7. Seismic reflection profile made by Glomar Challenger prior to drilling Site 389 showing location of Site 392. Local times are used.

major and minor lithologies of Hole $391 \mathrm{~A}$ are shown in Figure 10.

\section{Unit 1 - Nannofossil Ooze and Clay (0-99.3 m)}

Unit 1 is dominantly nannofossil ooze with two recognizable nannofossil clay intervals and possibly others which were mixed by drilling. The unit extends to 99.3 meters sub-bottom in Hole 392A, but the interval above 50 meters was not cored.

The nannofossil ooze is soft and white (10YR 8/2) to pale olive (5Y 6/3). The basal 1 meter of Core 392A-3 (about 88 $\mathrm{m})$ is slightly firmer and more colorful, brownish yellow $(10 \mathrm{YR} 6 / 6)$, with a thin $(<5 \mathrm{~cm})$ reddish yellow $(5 \mathrm{YR} 6 / 6)$ and yellow (10YR 7/6) zone. Planktonic foraminifers form up to 20 per cent of the sediment in the upper part of the unit (Core 392A-1). A small terrigenous component, quartz, feldspar, clay, and mica, is present; siliceous skeletons are absent (Table 3). Total calcium carbonate content is 89 per cent in the upper part of the unit (Core 392A-1) and 60 per cent in the lower part (Appendix I, this volume).

Cores 392A-2-1 and -3-1 contain dark gray (10YR 4/1) and greenish gray (5G 4/1) nannofossil clay with about 9 per cent quartz silt. The proportions of constituent particles are the same as in the light-colored oozes except that calcium carbonate, dominantly nannofossils, is reduced to about 40 per cent.

Two pieces (totaling $8 \mathrm{~cm}$ ) of moderately well lithified foraminifer nannofossil ooze occur at 81 meters sub-bottom
(Section 392A-3-2). A second limestone, light brown to pink (10YR 5/3, 10YR 6/4, 5YR 7/4), forms two layers totaling $35 \mathrm{~cm}$ near the base of unit 1 (Core 392A-4). The limestone is composed primarily of large undistorted ammonites closely packed in a matrix of lime mud and planktonic foraminifers.

The contact between unit 1 and the underlying fenestral limestone is at 99.3 meters sub-bottom (in Section $392 \mathrm{~A}-5-1)$. The base of unit 1 is marked by a thin red-stained interval of limestone clasts, skeletal rubble, laminated crusts, and reddish brown ooids. This zone occurs in both Holes 392 and 392A, but at depths differing by 40 meters (subsea and sub-bottom, Cores 392-1, 392A-4, CC and 392A-5). Multiple crusts of lustrous, dark reddish-brown, laminated calcareous material laced through a matrix of dense light gray carbonate, dark brown ooids, and skeletal debris. The skeletal debris includes belemnites, green algae, and a variety of corals. The reddish brown ooids are concentrically laminated oblate spheroids 0.2 to 3 $\mathrm{mm}$ in maximum diameter with spherical to irregular nuclei consisting of earthy, rusty particles (limonite?) or, rarely, of several smaller ooids. The ooids are presumed to be rich in iron. Individual ooids are generally not in contact with each other, although a few areas show contact with possible fitting of slightly polygonal ooids. Major axial planes of adjacent ooids are roughly parallel, but not everywhere horizontal. The ooids form wavy bands that pass not only through the matrix and laminated crusts, but also through 


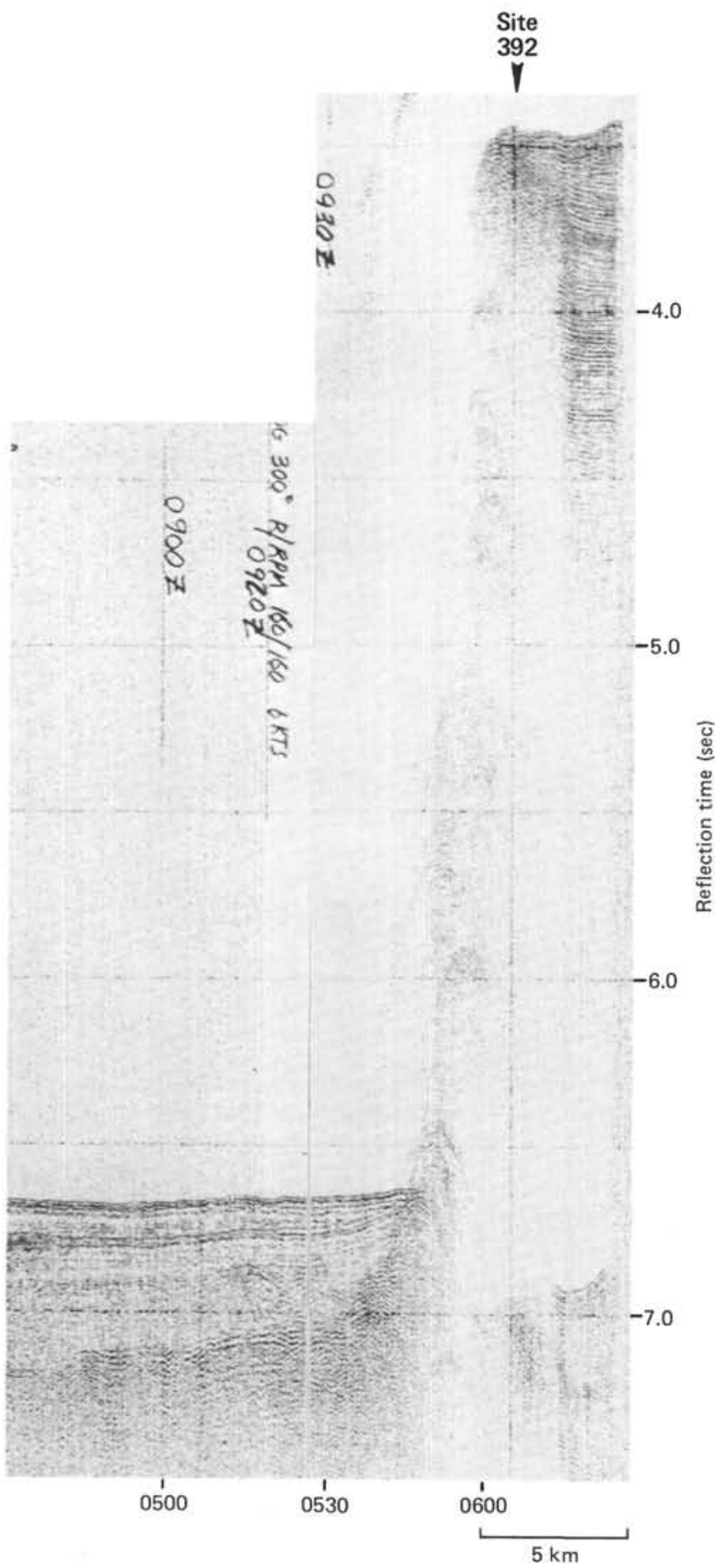

Figure 8. Glomar Challenger single-channel reflection profile across Site 392. Local times are used.

limestone clasts. The clasts consist of skeletal limestone, containing a probable rudist fragment and muddy limestone stained uniformly dark red. Pebbles totaling about $5 \mathrm{~cm}$ were recovered in Core $390-1$ and a total of $13 \mathrm{~cm}$ was recovered from contiguous Cores $392 \mathrm{~A}-4$ and -5 which were continuous, but had only 6 and 18 per cent recovery, respectively.

The remaining three units (2-4) are well-lithified limestones apparently closely related in time, space, and genesis. The lithologic types are interbedded and somewhat intergradational in constituent components, although the "end members" are readily distinguished by sedimentary structures and diagenetic features.

\section{Unit 2 - Fenestral Limestone (99.3-212.8 m)}

Beneath the surficial crust of unit 1 , unit 2 is characterized primarily by its distinctive sedimentary structures, especially disrupted lamination and "fenestral" pores. The unit extends from 99.3 meters to the top of the oolitic limestone of unit 3 (213 m sub-bottom). The limestone is uniformly light in color, mainly very pale brown (10YR $8 / 3$ to $7 / 4$ ). The constituent particles are pelletoids, intraclasts (both predominantly soft at the time of deposition), lime mud, and a few fossils. The fossils include miliolids, other small benthic foraminifers, high-spired gastropods, and very thin-shelled pelecypods, The biota is more varied lower in the section with the presence of green algae (about $160 \mathrm{~m}$ sub-bottom) and coral fragments (195 $\mathrm{m})$.

Much of the rock is poorly laminated muddy layers interspersed with thin $(\mathrm{mm})$ laminae and lenses of commonly micrograded grainy carbonate and with layers of coarse intraclasts. The laminae are warped and disrupted to produce fenestral pores or a "birds-eye" texture (voids elongate parallel to stratification). This type of pore may be formed by desiccation, accumulation of gases beneath cohesive mud layers, and/or algal growth. Mud cracks with polygonal patterns presumed to be formed by desiccation are fairly common on bedding structures. Desiccation probably also accounts for a local "crumb" texture of muddy carbonate and may have produced many of the intraclasts virtually in situ. Other pores consist of vertical or arcuate strings of bubble-like cavities joined by cracks or narrow tubes. The "bubbles" are less than a millimeter in diameter and the strings seen in the cores are several centimeters long. Strings are probably much longer and extend beyond the dimensions of the core. The bubble strings may be burrows with a series of connected galleries or they could record the difficult passage of gas through cohesive sediment. Some of these syndepositional pores were evidently enlarged by solution. Fenestral and visible intergranular pore space commonly exceeded 40 per cent of the bulk volume, but virtually all pore space has been filled during a complex diagenetic history. The remaining porosity of the rock is less than 5 per cent, largely in spar-lined vugs.

Although unit 2 is nearly homogeneous, it contains a few interbeds of finely crystalline limestone characteristic of unit 4 . The disappearance of fenestral fabric coincides with the top of an interval in which coated grains are prominent. This transition, at 212.8 meters marks the contact between units 2 and 3 (Figure 9).

\section{Unit 3 - Oolite (212.8-241.6 m)}

Pale brown oolite (10YR 7/3) with numerous intraclasts, skeletal fragments, varied fossils, and little mud comprises unit 3 . The unit is 29 meters thick and extends to the abrupt disappearance of oolite as a dominant lithology at 241.6 meters. Near the top of the unit the ooids range from thin surficial rims to thick asymmetric coatings, possibly algal. 
TABLE 1

Coring Summary, Site 392

\begin{tabular}{|c|c|c|c|c|c|c|c|}
\hline \multirow[b]{2}{*}{ Core } & \multicolumn{2}{|c|}{ Cored Interval } & \multirow[b]{2}{*}{$\begin{array}{c}\text { Cored } \\
(\mathrm{m})\end{array}$} & \multicolumn{2}{|c|}{ Recovered } & \multirow[b]{2}{*}{ Lithology } & \multirow[b]{2}{*}{$\begin{array}{c}\text { Time-Rock } \\
\text { Unit }\end{array}$} \\
\hline & $\begin{array}{l}\text { Total Depth } \\
(\mathrm{m})\end{array}$ & $\begin{array}{l}\text { Sub-Bottom Depth } \\
(\mathrm{m})\end{array}$ & & (m) & (\%) & & \\
\hline \multicolumn{8}{|l|}{ Hole 392} \\
\hline 1 & $2658.0-2666.5$ & $47.5-57.0$ & 9.5 & 0.2 & 2 & $\begin{array}{l}\text { Mn module and limestone } \\
\text { fragments }\end{array}$ & (Indeterminate) \\
\hline 2 & $2666.5-2669.5$ & $57.0-60.0$ & 3.0 & 3.0 & 100 & Limestone & Quaternary \\
\hline Total & 2669.5 & 60.0 & 12.5 & 3.2 & 26 & & \\
\hline \multicolumn{8}{|c|}{ Hole 392A } \\
\hline 1 & $2657.0-2666.5$ & $50.5-60.0$ & 9.5 & 2.7 & 28 & Nannofossil and foraminifer & Upper Campanian \\
\hline 2 & $2672.5-2676.0$ & $66.0-69.5$ & 3.5 & 3.5 & 100 & Marly nannofossil ooze & Middle-Upper Albian \\
\hline 3 & $2685.5-2695.0$ & $79.0-88.5$ & 9.5 & 3.5 & 37 & $\begin{array}{l}\text { Nannofossil ooze with lime- } \\
\text { stone fragments }\end{array}$ & Lower-Middle Albian; Upper Aptian \\
\hline 4 & $2695.0-2704.5$ & $88.5-98.0$ & 9.5 & 0.6 & 6 & $\begin{array}{l}\text { Nannofossil ooze and } \\
\text { limestone }\end{array}$ & Barremian \\
\hline 5 & $2704.5-2714.0$ & $98.0-107.5$ & 9.5 & 1.7 & 18 & Limestone & (Indeterminate) \\
\hline 6 & $2714.0-2723.5$ & $107.5-117.0$ & 9.5 & 0.9 & 9 & Limestone & (Indeterminate) \\
\hline 7 & $2723.5-2733.0$ & $117.0-126.5$ & 9.5 & 0.2 & 2 & Limestone & (Indeterminate) \\
\hline 8 & $2733.0-2742.5$ & $126.5-136.0$ & 9.5 & 0.2 & 2 & Limestone & (Indeterminate) \\
\hline 9 & $2742.5-2745.5$ & $136.0-139.0$ & 3.0 & 1.5 & 50 & Limestone & (Indeterminate) \\
\hline 10 & $2745.5-2752.0$ & $139.0-145.5$ & 6.5 & 1.6 & 25 & Limestone & (Indeterminate) \\
\hline 11 & $2752.0-2761.5$ & $145.5-155.0$ & 9.5 & 0.95 & 10 & Limestone & (Indeterminate) \\
\hline 12 & $2761.5-2771.0$ & $155.0-164.5$ & 9.5 & 0.1 & 1 & Limestone & (Indeterminate) \\
\hline 13 & $2771.0-2780.5$ & $164.5-174.0$ & 9.5 & 0.05 & 0.5 & Limestone & (Indeterminate) \\
\hline 14 & $2780.5-2782.5$ & $174.0-176.0$ & 2.0 & 0.1 & 5 & Limestone & (Indeterminate) \\
\hline 15 & $2782.5-2790.0$ & $176.0-183.5$ & 7.5 & 0.3 & 4 & Limestone & (Indeterminate) \\
\hline 16 & $2790.0-2799.5$ & $183.5-193.0$ & 9.5 & 0.7 & 7 & Limestone & (Indeterminate) \\
\hline 17 & $2799.5-2809.0$ & $193.0-202.5$ & 9.5 & 1.0 & 11 & Limestone & (Indeterminate) \\
\hline 18 & $2809.0-2818.5$ & $202.5-212.0$ & 9.5 & 0.1 & 4 & Limestone & (Indeterminate) \\
\hline 19 & $2818.5-2828.0$ & $212.0-221.5$ & 9.5 & 0.8 & 7 & Limestone & (Indeterminate) \\
\hline 20 & $2828.0-2837.5$ & $221.5-231.0$ & 9.5 & 0.9 & 11 & Limestone & (Indeterminate) \\
\hline 21 & $2837.5-2847.0$ & $231.0-240.5$ & 9.5 & 0.7 & 7 & Limestone & (Indeterminate) \\
\hline 22 & $2847.0-2856.5$ & $240.5-250.0$ & 9.5 & 0.7 & 7 & Limestone & (Indeterminate) \\
\hline 23 & $2856.5-2866.0$ & $250.0-259.5$ & 9.5 & 0.7 & 7 & Limestone & (Indeterminate) \\
\hline 24 & $2866.0-2875.5$ & $259.5-269.0$ & 9.5 & 0.2 & 2 & Limestone & (Indeterminate) \\
\hline 25 & $2875.5-2885.0$ & $269.0-278.5$ & 9.5 & 0.2 & 2 & Limestone & (Indeterminate) \\
\hline 26 & $2885.0-2894.5$ & $278.5-288.0$ & 9.5 & 0.6 & 6 & Limestone & (Indeterminate) \\
\hline 27 & $2894.5-2904.0$ & $288.0-297.5$ & 9.5 & 0.1 & 1 & Limestone & (Indeterminate) \\
\hline 28 & $2904.0-2913.5$ & $297.5-307.0$ & 9.5 & 0.4 & 4 & Limestone & (Indeterminate) \\
\hline 29 & $2913.5-2923.0$ & $307.0-316.5$ & 9.5 & 0.1 & 1 & Limestone & (Indeterminate) \\
\hline 30 & $2923.0-2932.5$ & $316.5-326.0$ & 9.5 & 0.1 & 1 & Limestone & (Indeterminate) \\
\hline 31 & $2932.5-2942.0$ & $326.0-335.5$ & 9.5 & 0.2 & 2 & Limestone & (Indeterminate) \\
\hline 32 & $2942.0-2951.5$ & $335.5-345.0$ & 9.5 & 0.0 & 0 & - & - \\
\hline 33 & $2951.5-2955.5$ & $345.0-349.0$ & 4.0 & 0.0 & 0 & - & - \\
\hline Total & 2955.5 & 349.0 & 283.0 & 25.3 & 9 & & \\
\hline
\end{tabular}

TABLE 2

Summary of Lithologic Units, Site 392

\begin{tabular}{|c|c|c|c|c|c|c|}
\hline Unit & Lithology & $\begin{array}{l}\text { Time-Rock } \\
\text { Unit }\end{array}$ & $\begin{array}{l}\text { Apparent Thickness } \\
\qquad(\mathrm{m})\end{array}$ & $\begin{array}{l}\text { Sub-Bottom Depth } \\
\text { at Top }(\mathrm{m})\end{array}$ & $\begin{array}{l}\text { Recovered } \\
(\%)\end{array}$ & Cores \\
\hline 1 & $\begin{array}{l}\text { Nannofossil and foraninifer ooze, light } \\
\text { colored and dark gray marly nannofossil } \\
\text { ooze }\end{array}$ & $\begin{array}{l}\text { Campanian, Albian, Upper } \\
\text { Aptian, Barremian }\end{array}$ & $>48.8$ & $<50.5$ & $\sim 20$ & $392 \mathrm{~A}-1$ to $5-1,130 \mathrm{~cm}$ \\
\hline 2 & $\begin{array}{l}\text { Fenestral limestone, pale brown, intra- } \\
\text { clasts, foraminifers, mollusks, laminae, } \\
\text { mud cracks, burrows, fenestral pores }\end{array}$ & Indeterminate & 113.5 & 99.3 & 8.93 & $392 \mathrm{~A}-5-1,130 \mathrm{~cm}$ through $19-1$ \\
\hline 3 & Oolite, intraclasts, fossils, laminated & Indeterminate & 28.8 & 212.8 & 8.73 & $392 \mathrm{~A}-19-2$ through $-22-1,120 \mathrm{~cm}$ \\
\hline 4 & $\begin{array}{l}\text { Skelmoldic limestone, light gray, fossils, } \\
\text { pelletoids, finely crystalline, moldic } \\
\text { porosity }\end{array}$ & Indeterminate & 107.4 & 241.6 & 2.73 & $\begin{array}{l}392 \mathrm{~A}-22-1,120 \mathrm{~cm} \text { through }-31 \\
\text { (No recovery } 32 \text { qnd } 33 \text { ) }\end{array}$ \\
\hline \multicolumn{3}{|c|}{$\begin{array}{l}\text { Total limestone recovered } \\
\text { Total penetration }\end{array}$} & $\begin{array}{l}25.3 \mathrm{~m} \\
349 \mathrm{~m}\end{array}$ & & & \\
\hline
\end{tabular}




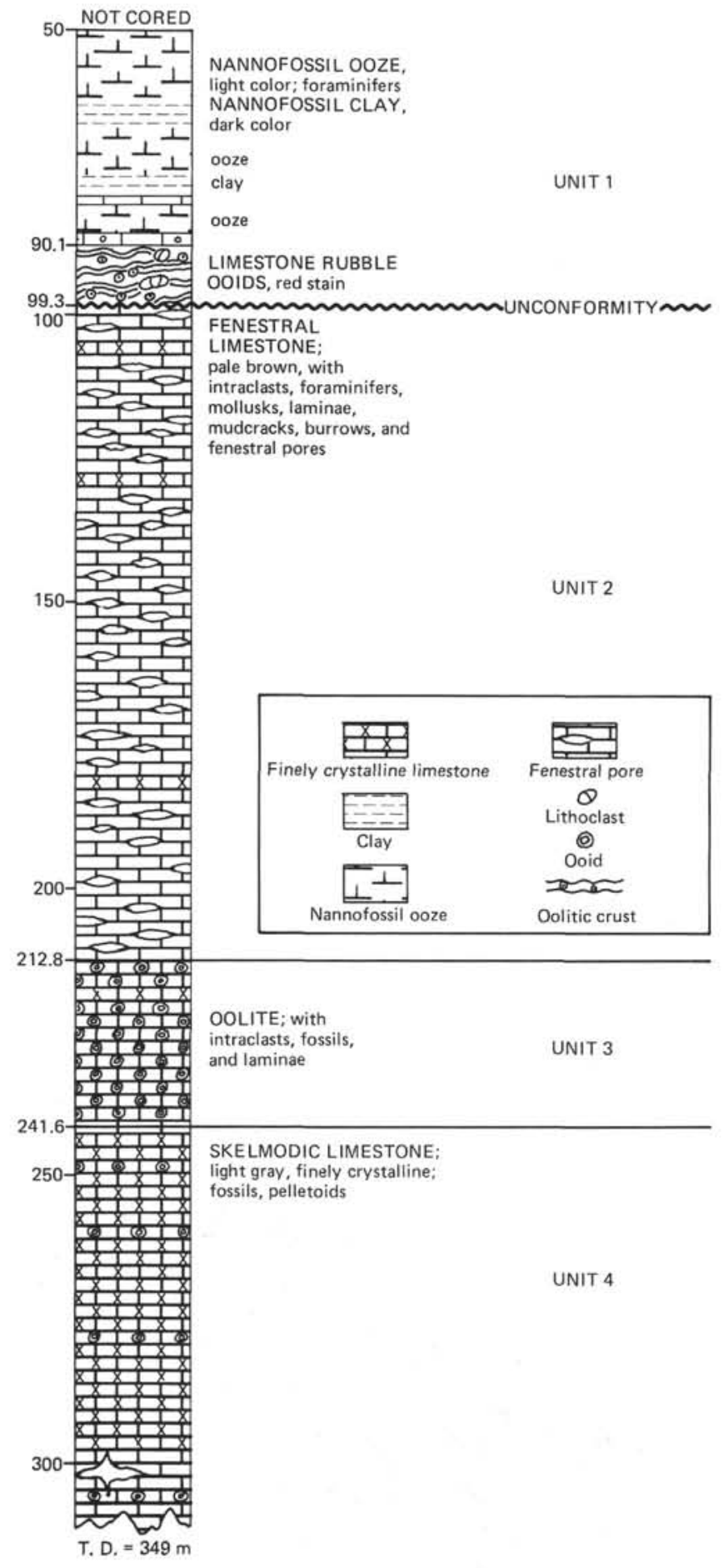

Figure 9. Summary of lithologic units, Site 392.

Toward the base, ooids with multiple concentric coatings predominate. Broken ooids are prominent at the base of the unit $(240 \mathrm{~m})$. Identifiable fossils are not abundant, but are present throughout. Fossils include green algae, small benthic foraminifers, robust clams, a few coral fragments, an encrusting bryozoan, and a cemented burrow lining, in addition to the omnipresent miliolids and gastropods. An important element is a codiacean green algae (Figure 11), abundant in several layers.

Sedimentary structures include lamination and alternating coarse-fine layering; we did not detect inclined lamination.
Small-scale erosional scour is common; some penecontemporaneous cementation is indicated by grains that were truncated by the erosion surface. Cemented oolite intraclasts occur in unit 3 and near the base of overlying unit 2.

Initial porosity of this sediment was high because of the mud-free texture (30\%-40\% with normal packing) and the shelter pores provided by large intraclasts and fossils. Sheet cracks and small vugs were formed early in the diagenetic sequence. Virtually all porosity has been occluded by a combination of diagenetic sediment and cement (Figure 12). In a few samples the diagenetic sediment consists of uneven coatings on grains, forming narrow "necks" connecting grains (meniscus sediment). Pendants of early cement occur on the undersides of grains or the roofs of sheet cracks (Figure 12). Both meniscus sediment and pendant cement are indicative of pore occlusion in a two-fluid-phase system - air and water (i.e., the vadose zone). Previously known examples of meniscus sediment are restricted to Pleistocene and younger rocks, and only two examples of pendant cement have been reported (by Freeman, from the Ordovian of Arkansas, and Purser, Jurassic of France).

Unit 3 is oolite throughout except for a few beds of finely crystalline limestone like that of unit 4 .

\section{Unit 4 - Skelmoldic Limestone (241.6-335.5 m)}

Limestone of unit 4 is characterized primarily by diagenetic homogeneity that partially obscures depositional textures and composition. The texture of the white (10YR $8 / 2$ ) or very pale brown (10YR $8 / 3$ ) limestone is finely crystalline or "sucrosic," generally with skeletal molds. Solution-enlarged intergranular porosity and vugs are also common. Despite some growth of spar in large vugs, present porosity ranges up to 40 per cent; 5 per cent is common. Sudden increases in drilling rate and drops of the drill bit from 293 to 393 meters and from 322 to 326 meters indicates the presence of zones of cavernous porosity at least 10 meters thick in the lower part of the interval penetrated. Large connected vugs in a piece of rock from the core-catcher sample at 296 meters support this interpretation.

The original lithology of unit 4 was probably somewhat varied, although this is readily visible only near the top of the unit where diagenetic effects were less severe. Elsewhere it is largely obscured by the diagenetic overprint. The dominant components appear to have been hard pelletoids, miliolids, and gastropods with few intraclasts and little or no interstitial lime mud. The biota was varied although not lush. In addition to the dominant miliolids and gastropods, it includes dasyclad and codiacean green algae (Figure 11), small benthic foraminifers, pelecypods, and branching corals(?). A cemented burrow lining is also present. Gastropods and dasyclad algae are the usual victims of skeletal mold formation.

Interbedded lithologies, indicated by recovery of isolated pieces, are oolite and, rarely, fenestral limestone. Because of poor recovery little can be said about the stratigraphic sequence of unit 4 .

\section{Interpretation}

We present a "simplest case" depositional cycle for Site 392 followed by consideration of some secondary diagenetic features. 


\begin{tabular}{|c|c|c|c|c|c|c|c|c|c|c|c|c|c|c|c|c|c|c|c|c|c|c|c|c|c|c|}
\hline \multirow{3}{*}{ 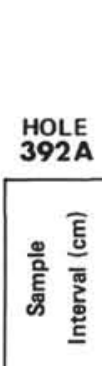 } & \multicolumn{7}{|c|}{ SMEAR SLIDE SUMMARY } & \multicolumn{10}{|c|}{ SITE $\underline{392}$} & \multicolumn{3}{|c|}{ KEY } & \multicolumn{3}{|c|}{\begin{tabular}{|l} 
TRACE \\
RARE \\
PAREENT \\
PEOMMON \\
CBUNDANT \\
ABMINANT \\
DO
\end{tabular}} & \multicolumn{2}{|c|}{$\begin{array}{l}t \\
<5 \\
5.24 \\
25.49 \\
50.74 \\
75.100 \\
\end{array}$} & \multirow[b]{3}{*}{ 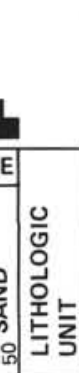 } \\
\hline & \multicolumn{6}{|c|}{ EXOGENIC } & & \multicolumn{9}{|c|}{ AUTHIGENIC-DIAGENIC } & \multicolumn{7}{|c|}{ BIOGENIC } & \multicolumn{2}{|c|}{ TEXTURE } & \\
\hline & 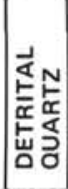 & 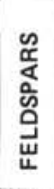 & 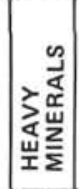 & 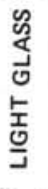 & 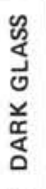 & $\underset{\mathrm{J}}{\mathrm{\delta}}$ & 点 & 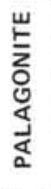 & 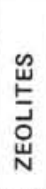 & 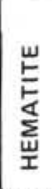 & 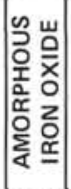 & 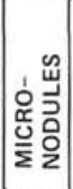 & $\frac{w}{\frac{w}{x}}$ & 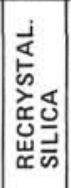 & 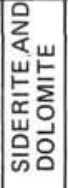 & 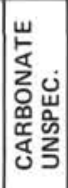 & 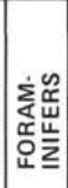 & 造出 & 资 & $\begin{array}{l}\sum_{0}^{\infty} \\
\frac{1}{\Delta} \\
\frac{\Delta}{0}\end{array}$ & 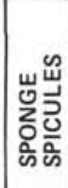 & 工 & 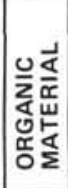 & 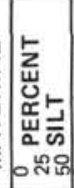 & 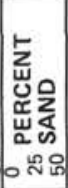 & \\
\hline $1-1,97$ & & & & & & & & & & & & & & & & & & & & & & & & & & \\
\hline $1-1,105$ & & & & & & & & & & & & & & & & & & & & & & & & & & \\
\hline $1-1,138$ & & & & & & & & & & & & & & & & & & & & & & & & & & \\
\hline $1-2,30$ & & & & & & & & & & & & & & & & & & & & & & & & & & \\
\hline $1-2,111$ & & & & & & & & & & & & & & & & & & & & & & & & & & \\
\hline $2-1,85$ & & & & & & & & & & & & & & & & & & & & & & & & & & \\
\hline $2-1,110$ & & & & & & & & & & & & & & & & & & & & & & & & & & \\
\hline $2-1,128$ & & & & & & & & & & & & & & & & & & & & & & & & & & \\
\hline $2-2,119$ & & & & & & & & & & & & & & & & & & & & & & & & & & \\
\hline $3-2,85$ & & & & & & & & & & & & & & & & & & & & & & & & & & \\
\hline $3-2,135$ & & & & & & & & & & & & & & & & & & & & & & & & & & \\
\hline $3-3,21$ & & & & & & & & & & & & & & & & & & & & & & & & & & \\
\hline $3-3,136$ & & & & & & & & & & & & & & & & & & & & & & & & & & \\
\hline $3-3,142$ & & & & & & & & & & & & & & & & & & & & & & & & & & \\
\hline
\end{tabular}

Figure 10. Estimate of major components in dominant and minor lithologies, Site 392.

Unit 1 represents pelagic accumulation with several minor influxes of terrigenous material, dominantly clay. The apparent hiatus between Campanian and lower Albian seems to be within an uncored interval but the sediments above and below are not appreciably different. Although intervals of dark nannofossil clay are confined to the Albian-Barremian sediments, the predominant oozes of those stages are lithologically indistinguishable from those of the Campanian.

Although comparison with the age-equivalent sediments recovered from Site 390 , only $25 \mathrm{~km}$ away on the northern part of the Blake Nose, is hampered by intermittent coring and drilling disturbances in some cores, some differences are immediately obvious. The Barremian to Campanian section is thicker at Site $392(40 \mathrm{~m}$ vs. $24 \mathrm{~m})$, although the top of the Campanian was not cored here, and the entire post-limestone section is only about half as thick ( $90 \mathrm{~m}$ vs. $161 \mathrm{~m}$ ). The distinctive variegated (brown, red, and white), firm marly nannofossil ooze which constitutes the entire Barremian through Albian section at Site 390 is not present at all at Site 392. Conversely, the ammonite limestone is not present at Site 390. In view of the continental margin setting of the Blake Nose and of the complexities indicated by seismic stratigraphy between the two sites, some variation is probable, although we would expect better local continuity of the pelagic or hemipelagic sediment (cf. suggested correlations for western North Atlantic basin (Lancelot et al., 1972).

The origin of the red limestone rubble and the associated goethite ooids and crusts at the base of unit 1 were the subject of debate onboard ship. The alternative hypotheses were (1) soil formation upon subaerial exposure of the underlying limestone and (2) formation by submarine weathering of an erosional surface without appreciable sediment accumulation during submergence, prior to the onset of pelagic sedimentation. The subaerial hypothesis was favored on the basis of shipboard examination, but later discovery of coccoliths within ooids, crusts, and altered lithoclasts suggests a submarine origin of these features.

The fenestral limestone of unit 2 was probably deposited on a tidal flat. The features on which we base this interpretation are outlined in Table 4. Oolite sedimentation, unit 3 , indicates deposition in shallow water, a high degree of supersaturation relative to calcium carbonate (normally aragonite), and highly agitated conditions. These conditions commonly occur at shelf breaks where oceanic water is focused into strong currents. We infer for unit four open or slightly restricted shelf depositional conditions because of the well-washed sediment, hardened pelletoids, and reasonably diverse, although not lush, biota. A modern analog is the pelletoidal sand environment which covers vast areas of the Great Bahama Banks, including somewhat deeper $(>10 \mathrm{~m})$ bank margins where ooid shoals, reefs, and islands are lacking. Some degree of restriction might be inferred from the few muddy and fenestral limestone intervals and from the lack of certain faunal elements (e.g., large benthic foraminifers) common to open shelf communities.

The limestone units taken as a group could have been deposited in a single sequence of regression or vertical accretion relative to sea level (Figure 13). The accretionary processes outlined could produce the elevated lip detected seismically at the edge of the Blake Nose. In the final stage the local area was emergent and caverns were developed such as those drilled in unit 4 . At this time the entire 250-meter limestone section cored at Site 392 was probably subjected to the diagenetic effects of fresh-water circulation, suggesting that the water table was some 6 meters above sea level. ${ }^{3}$

\footnotetext{
${ }^{3}$ In rocks capable of maintaining a fresh-water lens, the ratio between elevation of the water table above sea level and depression of the freshwater/salt-water beneath the lens (a function of the density contrast between the waters) is about 1:40.
} 
TABLE 3

Constituent Particle Composition of Unit 1 Average Percentages (standard deviation shown in parentheses), Adjusted to Carbonate "Bomb" analyses

\begin{tabular}{|c|c|c|c|c|c|c|c|}
\hline Lithology & Clay & Quartz & Mica & Carbonate Unspecified & Nannofossils & Foraminifers & Siliceous Fossils \\
\hline $\begin{array}{l}\text { Nannofossil ooze } \\
\text { ( } 9 \text { samples) }\end{array}$ & $\begin{array}{l}12 \\
(9)\end{array}$ & $\begin{array}{c}1 \\
(1)\end{array}$ & $\begin{array}{c}1 \\
(1)\end{array}$ & $\begin{array}{c}16 \\
(11)\end{array}$ & $\begin{array}{l}65 \\
(12)\end{array}$ & $\begin{array}{c}5 \\
(7)\end{array}$ & - \\
\hline $\begin{array}{c}\text { Clay and marly } \\
\text { ooze } \\
\text { (4 samples) }\end{array}$ & 42 & 10 & 5 & 7 & 7 & 27 & - \\
\hline
\end{tabular}

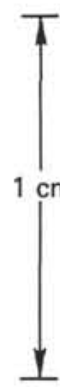
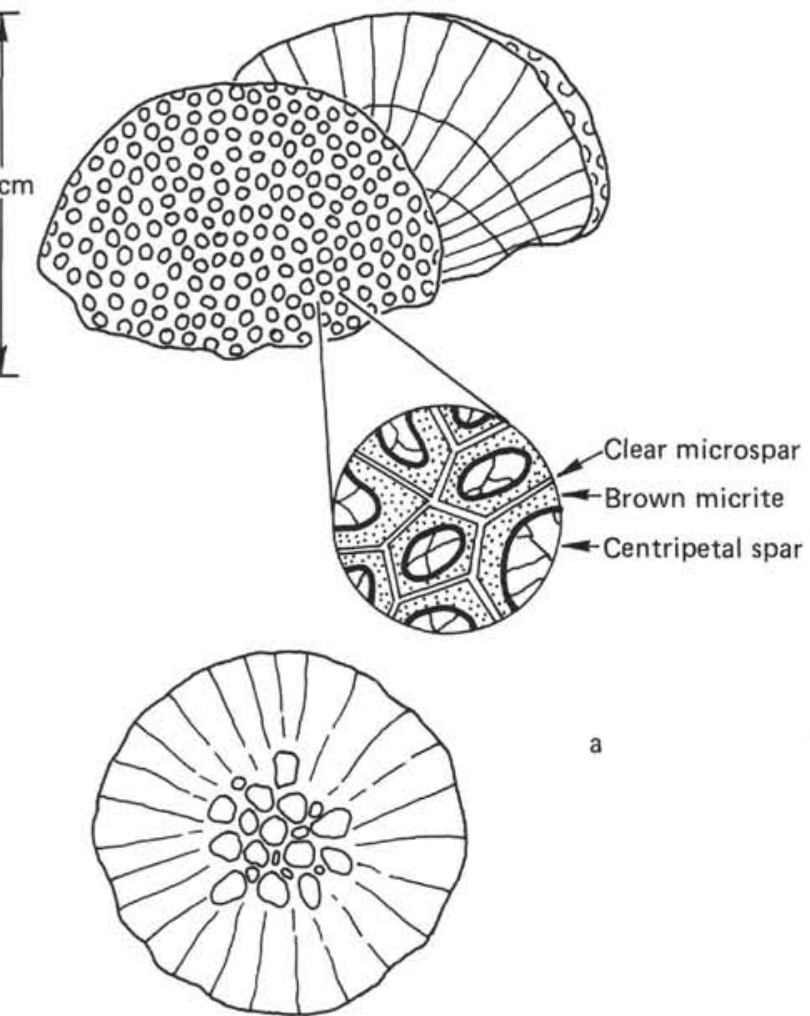

Horizontal section

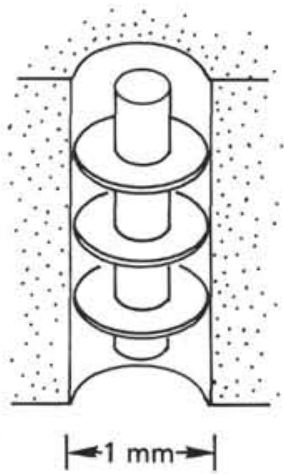

b

Figure 11. Common fossils found at Site 392 (a) codiacian green algae cf. Cayeuxia, especially abundant in unit 3 oolite; (b) dasyclad green algae is abundant as molds in unit 4 , skelmoldic limestone.

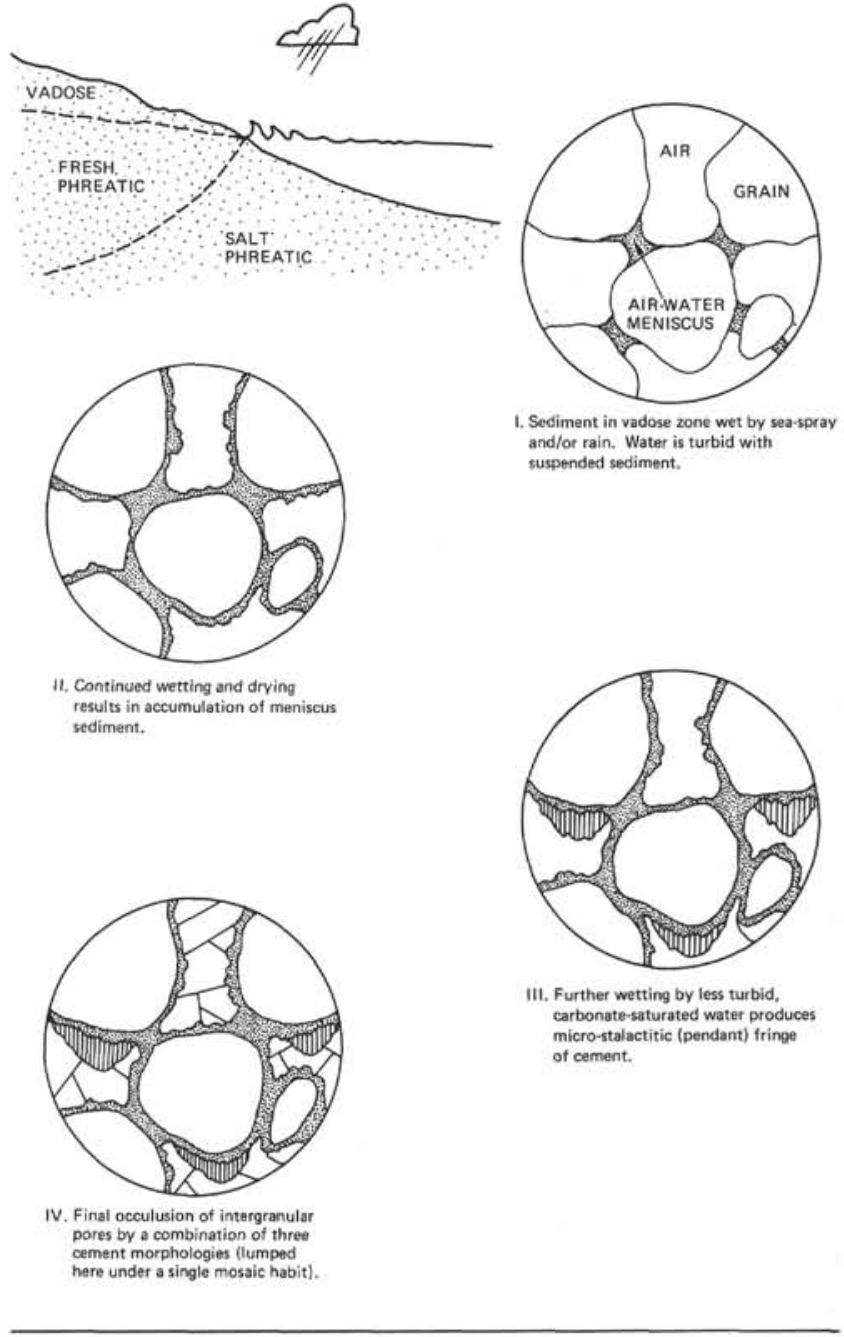

Figure 12. Meniscus sediment and micro-stalagtitic (pendant) cement attests to periodic vadose conditions.

The model outlined does not require pre-existing relief at the shelf edge. If relief is deemed necessary to account for some restriction of circulation in unit 4 it could have been provided by a number of non-tectonic developments such as (1) a discontinuous reef barrier, (2) relief inherited from an earlier cycle of deposition (a modern example is the Pleistocene eolianite ridges which rim the Bahama Banks), or (3) constructional topography from oolite shoals or shelf-margin skeletal sands. The coexistence of oolite shoals during deposition of unit 4 is indicated by oolite 
TABLE 4

Sedimentary Features of Unit 2, Fenestral Limestone, Indicative of Processes Active in Tidal Flat Sedimentation.

\begin{tabular}{ll}
\hline \multicolumn{1}{c}{ Feature } & \multicolumn{1}{c}{ Process } \\
\hline Lamination & $\begin{array}{l}\text { Periodic sedimentation, "punctuation" } \\
\text { by algae mats } \\
\text { Very thin micrograded laminae }\end{array}$ \\
$\begin{array}{l}\text { Periodic sedimentation by sheet } \\
\text { flooding at high tide } \\
\text { Desiccation }\end{array}$ \\
Crumb texture & $\begin{array}{l}\text { Desiccation } \\
\text { Desiccation and sheet flooding } \\
\text { Abundant soft intraclasts }\end{array}$ \\
$\begin{array}{l}\text { Fenestral porosity } \\
\text { Impoverished fauna, low species } \\
\text { diversity }\end{array}$ & $\begin{array}{l}\text { Environmental stress: variable } \\
\text { salinity, desiccation, variable } \\
\text { currents, periodic exposure }\end{array}$ \\
\hline
\end{tabular}

Note: The processes indicated are not the only possibilities, but are consistent with an overall interpretation of tidal sedimentation for unit 2 . intraclasts and oolite interbeds at Site 392. The presence of reefs is suggested by coral fragments in units $2-4$, but they are very rare except in the red limestone rubble. Moreover, traces of rudists, the most common Lower Cretaceous reef builders, are virtually absent. The codiacean green algae (Figure 11) could conceivably have been reef formers, but they are also prominent members of level-bottom communities.

An important second-order cycle is suggested by the cavernous porosity encountered in unit 4 . The scale of these features requires extensive exposure to meteoric water. This could have been accomplished by fresh-water circulation in at least the lower part of unit 4 before it was covered by younger rocks. Thus the single cycle outlined in Figure 13 may have begun following exposure of the basal part of unit 4 (e.g., below 293 m sub-bottom). Poor recovery from unit 4 precludes identity of any surface of subaerial exposure

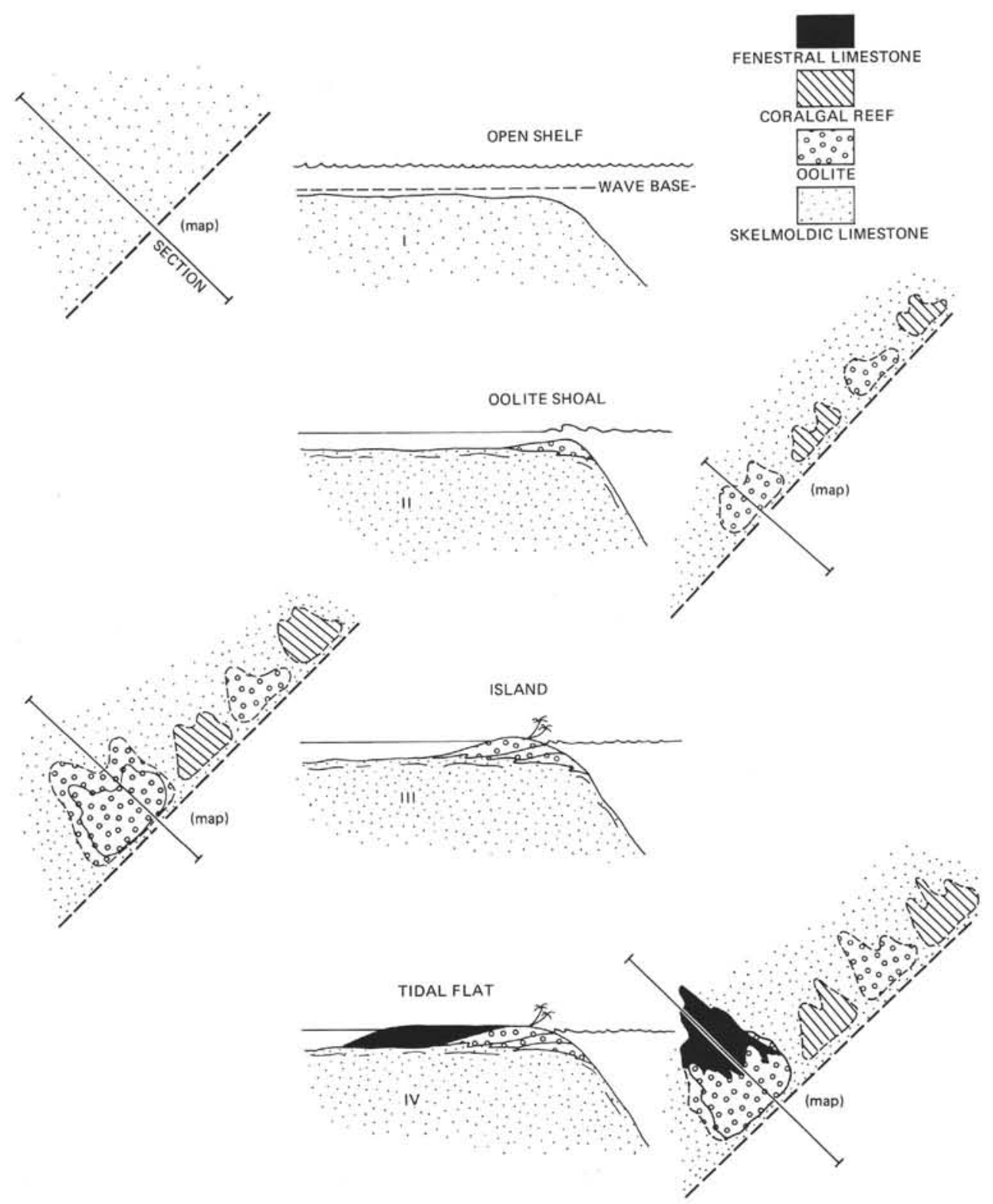

Figure 13. Detail of facies succession, Site 392. Coral-algal reef is inferred from traces in associated rocks. 
that might be related to early cavern formation, but erosional features interpreted as microkarst formation were recovered in a rock from 265 meters sub-bottom. No exposure surface is present at the contact between units 3 and 4 . In fact, the upper part of unit 4 has suffered less diagenetic overprint than lower portions, which would be consistent with earlier exposure of the lower portion.

Periodic exposure may have occurred during deposition of the oolite. Erosional surfaces with truncated grains and the occurrence of cemented oolite intraclasts point to early cementation. The lack of biological erosion (e.g., borings) or encrustation associated with the erosion surfaces suggests subaerial rather than submarine cementation. The formation of the meniscus and dripstone cements (Figure 12) probably required subaerial exposure.

Despite the regressive (upward shoaling) nature of the sedimentary cycle at Site 392 , the net relative movement of the entire shelf during this period was probably downward. This is necessary to account for the accumulation of more than 250 meters of shallow-water limestone, the top 123 meters of which are peritidal. Limestone could have been continuously deposited under shallow-water conditions as the system is basically self-regulating. Given reasonable conditions for the production of skeletons, the raw materials for most carbonate rocks, carbonate shelf margins can potentially accrete vertically in pace with all but the most rapid rises of sea level. This accretion rate cannot, of course, exceed the subsidence rate or the shelf accretes to sea level and the carbonate factory is temporarily closed.

Subaerial exposure following deposition of fenestral limestone (unit 2) marks the cessation of shallow-water sedimentation on the Blake Nose. Although this event is not yet well dated, on the basis of the general aspect of the fossils it is probably no older than Neocomian. Inasmuch as pelagic sediments were deposited immediately above the eroded limestone surface, extremely rapid subsidence or relative sea-level rise during the Barremian must simply have submerged the Blake Nose below the very shallow depths necessary for rapid carbonate production. This "drowning" was geologically rapid as no shallow-water carbonate accumulated following exposure. Currents may have prevented deposition over the eroded surface until Barremian pelagic sediments began to accumulate.

\section{GEOCHEMISTRY}

We analyzed only one interstitial water sample from this site to determine $\mathrm{pH}$, alkalinity, chlorinity, salinity, and major cations (Table 5). We did not collect samples for study of organic geochemistry because the sediment is mainly white limestone. No gas was detected in cores from this site.

\section{PHYSICAL PROPERTIES}

We drilled two holes at Site 392 . Hole 392 was terminated at 60 meters sub-bottom when we found that there was insufficient soft sediment cover to properly bury the bottom-hole assembly. Hole 392A was drilled to a sub-bottom depth of 349 meters through 99 meters of soft Cretaceous calcareous ooze and 251 meters of dense, hard limestone.

Sonic velocity, water content, porosity, and wet bulk density were determined for samples from Hole 392A; data are compiled on Tables 6 and 7. Core recovery, however, was very poor (only $9 \%$ ) and soft interbedded sediments may have been washed away during drilling, hence the physical properties data may not be representative of the entire sequence.

We recognized four lithologic units at this site and average values for the physical properties data for each unit are given in Table 8.

\section{Sonic Velocity and Impedance}

Sonic velocities were measured on 24 samples using the Hamilton Frame velocimeter following the procedure described by Boyce (1973). Accuracy of the technique is \pm 2 per cent, and precision of the velocimeter was verified with 10 repeated measurements of lucite and brass standards. Velocities were measured parallel to bedding in the upper four cores of calcareous and marly ooze. In the few cases where orientation was preserved in the hard limestones velocities were measured perpendicular to bedding (Cores 5 and 6 , in part). Most of the limestone was recovered in chunks and pieces in which the original orientation was totally lost. Thus, direction of velocity measurements below Core 8 is not known.

We determined impedance at points where both velocity and density data were available (12 data points). Density was determined by the "syringe"' technique (Cores 1-4) and the "chunk" technique described in Site 391 Physical Properties report. The average velocity and impedance for each lithologic unit are given in Table 8.

We have insufficient data points to speculate on trends within the three limestone units (only a total of three data points for velocity in units 3 and 4). A very marked velocity and impedance "break" occurs between the soft nannofossil ooze and clay of unit $1(1.67 \mathrm{~km} / \mathrm{sec} ; 2.43$ $\left.\mathrm{gm} / \mathrm{cm}^{2} \mathrm{sec} \times 10^{5}\right)$ and dense limestones of unit $2(5.85$ $\left.\mathrm{km} / \mathrm{sec} ; 16.2 \mathrm{gm} / \mathrm{cm}^{2} \mathrm{sec} \times 10^{5}\right)$. This corresponds to a prominent reflector at $0.115 \mathrm{sec}$.

Velocity and impedance measurements on Cretaceous limestones from lithologic units 2,3 , and 4 are exceptionally high (velocity ave. $=5.55 \mathrm{~km} / \mathrm{sec}$,

TABLE 5

Summary of Interstitial Water Data, Hole 392A

\begin{tabular}{ccccccrr}
\hline Sample & $\begin{array}{c}\text { Sub-Bottom Depth } \\
\text { Top }(\mathrm{m})\end{array}$ & $\mathrm{pH}$ & $\begin{array}{c}\text { Alkalinity } \\
(\mathrm{meg} / \mathrm{kg})\end{array}$ & $\begin{array}{c}\text { Salinity } \\
(0 / 00)\end{array}$ & $\begin{array}{c}\mathrm{Ca}^{++} \\
(\mathrm{m} \mathrm{Moles} / \mathrm{l})\end{array}$ & $\begin{array}{c}\mathrm{mg}^{++} \\
(\mathrm{m} \mathrm{Moles} / \mathrm{l})\end{array}$ & $\begin{array}{c}\mathrm{Cl}^{-} \\
(0 / 00)\end{array}$ \\
\hline IAPSO STD Seawater & - & 7.87 & 2.36 & 35.2 & 10.55 & 53.99 & 19.38 \\
Surface Seawater & - & 8.41 & 2.41 & 36.3 & 10.88 & 59.41 & 19.77 \\
392A-3-4, 140-150m & 82.2 & 7.58 & 2.61 & 36.3 & 10.71 & 52.19 & 19.90 \\
\hline
\end{tabular}


TABLE 6

Sonic Velocity Measurements, Hole 392A

\begin{tabular}{|c|c|c|c|c|c|}
\hline $\begin{array}{c}\text { Sample } \\
\text { (Interval in cm) }\end{array}$ & $\begin{array}{l}\text { Depth in } \\
\text { Hole }(\mathrm{m})\end{array}$ & $\begin{array}{l}\text { Velocity } \\
(\mathrm{km} / \mathrm{sec})\end{array}$ & $\begin{array}{c}\text { Impedance } \\
\left(\mathrm{g} / \mathrm{cm}^{2} \sec \times 10^{5}\right)\end{array}$ & $\begin{array}{l}\text { Lithologic } \\
\text { Unit }\end{array}$ & Lithology \\
\hline $1-2,76$ & 52.76 & 1.62 (in liner) & 2.56 & 1 & Foraminifer-nannofossil ooze \\
\hline $1-2,132$ & 53.32 & 1.65 (in liner) & & 1 & Foraminifer-nannofossil ooze \\
\hline $2-1,63$ & 66.63 & 1.61 (in liner) & 1.67 & 1 & Marly nannofossil ooze \\
\hline $3-2,107$ & 81.57 & 1.70 (in liner) & 3.25 & 1 & Nannofossil ooze \\
\hline $3-2,130$ & 81.80 & 1.72 (in liner) & & 1 & Nannofossil ooze \\
\hline $3-3,25$ & 82.25 & 1.70 (in liner) & & 1 & Nannofossil ooze \\
\hline $3-3,82$ & 82.82 & 1.68 (in liner) & 2.25 & 1 & Nannofossil ooze \\
\hline $3-3,135$ & 83.35 & 1.69 (in liner) & & 1 & Nannofossil ooze \\
\hline $5-1,144$ & 99.44 & $5.52^{\mathrm{a}}$ (out of liner) & & 2 & Fenestral lime mudstone \\
\hline $5-1,144$ & 99.44 & 5.87 (out of liner) & & 2 & Fenestral lime mudstone \\
\hline $5-2,47$ & 99.97 & $5.53^{\mathrm{a}}$ (out of liner) & & 2 & Intraclastic skeletal, lime packstone \\
\hline $5-2,47$ & 99.97 & 5.73 (out of liner) & & 2 & Intraclastic skeletal, lime packstone \\
\hline $6-1,129$ & 108.79 & $5.73^{\mathrm{a}}$ (out of liner) & 15.13 & 2 & Pelletoidal lime grainstone \\
\hline $6-1,129$ & 108.79 & 5.66 (out of liner & & 2 & Pelletoidal lime grainstone \\
\hline $8-1,140$ & 127.90 & 6.38 (out of liner) & 17.16 & 2 & Limestone \\
\hline $9-1,54$ & 136.54 & $5.70^{\mathrm{a}}$ (out of liner) & 15.22 & 2 & Limestone \\
\hline $10-2,141$ & 141.91 & $6.11^{\mathrm{a}}$ (out of liner) & & 2 & Lime mudstone \\
\hline $11-1,55$ & 146.05 & $5.52^{\mathrm{a}}$ (out of liner) & & 2 & Pelletoidal lime packstone \\
\hline $11-1,131$ & 146.81 & $5.98^{\mathrm{a}}$ (out of liner) & 15.97 & 2 & Pelletoidal lime packastone \\
\hline $16-1,144$ & 184.94 & $6.21^{\mathrm{a}}$ (out of liner) & 16.58 & 2 & Limestone \\
\hline $17-1,50$ & 193.50 & 6.07 (out of liner) & 16.27 & 2 & Lime packstone \\
\hline $21-1,119$ & 232.19 & 5.97 (out of liner) & 16.00 & 3 & Oolite-lime grainstone \\
\hline $22-1,109$ & 241.59 & 5199 (out of liner) & 15.93 & 3 & Oolite-lime grainstone \\
\hline $23-1,75$ & 250.75 & 4.72 (out of liner) & & 4 & Limestone \\
\hline
\end{tabular}

${ }^{\mathrm{a}}$ Measurements perpendicular to bedding.

TABLE 7

Water Content, Porosity, and Wet Bulk Density, Hole 392A

\begin{tabular}{lcccccl}
\hline $\begin{array}{c}\text { Sample } \\
\text { (Interval in cm) }\end{array}$ & $\begin{array}{c}\text { Depth in } \\
\text { Hole }(\mathrm{m})\end{array}$ & $\begin{array}{c}\text { Water Content } \\
(\%)\end{array}$ & $\begin{array}{c}\text { Wet Bulk Density } \\
(\mathrm{g} / \mathrm{cc})\end{array}$ & $\begin{array}{c}\text { Porosity } \\
(\%)\end{array}$ & $\begin{array}{c}\text { Lithologic } \\
\text { Unit }\end{array}$ & \multicolumn{1}{c}{ Lithology } \\
\hline $1-2,78.5$ & 52.79 & 24.0 & 1.58 & 38.0 & 1 & $\begin{array}{l}\text { Nannofossil ooze } \\
\text { Marly nannofossil ooze }\end{array}$ \\
$3-1,62.5$ & 66.63 & 27.5 & 1.04 & 28.5 & 1 & Marly nannofossil ooze \\
$3-3,82.5$ & 81.57 & 23.8 & 1.91 & 45.4 & 1 & Nannofossil ooze \\
$4-1,119.5$ & 82.83 & 19.3 & 1.34 & 25.9 & 1 & Nannofossil ooze \\
$5-2,114.0$ & 89.70 & 28.7 & 1.34 & 38.5 & 1 & Limestone \\
$6-1,129.0$ & 100.64 & 0.6 & 2.70 & 1.7 & 2 & Pelletoidal lime grainstone \\
$7-1,137.0$ & 108.79 & 1.7 & 2.64 & 4.5 & 2 & Lime packstone \\
$8-1,137.0$ & 127.37 & 1.2 & 2.67 & 3.1 & 2 & Limestone \\
$9-1,54.0$ & 136.54 & 0.7 & 2.69 & 2.3 & 2 & Lime mudstone \\
$10-2,26.0$ & 140.76 & 1.0 & 2.67 & 2.8 & 2 & Limestone \\
$11-1,131.0$ & 146.81 & 1.4 & 2.66 & 3.8 & 2 & Limestone \\
$15-1,134.0$ & 177.34 & 6.6 & 2.67 & 2.9 & 2 & Limestone \\
$16-1,147.0$ & 184.97 & 1.0 & 2.43 & 16.1 & 2 & Limestone \\
$17-1,50.0$ & 193.50 & 0.6 & 2.67 & 2.6 & 2 & Limestone \\
$19-1,132.0$ & 213.32 & 0.7 & 2.68 & 1.5 & 2 & Pelletoidal lime grainstone \\
$20-1,135.0$ & 222.85 & 0.7 & 2.68 & 1.9 & 2 & Oolite-lime grainstone \\
$21-1,118.0$ & 232.18 & 0.8 & 2.69 & 2.0 & 3 & Oolite-lime grainstone \\
$22-1,109.0$ & 241.59 & 1.1 & 2.68 & 2.1 & 3 & Oolite-lime grainstone \\
$23-1,106.0$ & 251.06 & 1.7 & 2.66 & 2.9 & 3 & Limestone \\
\hline
\end{tabular}

TABLE 8

Average Sonic Velocity, Water Content, Wet Bulk Density, and Porosity, Site 392

\begin{tabular}{|c|c|c|c|c|c|c|c|c|c|c|c|c|}
\hline $\begin{array}{c}\text { Lithologic } \\
\text { Unit }\end{array}$ & $\begin{array}{l}\text { Average } \\
\text { Velocity } \\
(\mathrm{km} / \mathrm{sec})\end{array}$ & $\begin{array}{c}\text { Range } \\
(\mathrm{km} / \mathrm{sec})\end{array}$ & $\begin{array}{l}\text { No. of } \\
\text { Measure- } \\
\text { ments }\end{array}$ & $\begin{array}{c}\text { Average } \\
\text { Water Content } \\
(\%)\end{array}$ & $\begin{array}{l}\text { Range } \\
(\%)\end{array}$ & $\begin{array}{l}\text { No. of } \\
\text { Measure- } \\
\text { ments }\end{array}$ & $\begin{array}{c}\text { Average Wet } \\
\text { Bulk Density } \\
(\mathrm{g} / \mathrm{cc})\end{array}$ & $\begin{array}{l}\text { Range } \\
(\mathrm{g} / \mathrm{cc})\end{array}$ & $\begin{array}{l}\text { No. of } \\
\text { Measure- } \\
\text { ments }\end{array}$ & $\begin{array}{c}\text { Average } \\
\text { Porosity } \\
(\%)\end{array}$ & $\begin{array}{l}\text { Range } \\
(\%)\end{array}$ & $\begin{array}{l}\text { No. of } \\
\text { Measure- } \\
\text { ments }\end{array}$ \\
\hline 1 & 1.67 & $1.61-1.72$ & 8 & 23.5 & $19.3-28.7$ & 5 & 1.44 & $1.04-1.91$ & 5 & 35.3 & $25.9-45.4$ & 5 \\
\hline 2 & 5.85 & $5.52 \cdot 6.38$ & 13 & 1.5 & $0.6-1.7$ & 11 & 2.65 & $2.43-2.70$ & 11 & 3.9 & $1.5-16.1$ & 11 \\
\hline 3 & 5.98 & $5.97-5.99$ & 2 & 0.9 & $0.7-1.1$ & 3 & 2.68 & $2.66-2.69$ & 3 & 2.3 & $2.0-2.9$ & 3 \\
\hline 4 & 4.72 & 4.72 & 1 & 1.7 & 1.7 & 1 & 2.65 & 2.65 & 1 & 4.6 & 4.6 & 1 \\
\hline
\end{tabular}


impedance $=16.03\left(\mathrm{~g} / \mathrm{cm}^{2} \times \mathrm{sec} \times 10^{5}\right)$ and are in general agreement with velocities assumed from seismic profiles $(5.0 \mathrm{~km} / \mathrm{sec})$.

\section{Water Content, Porosity, and Wet Bulk Density}

Procedures for determining water content, porosity and wet bulk density are discussed in the Site 391 report, this volume. Determinations were made on 20 samples from Hole 392A. Data are presented on Table 7 and average values for each of the four lithologic units are given in Table 8 . As would be expected there is a marked break in all three properties between sediments of unit 1 (soft ooze) and those of the underlying limestone. The limestone is quite dense $(2.43-2.68 \mathrm{~g} / \mathrm{cc})$ and generally has low porosities (0.6-1.1\%), which no doubt are responsible for the high velocities. Most original fenestral and shelter porosity has been filled with two generations of cement.

\section{GRAPE}

Measurements of wet bulk density and porosity were taken on samples of known dimensions with the Gamma Ray Attenuation Porosity Evaluator (GRAPE). Samples from Hole 392A below Core 4 were lithified rocks and could be removed from the liners allowing special two-minute counts to be made on selected samples, thereby diminishing the variation encountered by continuous scan. GRAPE data were collected on 15 sections in Hole 392A. GRAPE data are graphically presented with the visual core descriptions and core photographs at the end of this chapter.

\section{BIOSTRATIGRAPHY}

Site 392 is situated approximately $15 \mathrm{~km}$ south of Site 390 on the Blake Nose. The objectives of Holes 392 and 392A were to sample the reef-like limestones which nearly reach surface here. We drilled to a total sub-bottom depth of 349 meters and recovered 35 cores - two in Hole 392 and 33 in Hole 392A. (We did not recover sediment in Cores 32 and 33.) The water depth at Site 392 is 2601 meters, well above the CCD.

Well preserved foraminifers and nannofossils are common to abundant in the ooze above the hard limestone which allows detailed biostratigraphic determinations in Hole 392A.

In Hole 392, the two cores taken near the surface are a mixture of ooze, hard limestone, and manganese chips or pebbles. Quaternary, middle Eocene, and Upper Cretaceous nannofossils, and foraminifers are present. The limestone here is probably capped by a veneer of Cretaceous, Eocene, and Quaternary sediment with manganese pebbles and reworked fossils.

The biostratigraphic succession in Cores 1-4 in Hole $392 \mathrm{~A}$ of four nannofossil zones and six foraminifer zones resembles the succession in Hole 390, Cores 3 to 6 and $390 \mathrm{~A}$, Core 14 (Figure 14). The zones comprise upper Campanian, middle-upper Albian, upper Aptian, and Barremian sediments. Differences are that at Site 392 lower Aptian (-Barremian) beds were not recovered and younger Albian strata are present.

The hard limestone in Cores 392A-5 through 31 yielded only a sparse foraminifer assemblage, mainly miliolids; no larger foraminifers were found. The sediment is a very

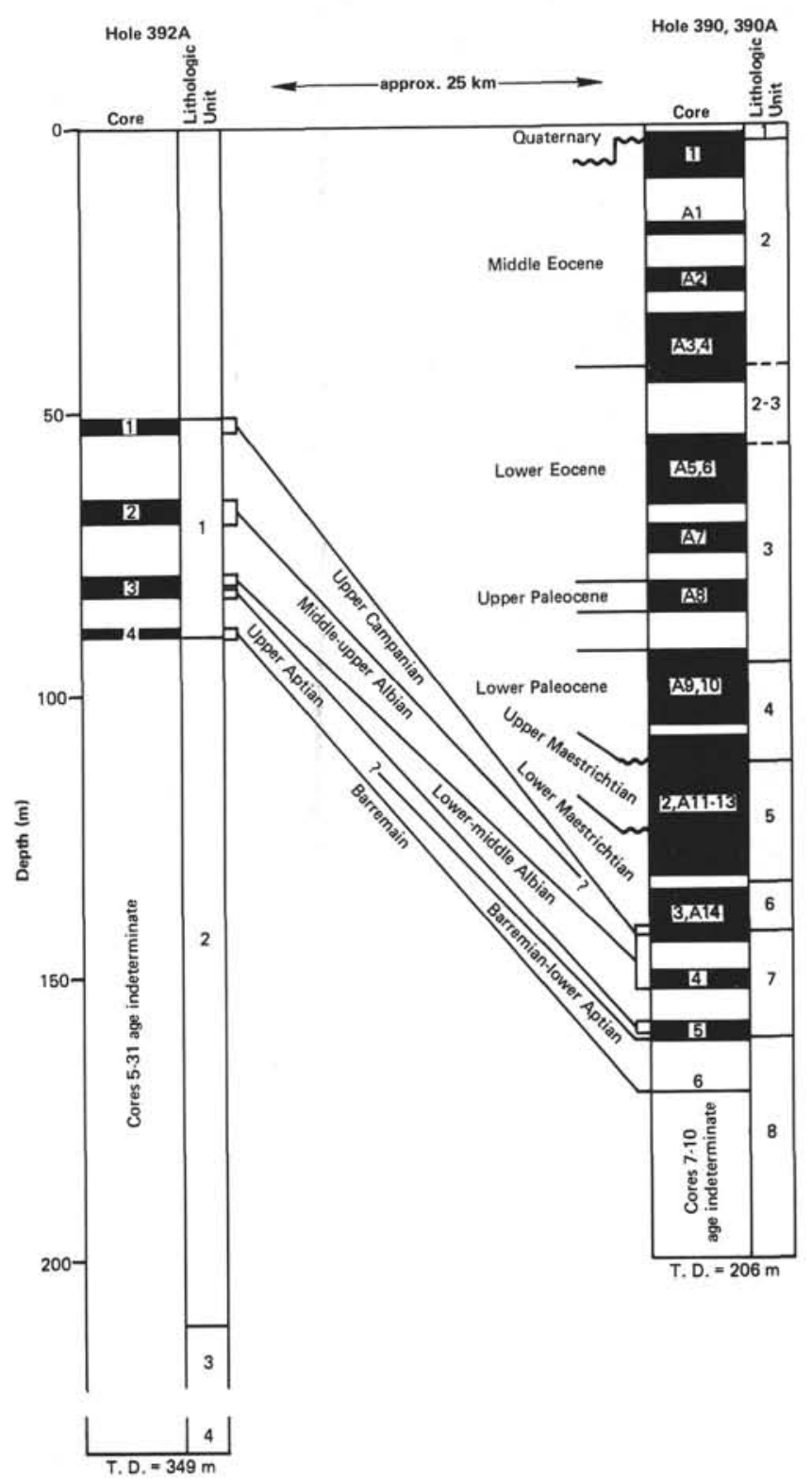

Figure 14. Chronostratigraphic correlation of Hole $392 \mathrm{~A}$ to Holes 390 and $390 \mathrm{~A}$.

shallow marine limestone of indeterminate age overlain by Barremian sediments. The Barremian deposits above are shallow-water limestone; the Aptian-Albian and upper Campanian ooze formed in a deeper, open marine environment.

\section{Foraminifers}

The two shallow cores taken from Hole 392 contain Quaternary, middle Eocene, and Upper Cretaceous foraminifers. Well preserved upper Campanian to Barremian foraminifers are common to abundant in Cores 392A-1 through 4 in nannofossil ooze and clay. Cores 5 to 31 , in hard limestone, have few foraminifers and none is age diagnostic. No sediment was recovered in Cores 32 and 33.

The biostratigraphy of Lower Cretaceous foraminifers at Site 392 differs from that of Site 390 in the absence of the 


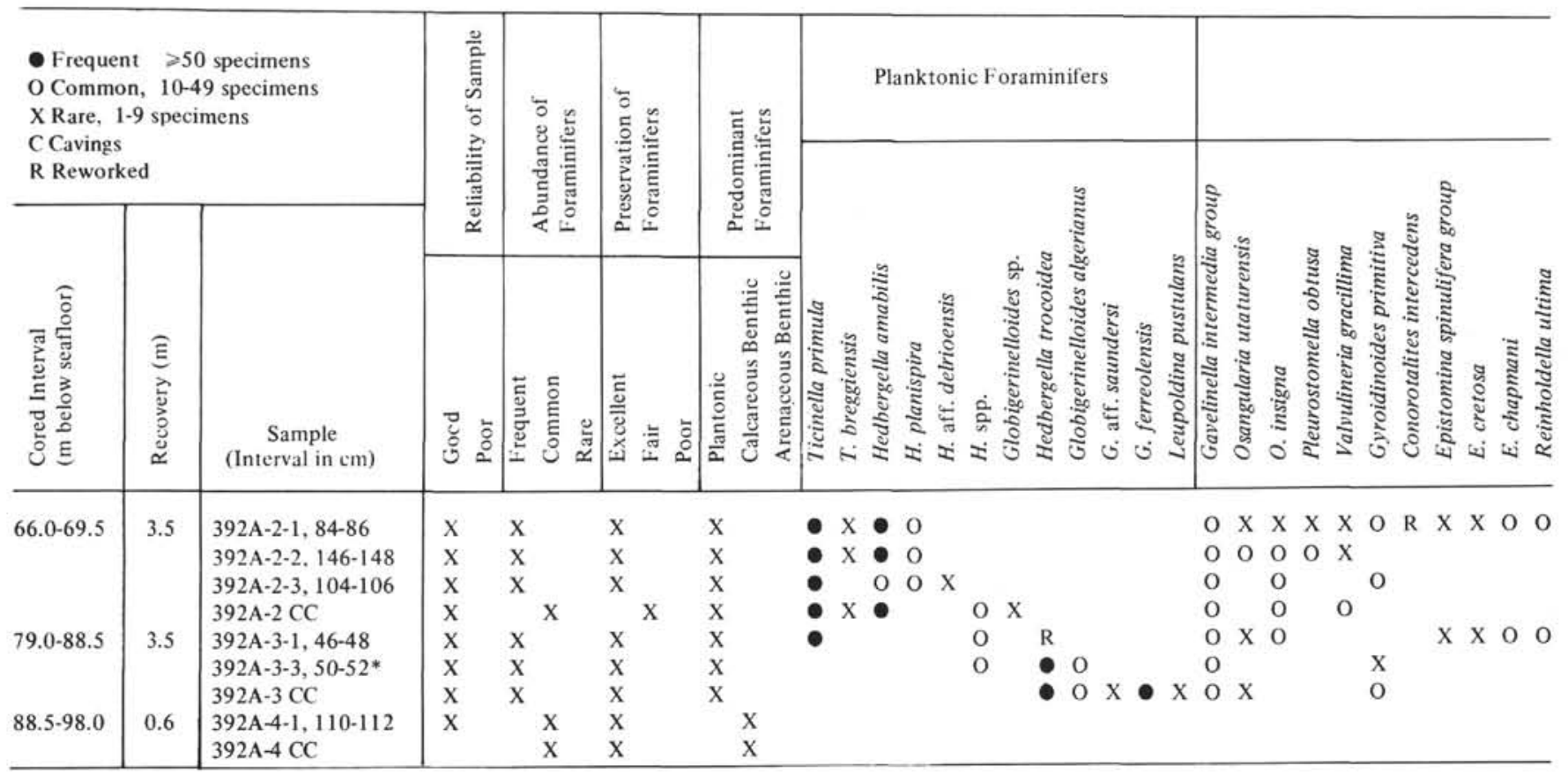

* 392A-3-2, 121-123 cm belongs in the same zone.

Figure 15. Distribution and correlation of Lower Cretaceous foraminifers in Site 392.

lower Aptian G. blowi Zone, the possible presence of the upper Aptian $S$. cabri Zone, and the presence of the upper Albian T. breggiensis Zone. The stratigraphic ranges of the Lower Cretaceous foraminifers are shown on Figure 15 and details of the Lower Cretaceous foraminifer biostratigraphy (Sites 392 and 390) are given in Gradstein, this volume.

\section{Upper Cretaceous}

Sample 392A-1, CC: Globotruncana calcarata Zone, (UC11) upper Campanian

The core-catcher sample of Core $1(50.5-53.2 \mathrm{~m})$ contains Globotruncana calcarata, $G$. fornicata, $G$. linneiana group, $G$. marginata, $G$. aff. arca, $G$. stuartiformis, $G$. ventricosa, $G$. aff. Gagnebini, Rugoglobigerina rugosa, and various hedbergellids and Heterohelicids. Benthic foraminifers are very sparse. A comparable assemblage, also belonging in the upper Campanian G. calcarata Zone, occurs in Hole 390A, Core 14-5.

\section{Cretaceous}

Samples 392A-2-1, 84-86 cm; 2-2, 146-148 cm; 2-3, 104-106 cm; 2, CC: Ticinella breggiensis Zone (LC17), upper Albian

Ticinella primula, T. breggiensis, ${ }^{*}$ Hedbergella amabilis, ${ }^{*} H$. planispira, $H$. aff. delrioensis, Gavelinella intermedia group, Osangularia utaturensis, $O$. insigna, Pleurostomella obtusa, Valvulineria gracillima, Gyroidinoides primitiva, Epistomina spinulifera group, $E$. cretosa, * E. chapmani, * Reinholdella ultima, * Orthokarstenia shastaensis, * Dentaline debilis, * Lingulina loryi,* Lingogavelinella ciryi,* Dorothia gradata, D. oxycona. ${ }^{4}$

\footnotetext{
${ }^{4}$ Species marked with an asterisk were not found in the Albian sediments of Site 390 (Ticinella primula Zone).
}

Sample 392A-3-1, 46-48 cm: Ticinella primula Zone (LC15-16), middle Albian

Ticinella primula, Gavelinella intermedia group, Osangularia utaturensis, O. insigna, Epistomina spinulifera group, E. cretosa, E. chapmani, Reinholdella ultima, Orthokarstenia shastaensis, Lingogavelinella ciryi, Lamarckina lamplughi, Ceratolamarckina sp., Dorothia oxycona, Gaudryina dividens group.

This assemblage differs from the immediately overlying one ( $T$. breggiensis Zone) in the absence of Ticinella breggiensis, Hedbergella amabilis, and $H$. planispira and the presence of Lamarckina lamplughi and Ceratolamarckina sp. At Site 390 Hedbergella planispira occurs commonly in the $T$. primula Zone.

Sample 392A-3-3, 50-52 cm: Globigerinelloides algerianus Zone (LC11), upper Aptian

Hedbergella trocoidea, Globigerinelloides algerianus, Conorotalites aptiensis, Lenticulina turgidula, $L$. vocontiana, Dorothia gradata, Gaudryina dividens group, Gavelinella intermedia group.

Sample 392A-3, CC: Schackoina cabri-Globigerinelloides algerianus Zone (LC10-11), upper Aptian

Same as in Sample 392A-3-3, 50-52 cm and also Globigerinelloides aff. saundersi, G. ferreolensis, and Leupoldina pustulans which are restricted to this sample.

Sample 392A-4-1, 110-112 cm; 4, CC: Gavelinella barremiana-Lenticulina (Marginulopsis) sigali assemblage (LC8, pp) Barremian

Conorotalites aptiensis, Gavelinella barremiana, Lenticulina ouachensis group, $L$. meridiana, $L$. (Marginulopsis) sigali, L. nodosa, Trocholina sp.

The exclusively benthic assemblage correlates to 390-6-1 (slurry) and 390-6, CC where it is more diversified in 


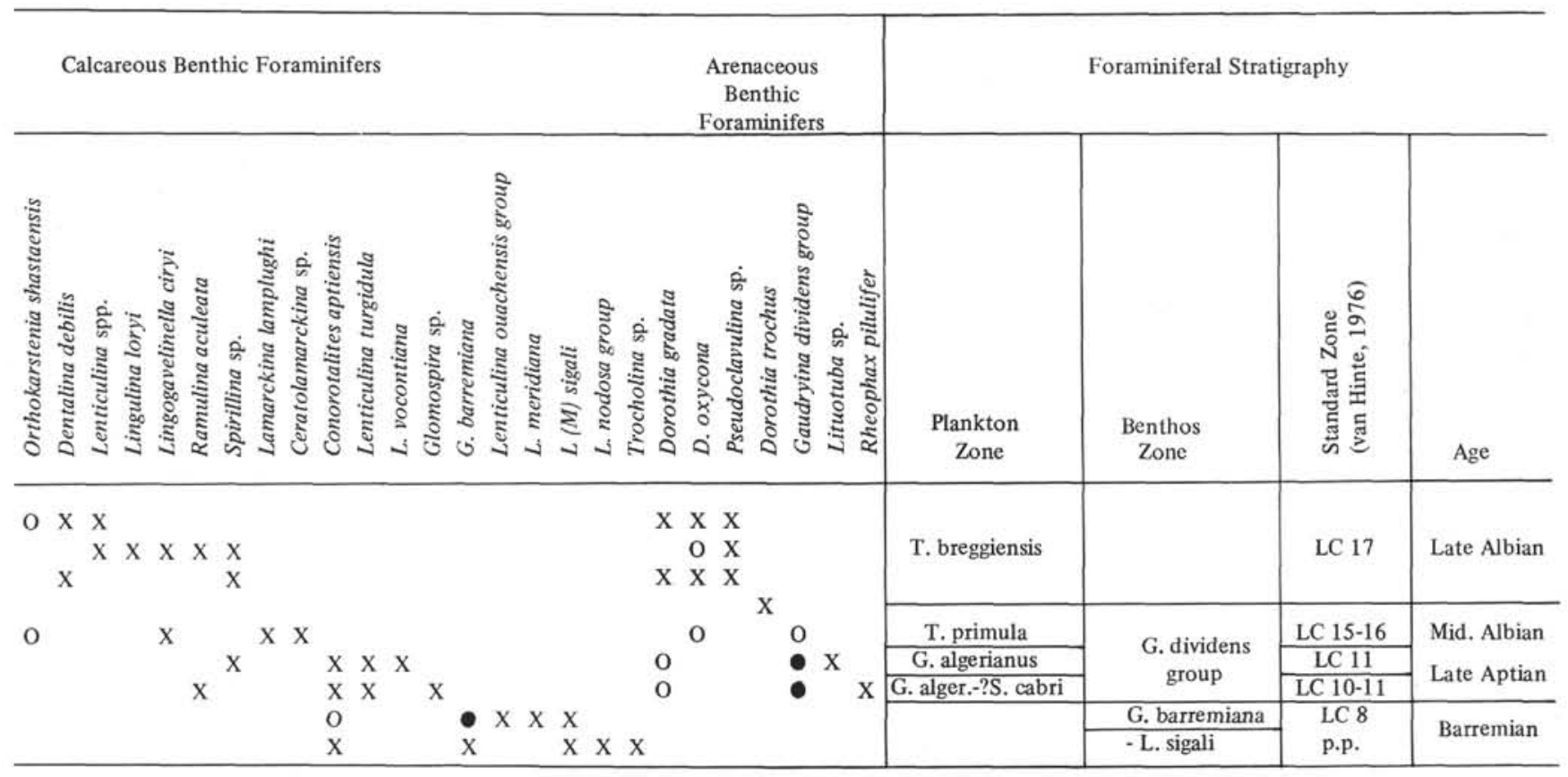

Figure 15. Continued.

species and includes "Globigerina" hoterivica (in 390-6, $\mathrm{CC}$, Epistomina spp., Conorotalites intercedens (in 6, $\mathrm{CC}$ ), and Lenticulina crepidularis (in 6, CC).

Cores 392A-5-31: age indeterminate

Miliolids are common in Cores 5 through 31 in addition to a few simple arenaceous and/or calcareous benthic foraminifers of indeterminate age.

\section{Nannoplankton}

Manganiferous sediment and ooze containing upper Quaternary, middle Eocene, and Cretaceous sediment was recovered as drilling breccia in the two cores of Hole 392. Core $392-2$ is questionably assigned to the combined Gephyrocapsa oceanica/Emiliania huxleyi zonal interval (NN 20/21), although drilling may have mixed the oozes.

In Hole 392A, the uppermost four cores contain upper Campanian and Albian-Barremian nannofossil oozes in which well preserved nannofossils are common to abundant. The nannofossil biostratigraphy of the Cretaceous ooze of Hole 392A is comparable to Hole 390A in which an Albian/upper Campanian hiatus is also present.

An abundant and well preserved flora of the Tetralithus (upper Campanian) trifidus Zone was recovered from Core 392A-1. Core 392A-2 contains a flora of the early-middle Albian Prediscosphaera cretacea Zone. Core $392 \mathrm{~A}-3$ is assigned to the upper Aptian-lower Albian Parhabdolithus angustus Zone. Core 392A-4 contains an assemblage of well preserved nannofossils of the Barremian Micrantholithus hoschulzi Zone. An increasing abundance of nannoconids and pentaliths in Cores 392A-2 to 392-4 may indicate a trend toward general shallowing in progressively older sediments.

\section{Depositional Environment}

We recognize three different depositional environments at Site 392 on the basis of microfossil assemblages: (1) Barremian and/or pre-Barremian very shallow marine conditions; (2) Barremian shallow-water conditions, and (3) a late Aptian to late Campanian deep marine realm (see Figure 16).

The microfossil assemblage in the Barremian limestone unit below Core 4 to the bottom of the hole consists of numerous miliolids and a few simple arenaceous or calcareous foraminifers (all recrystallized tests). Such a fauna may occur in very shallow water - possibly marginal marine environments. Sedimentologic evidence discussed in the lithology section above, also suggests that the environment was one of very shallow water. No larger foraminifers (Orbitolina, Pseudocyclammina, Choffatella, or possibly Anchispirocyclina) were found. Fluctuating salinities, shallow water (? tidal flat), or high energy conditions may have been too extreme for them to have lived here.

The Barremian microfossil assemblage in Core 4 contains a great deal of skeletal debris from echinoids, mollusks, and algae or sponges along with a low diversity benthic foraminifer assemblage (mainly lenticulinids and no epistominids). Nannoconids are especially common among the nannofossils. The environment was apparently shallow marine, possibly 50 meters or less water depth.

Upper Aptian, middle-upper Albian, and upper Campanian sediments are clayey nannofossil oozes whose foraminifer content indicates that the water was much deeper when they were deposited. The high plankton/benthos ratio with a negligible number of benthic foraminifers (especially in the upper Campanian sediments) indicates an open marine environment in at least 500 meters of water.

\section{SEDIMENT ACCUMULATION RATES}

Sediment accumulation rates in Hole 392 can be calculated only for the Barremian to Albian interval between Cores 4 to 2 . The absence of biostratigraphic control in the almost 250 meters of Barremian or older 


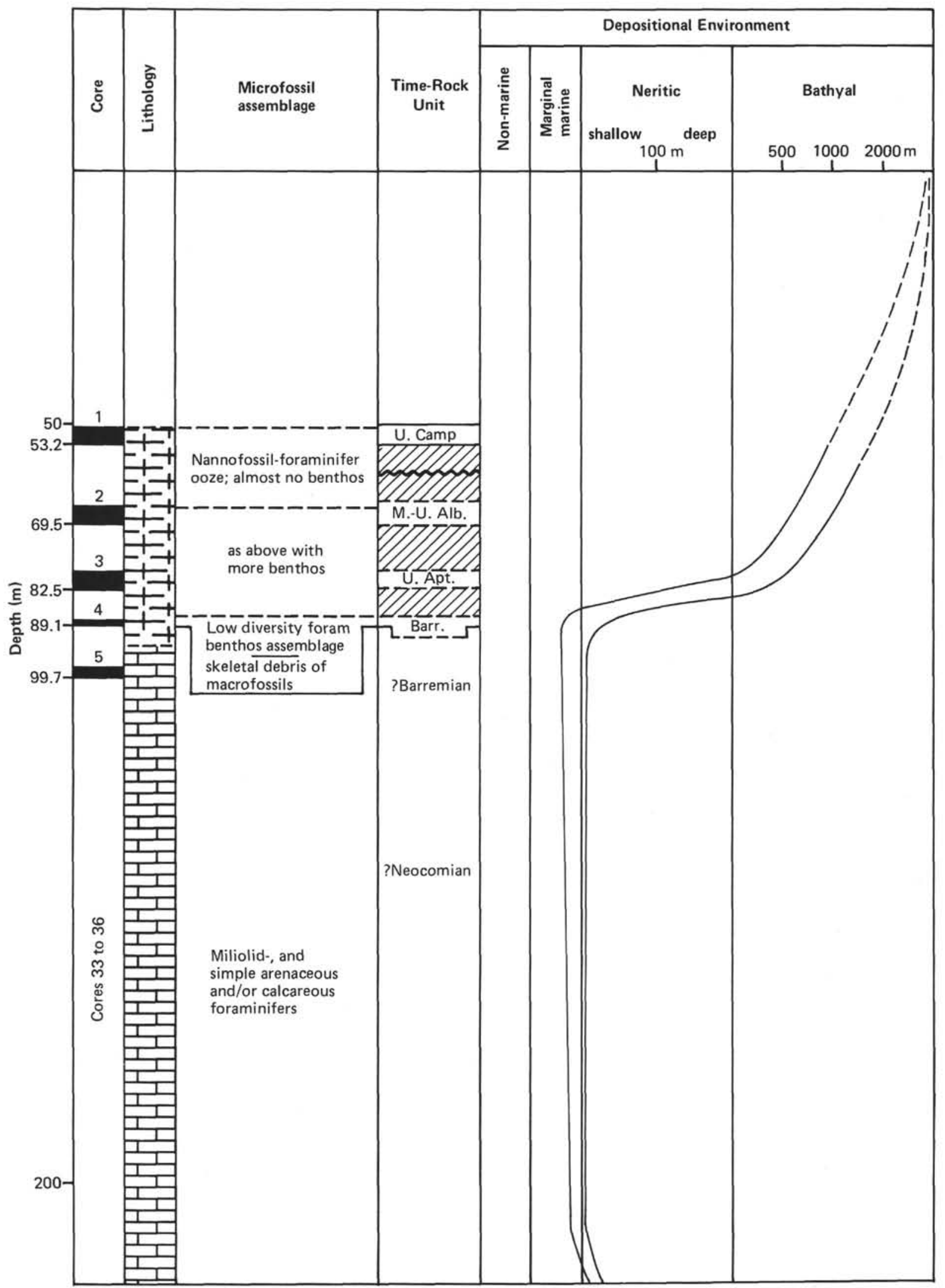

Figure 16. Stratigraphy and depositional environments, Hole $392 \mathrm{~A}$. 
limestone in Cores 5 to 31 precludes calculations. The thickness of the upper Campanian beds is unknown.

If we assume that half of the Barremian, all of the Aptian, all of the lower-middle Albian, and half of the upper Albian occur in or between Cores 392A-4 through 392A-2 and that the Albian-late Campanian hiatus is halfway between Cores 2 and 1, late Barremian to late Albian sedimentation averaged $0.2 \mathrm{~cm} / 1000 \mathrm{yr}$. This is the same rate as in Site 390 (Figure 17).

As Sites 390 and 392 are close together, the similarity in the mid-Cretaceous water depths (Figure 24 in the Site 390 chapter and Figure 16, this chapter) is reasonable and subsidence rates are about the same at the two sites.

\section{CORRELATION OF DRILLING RESULTS WITH SEISMIC REFLECTION PROFILE}

As Glomar Challenger approached Site 392, an airgun seismic profile was run on a course of $300^{\circ}$ (Figure 18) following the line made in the original survey of Site 389. The profile shows the distinct seismic character of the rough hyperbolic reflector which is opaque to acoustic transmission and is interpreted to be a reef-bank or rim complex. Just west of the $3 \mathrm{~km}$-wide reef-complex, sedimentary reflectors as deep as $4.5 \mathrm{sec}$ appear abruptly from within the apparently more massive structure. These sedimentary layers can be traced to Site 390 to allow correlation between the two Blake Nose sites.

Two reflectors were penetrated by Hole 392A: one at $0.07 \mathrm{sec}$ and one at $0.115 \mathrm{sec}$ sub-bottom. The opaque zone originally thought to be reef-complex limestone is below this. The $0.07-\mathrm{sec}$ reflector is correlated with the unconformable interface between the Campanian nannofossil ooze and the firm Aptian-Albian sticky clay and ooze. This correlation gives a reasonable calculated velocity of $1.57 \mathrm{~km} / \mathrm{sec}$ for these near-surface Campanian and younger oozes.

The next deeper reflector above the opaque zone at 0.115 sec sub-bottom is correlated with the rubble-zone contact of the hard limestones just below the Barremian nannofossil ooze. This correlation gives a calculated velocity of 1.78 $\mathrm{km} / \mathrm{sec}$ for the Aptian-Albian to Barremian ooze unit overlying the limestone.
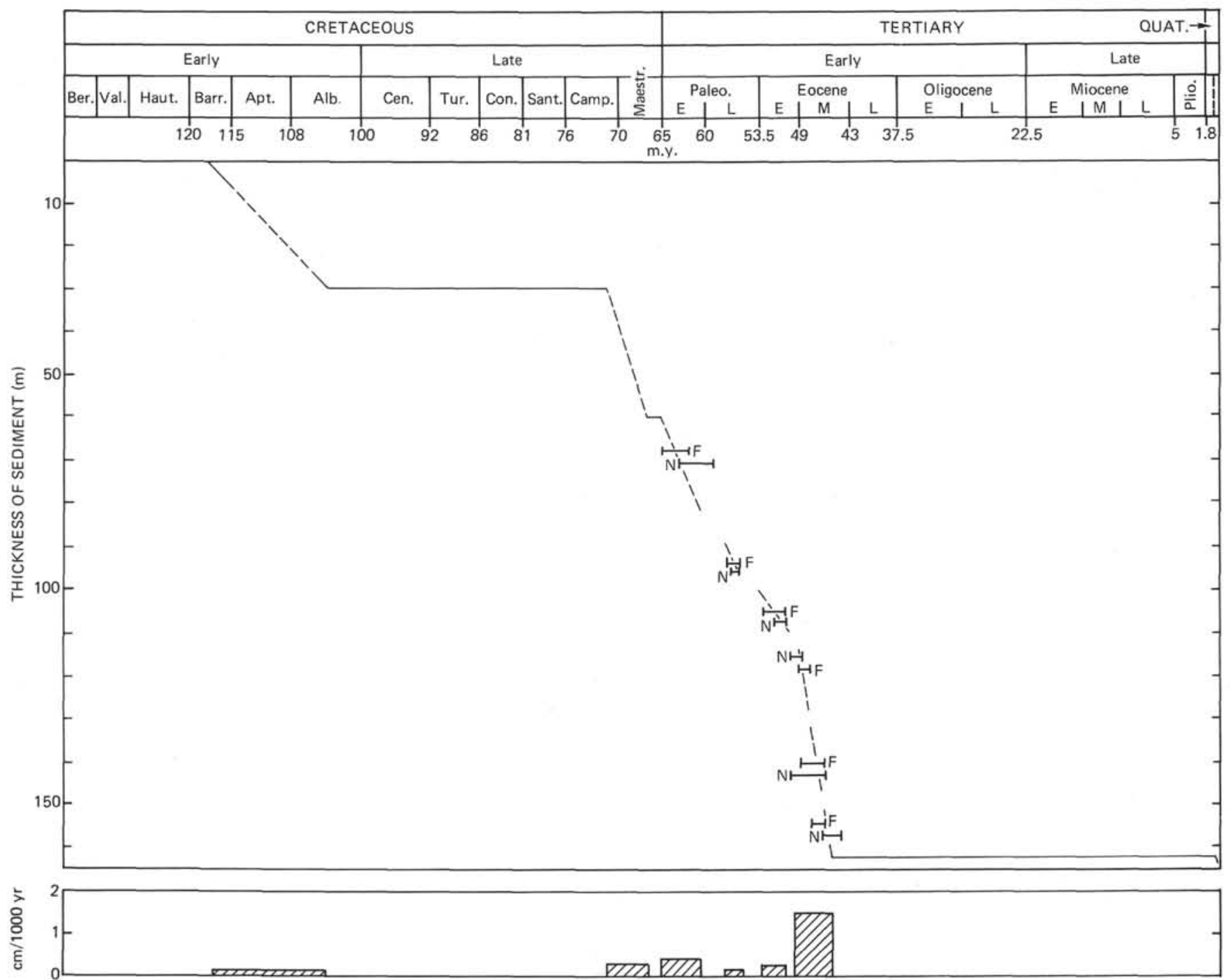

Figure 17. Rate of sediment accumulation, Site 392. 


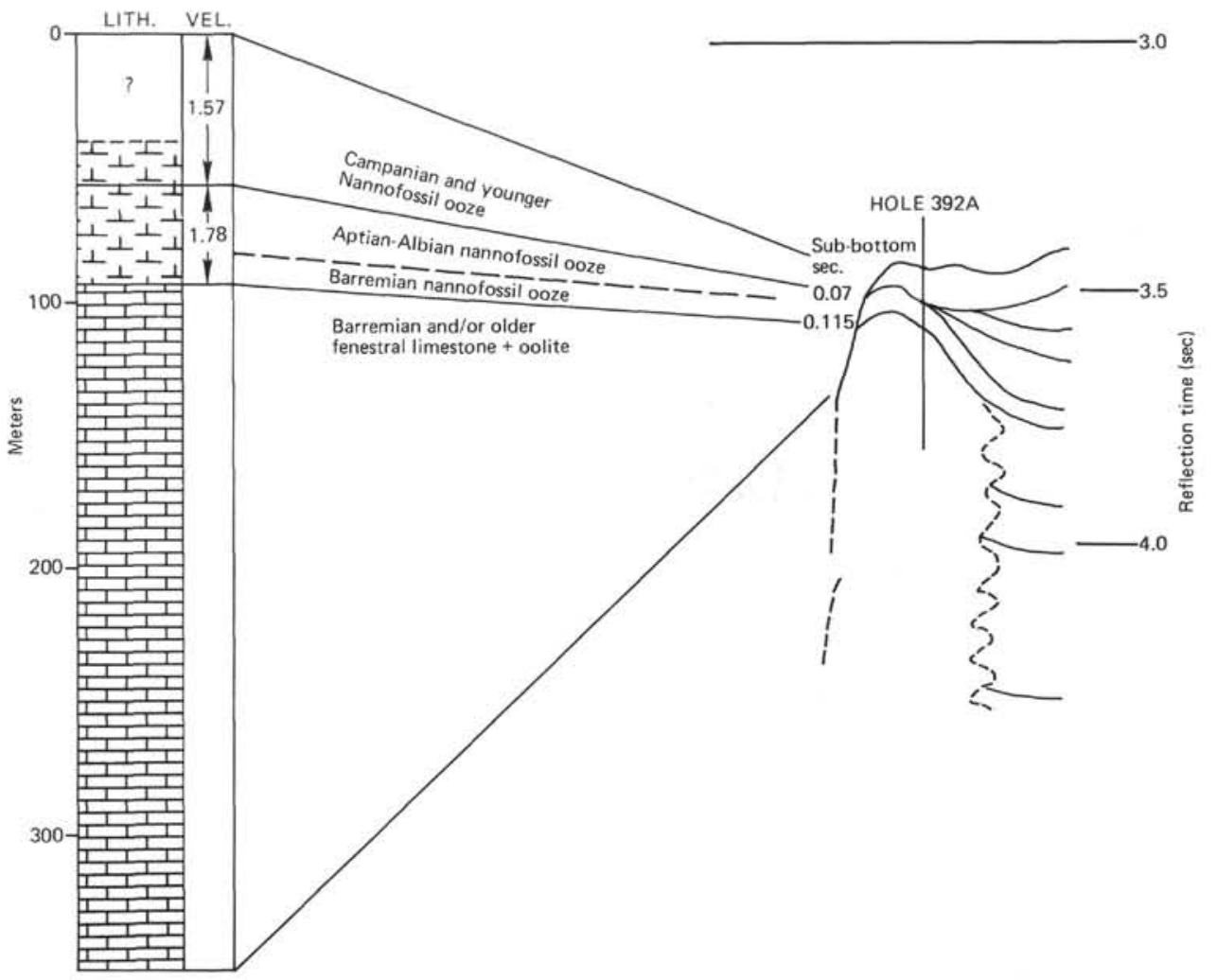

Figure 18. Correlation of lithology with seismic reflection profile, Site 392. Velocities are calculated on basis of correlation of reflectors with drilled boundaries.

No other deeper reflectors were observed on the Site 392 Challenger profile. On the basis of an assumed $5.0 \mathrm{~km} / \mathrm{sec}$ velocity for the hard limestone we infer that Hole 392A only penetrated to about the equivalent of $0.215 \mathrm{sec}$ sub-bottom.

\section{SUMMARY AND CONCLUSIONS}

Our return to the Blake Nose gave us an opportunity to collect more definitive evidence on the history of Cretaceous reef-bank rim-complex. The evidence from the holes drilled at Site 390 allowed us to develop a reasonable model of reef-complex development, but it is not exclusive and relies entirely on seismic extrapolation from Site 390 to the inferred reef complex some $25 \mathrm{~km}$ away. Also, in that model several seismically identified layers of possible Cenomanian to Santonian(?) age, thought to be present on the Blake Nose, could not be correlated definitively because of the Campanian/Albian hiatus at Site 390.

We planned to sample some of these Cenomanian-Santonian beds at Site 392 - if they indeed reached that site - to penetrate the reef complex to several hundred meters and to study the carbonate microfacies present.

Drilling at Site 392 recovered a section of ooze overlying hard recrystallized limestone of near-reef or at least near-shore peri-reefal facies (Figure 19). No Santonian to Cenomanian sediments were found. The hiatus in the Cretaceous oozes is from Campanian to Aptian and the ooze overlying the hard limestone is of Barremian age, both as at Site 390.

Drilling at Site 392 penetrated 260 meters of hard limestone, the upper $10-15 \mathrm{~cm}$ of which has been brecciated, weathered, and cemented by iron oxides. The upper zone also contains small concretionary, pisolites of limonite. Discovery of coccoliths incorporated in these pisolites indicates that they formed in an open marine environment.

The limestone itself comprises three lithologic types, all of which were deposited in shallow-water. The top 113 meters was deposited in a tidal flat environment, possibly behind an island barrier which provided a wave-protected lagoon. All the limestone has been recrystallized and some of the secondary features are diagnostic of alteration above the water table. The lower part of the section is cavernous which also suggests solution by meteoric waters.

The simplest model for the deposition of the limestone sequence is a single cycle starting with a shelf or bank, gradual shoaling to tidal flats, and final exposure to subaerial weathering. Several features associated with the solution and recementation of certain beds, however, suggest that this simple model may have been complicated by more than one emergence above sea level and consequent subaerial diagenesis. In view of the worldwide fluctuations of Cretaceous sea level, several emergences very likely took place.

\section{Cretaceous Reef Building on the Blake Nose}

The results of drilling at Hole 392A and the correlation of seismic profiles gives a final interpreted cross-section of the Blake Nose (Figure 20). Note that we infer that Santonian-Cenomanian sedimentary layers probably underlie the northwest portion of the Blake Nose, and that 


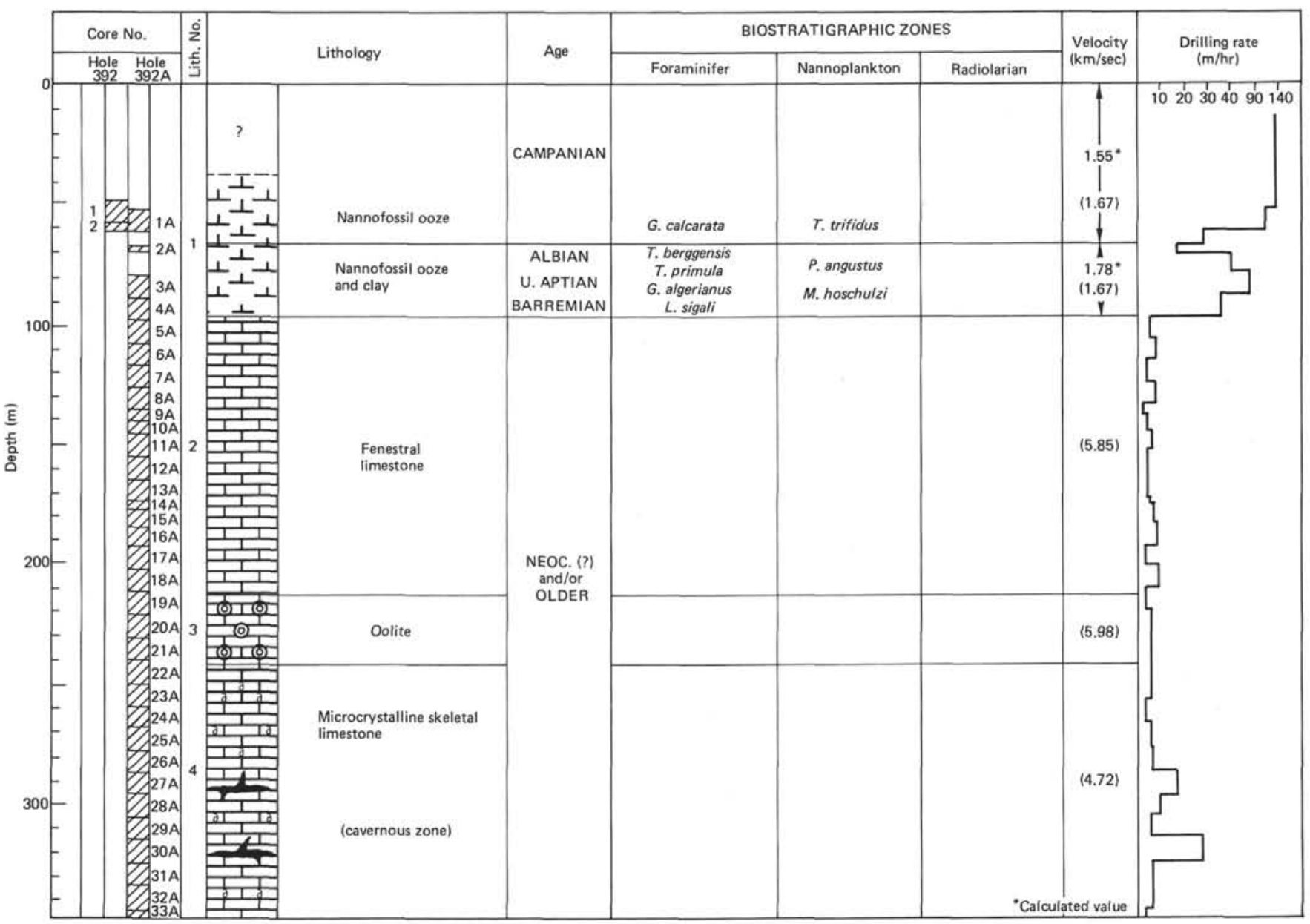

Figure 19. Graphic hole summary, Site 392.

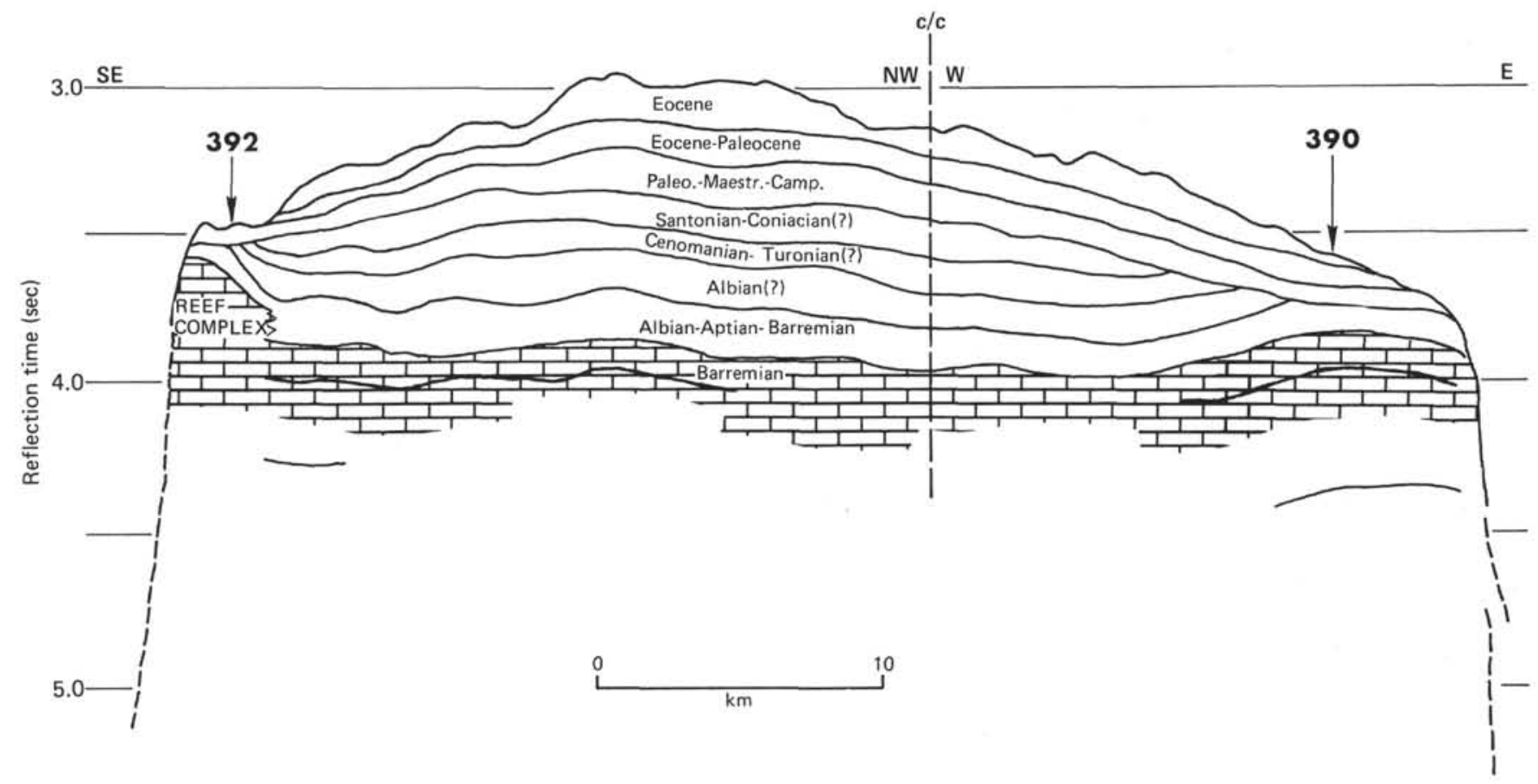

Figure 20. Interpreted geologic cross-section of the Blake Nose on basis of Sites 390 and 392 drilling. 
the same Campanian/Albian hiatus of Site 390 is also present at Site 392.

Drilling at Site 392 did give definitive data on the termination of the reef bank-rim complex buildup. The upper contact of the tidal-flat fenestral limestone is an erosion surface directly overlain by deeper marine Barremian sediments. In fact, the overlying Barremian, Aptian-Albian, and Campanian sediments all record an increasingly pelagic and deep-water environment. Clearly shallow-water bank-margin carbonate deposition on the Blake Nose did not continue through Barremian time.

This termination shallow-water carbonate accumulation might explain the difference in present depth between the reef-bank complex on the Blake Nose, at about 2650 meters, and the margin bank complex on the lip of the Blake Escarpment from just south of the Nose to the area of Great Abaco Canyon, at about 1500 meters. If these reef complexes were of the same age, the Blake Nose block would have had to have faulted downward relative to the rest of the Blake Plateau (Ewing et al., 1966). The termination of reef-bank rim complex buildup on the Blake Nose by Barremian time contrasts with the possible Cenomanian-Campanian age for the 1500 meter rim complex along the rest of Blake Escarpment (Sheridan et al., 1971). Dredging just below this 1500-meter lip recovered Upper Cretaceous ostracode-rich miliolid limestone, probably a lagoonal facies of the rim complex, and Albian miliolid limestone at 2300 to 2400 meters (Heezen and Sheridan, 1966). From this we infer that the shallow-water platform complex persisted until Campanian (?) time along the escarpment but had ceased to form on the Blake Nose by the end of Neocomian or at Barremian time. This interpretation does not require faulting or any other structural adjustment to lower the Blake Nose relative to the Blake Plateau.

\section{REFERENCES}

Bartenstein, H. Bettenstaedt, F. and Bolli, M. H., 1957. Die Foraminifern der Unterkreide von Trinidad, B.W.I. teil I: Eclog. Geol. Helv., 50, (1), pp. 5-65.
Bolli, H. M., 1966. Zonation of Cretaceous to Pliocene Marine Sediments Based on Planktonic Foraminifera: Bol. Inform. Assoc., Venezuelana Geol. Miner. Petrol., v. 9, no. 1, p. 3-32.

Boyce, R.E., 1973. Physical properties-methods. In Edgar, N.T., Saunders, J.B., et al., Initial Reports of the Deep Sea Drilling Project, Volume 15: Washington (U.S. Government Printing Office), p. 1115-1124.

Enos, Paul, 1974. Reefs, platforms, and basins of the Middle Cretaceous of northeast Mexico, Am. Assoc. Petrol. Geolog. Bull., v. 58 , p. $800-809$.

Ewing, J. I., Ewing, M. and Leyden, R., 1966. Seismic Profiler Survey of the Blake Plateau: Amer. Assoc. Petrol. Geol. Bull., v. 50 , p. $1948-1971$.

Heezen, B. C. and Sheridan, R. E., 1966. Lower Cretaceous Rocks (Neocomian-Albian) Dredged from Blake Escarpment: Science, v. 154, pp. 1644-1647.

Lancelot, Y., Hathaway, J.C., and Hollister, C.D., 1972. Lithology of sediments form the Western North Atlantic, Leg XI. In Hollister, D.C., Ewing, J.I., et al., Initial Reports of the Deep Sea Drilling Project, Volume 11: Washington (U.S. Government Printing Office), p. 901-950.

Meyerhoff, A.A. and Hatten, C.W., 1974. Bahamas salient of North America. In Geology of Continental Margins, Burk, C.A. and Drake, C.L., (Eds.), New York, (Springer Verlag), p. $429-446$.

Schlee, J., Behrendt, J.C., Grow, J.A., Robb, J.M., Mattick, R.E., Taylor, P.T., and Lawson, B.J., 1976. Regional framework off northeastern United States, Am. Assoc. Petrol. Geol. Bull., v. 60, p. 926-951.

Sheridan, R. E., Berman, R. M., and Corman, D. B., 1971. Faulted Limestone Block Dredged from Blake Escarpment: Geol. Soc. Amer. Bull., v. 82, p. 199-206.

Sigal, J., 1966. Contribution a une Monographie der Rosalines I le Genre Ticinella reichel, souche des Rotalipores: Eclog. Geol. Helv., v. 59, no. 1, p. 185-218.

Simon, W. and Bartenstein, H. et al., 1962. Leitfossilien der Mikropalaontologie Gebr. Borntraeger, Berlin.

van Hinte, J. E., 1972. The Cretaceous Time Scale and Planktonic Foraminiferal Zones: Proc. Kon. Nederl. Akad. Wetensch., ser. B, v. 75 , no. 1 , p. $1-8$. 

Hole 392 Core 1 Cored Interval: 47.5-57.0 m

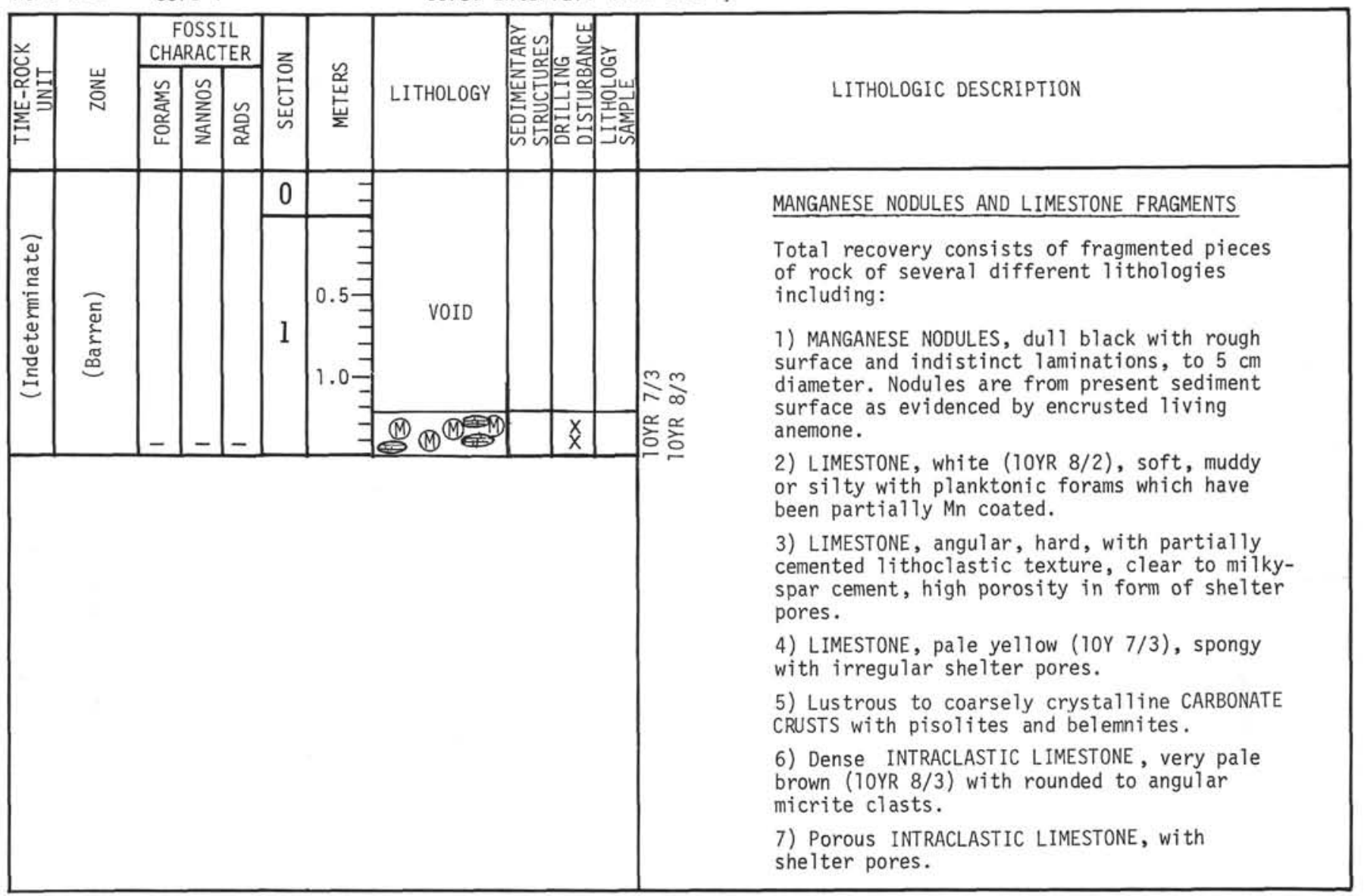

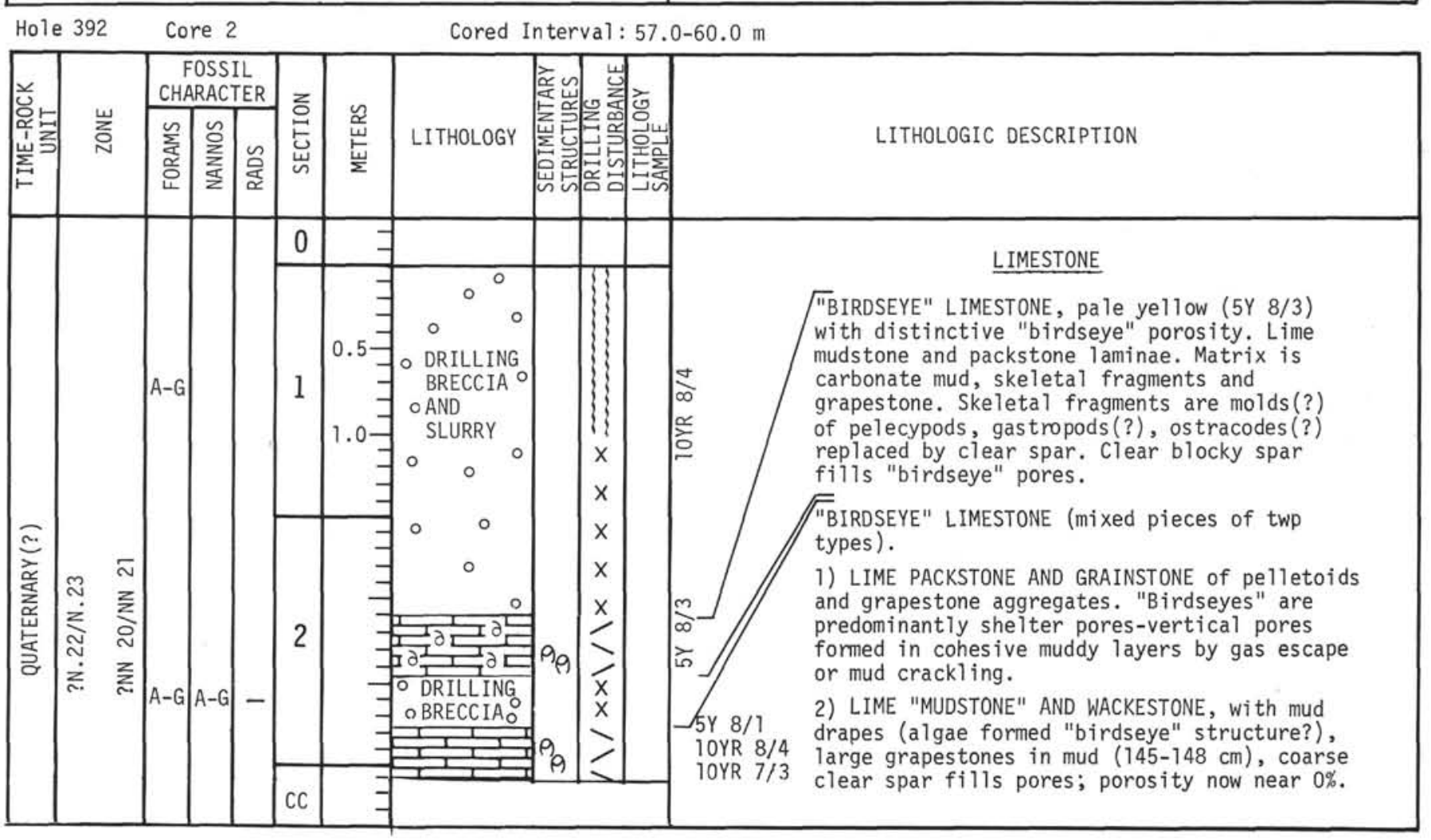




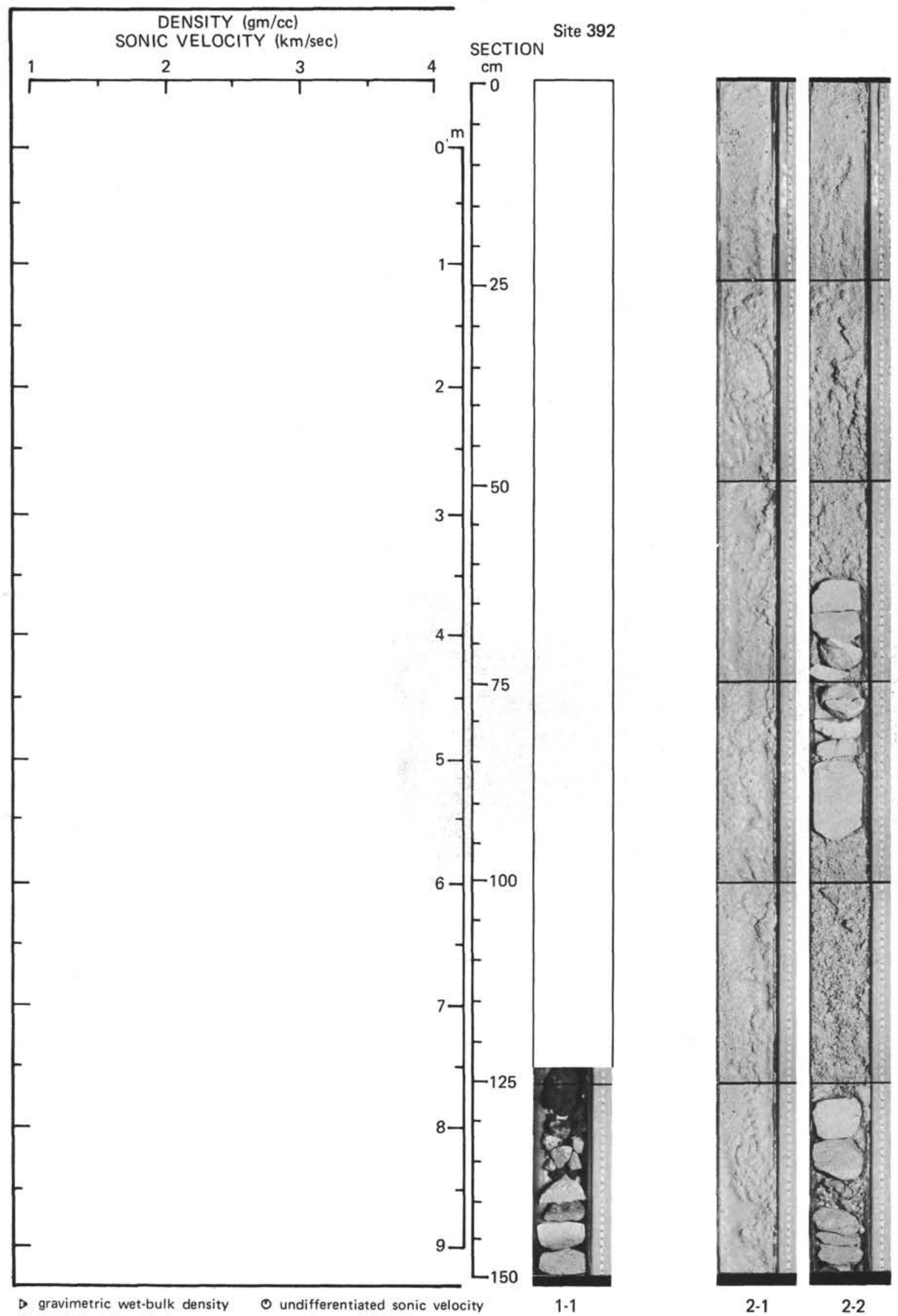

$\rightarrow$ parallel sonic velocity 〜 continuous GRAPE

+ perpendicular sonic velocity 
Hole 392A Core 1

Cored Interval: 50.5-60.0 m

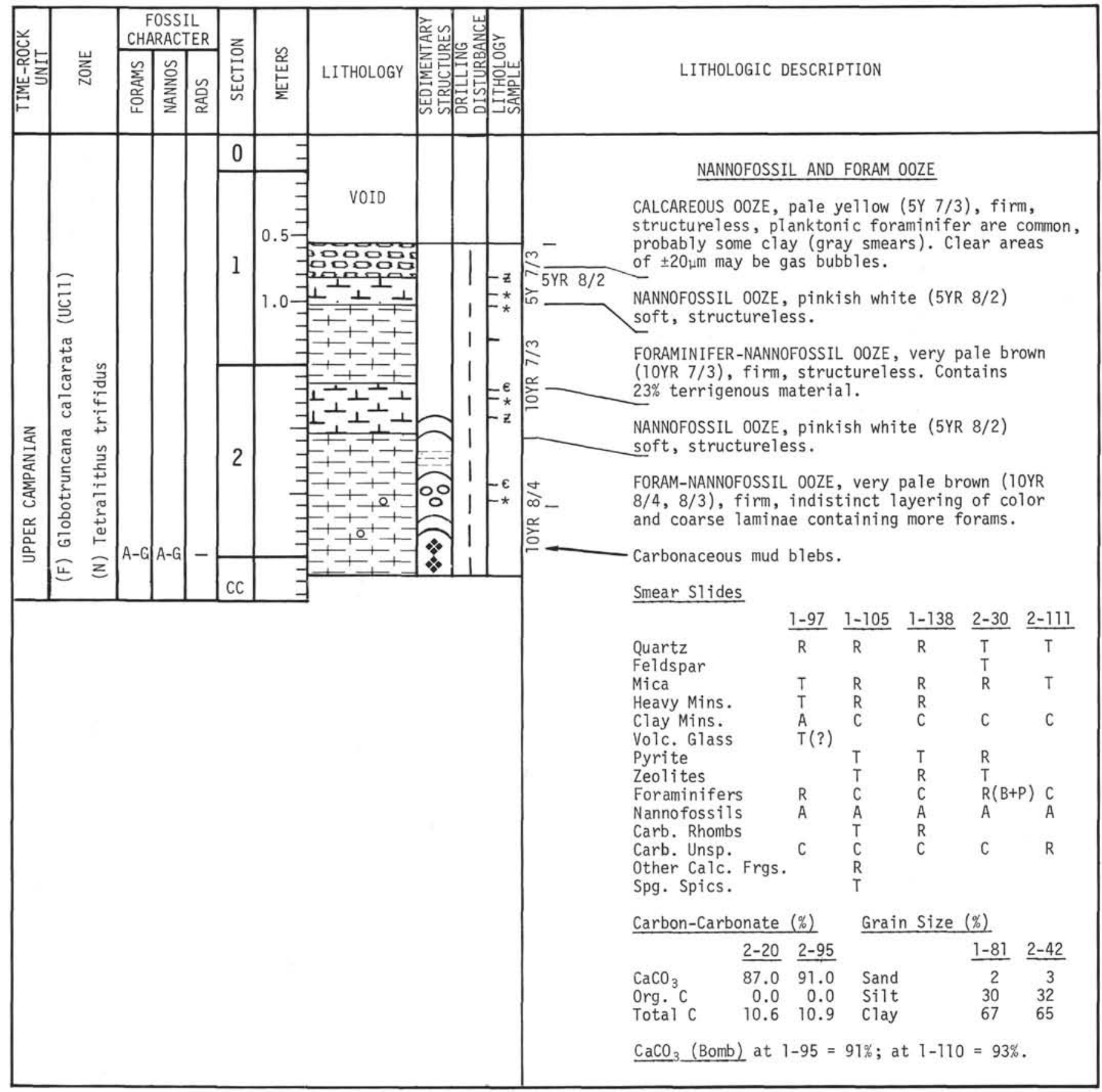




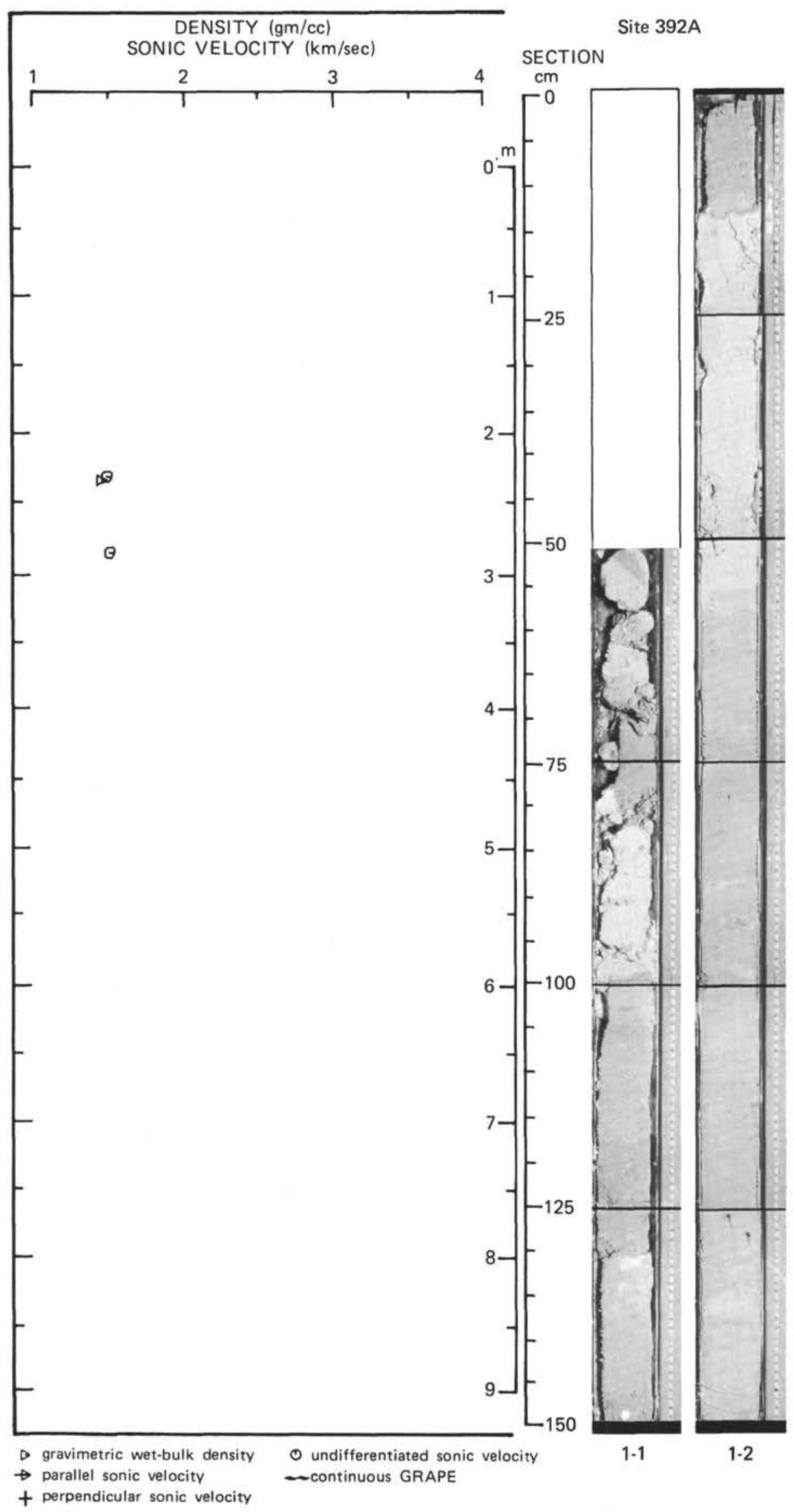




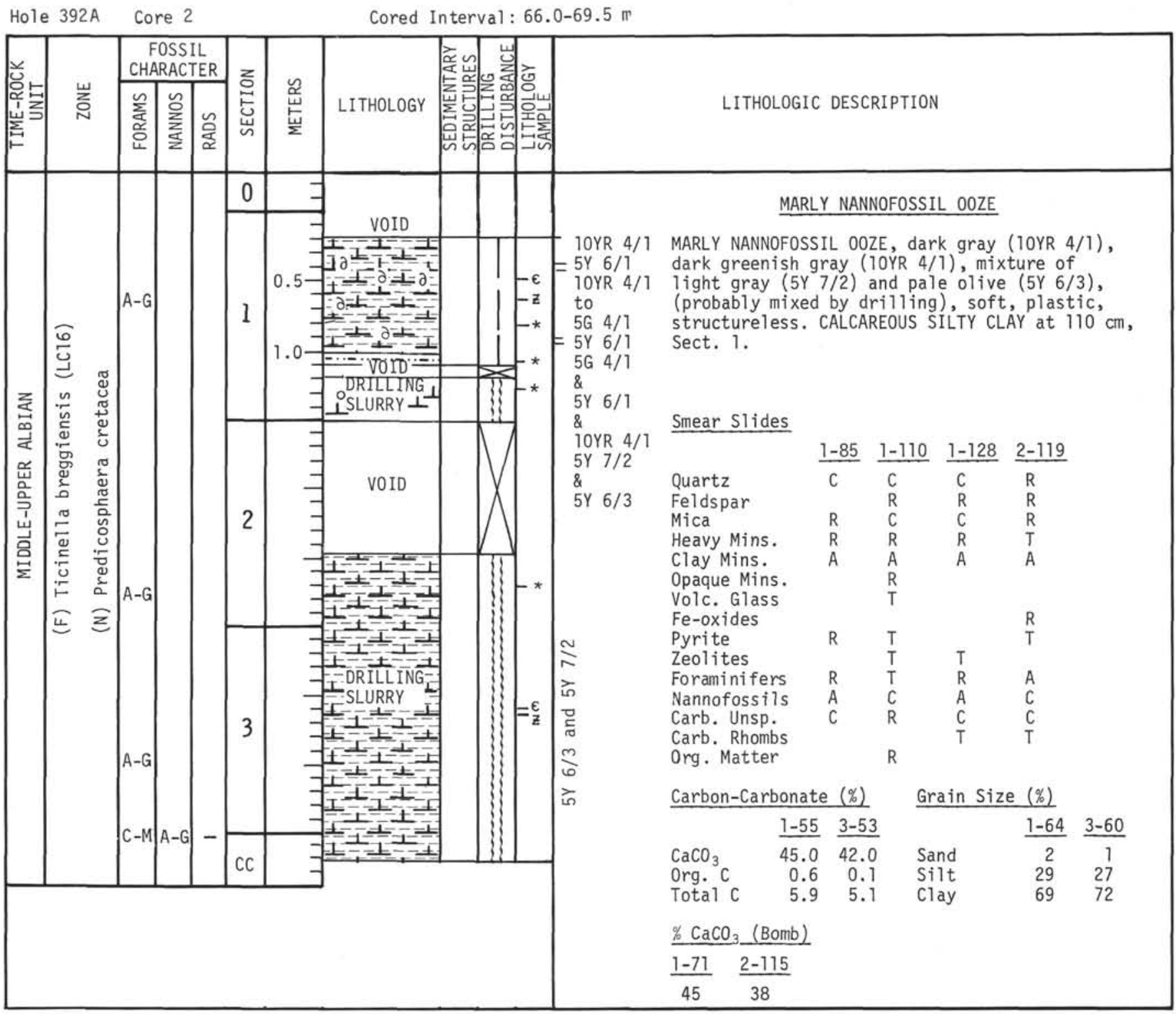




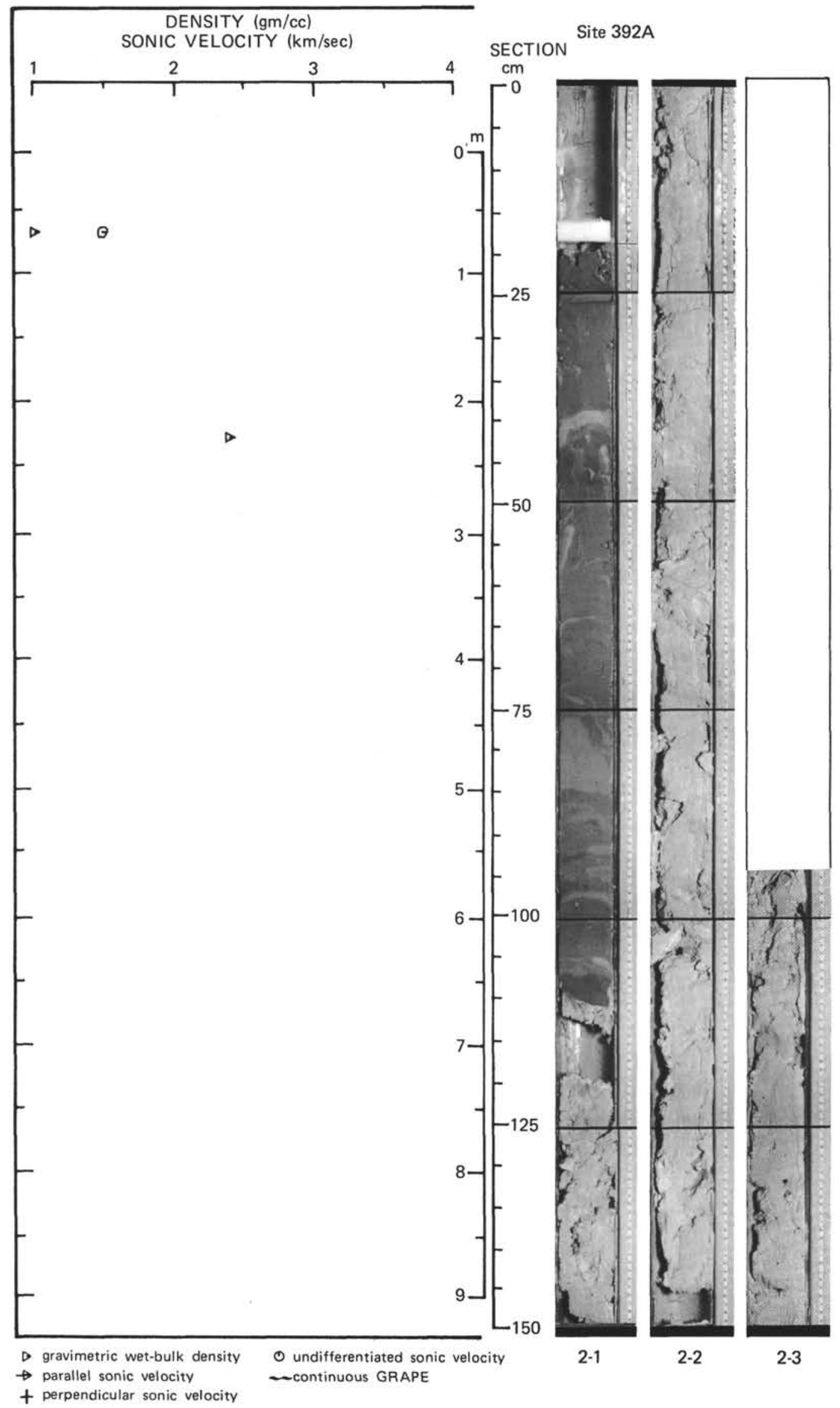


Hole 392A Core 3 Cored Interval: 79.0-88.5 m

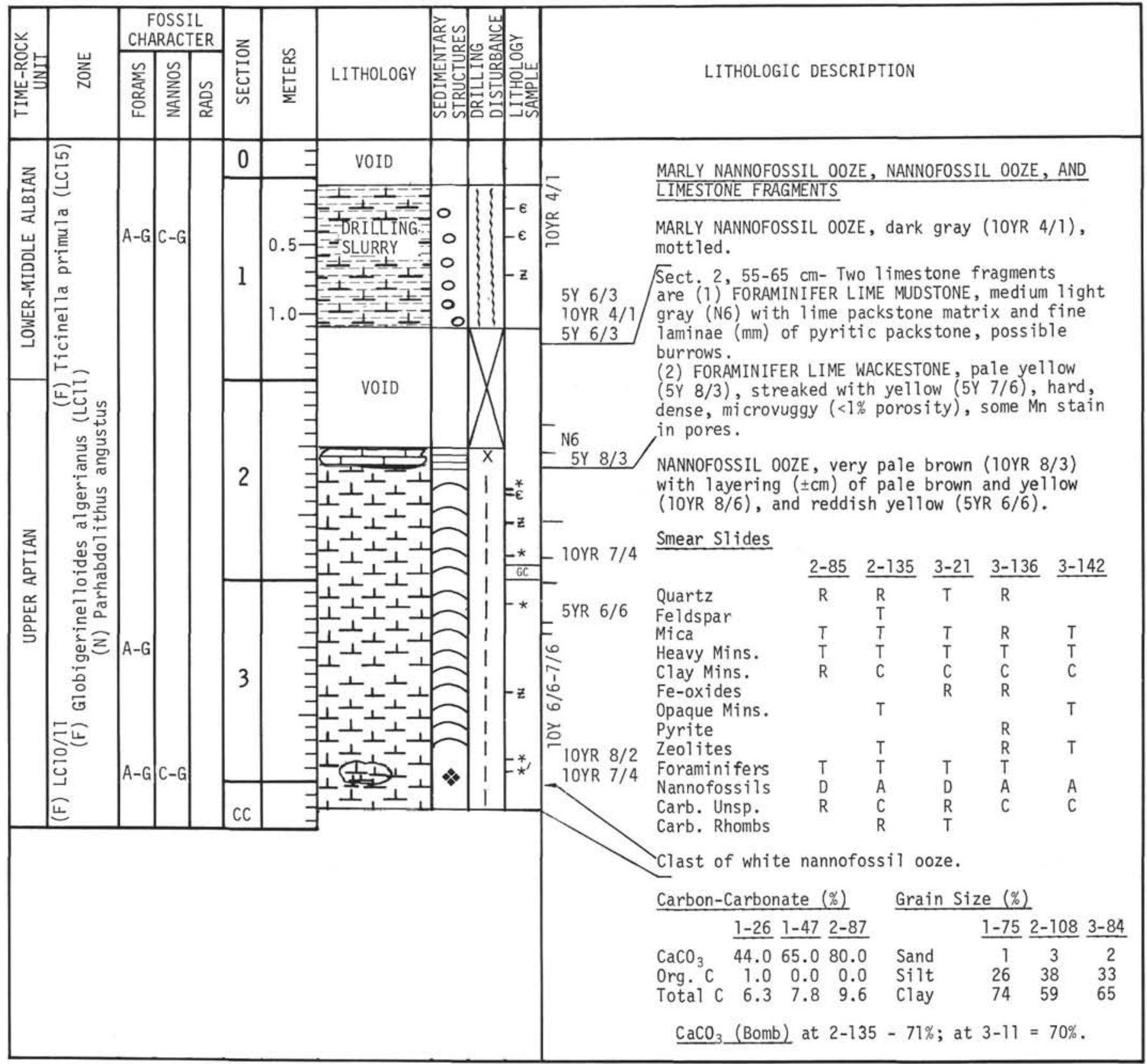




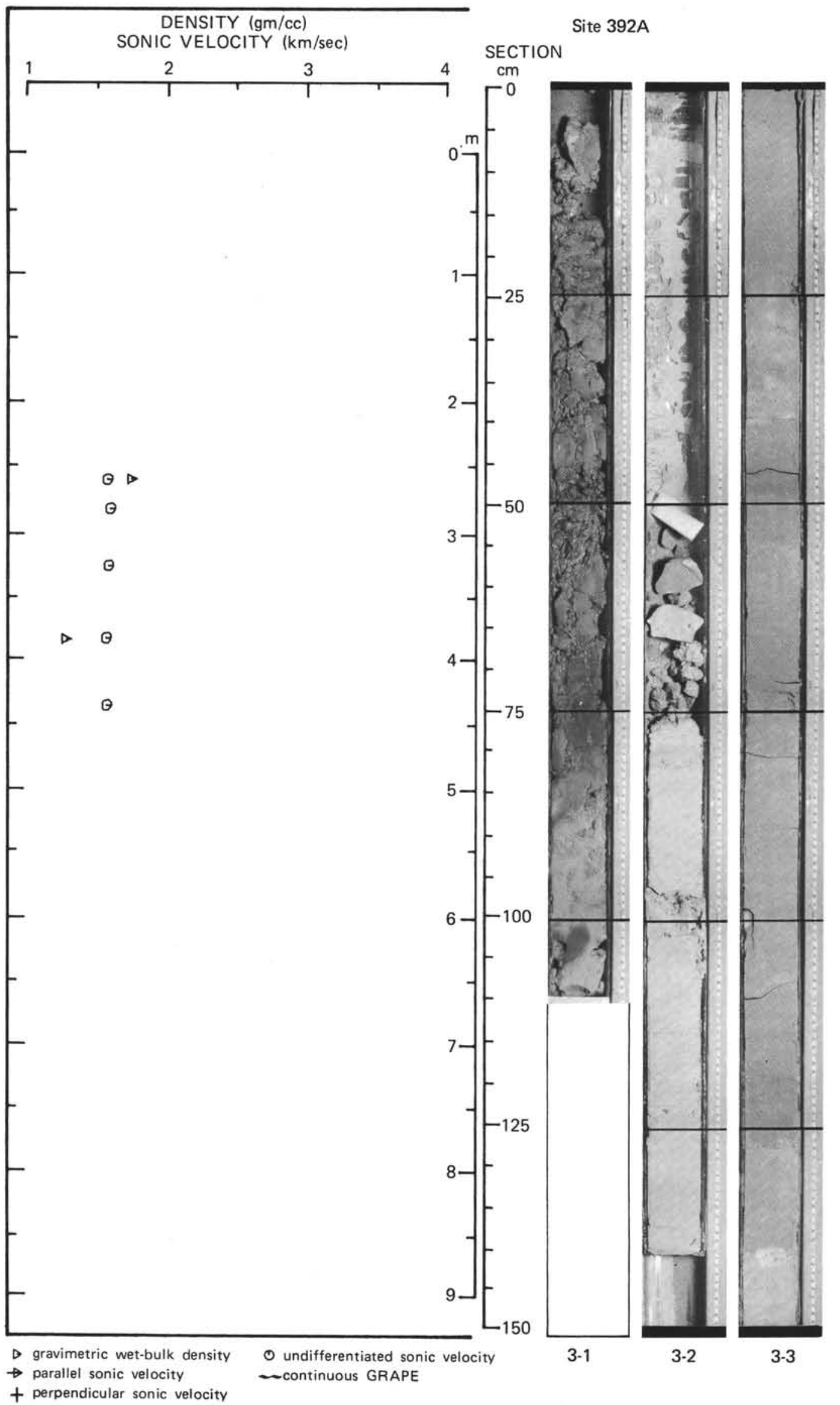




\begin{tabular}{|c|c|c|c|c|c|c|c|c|c|c|c|c|}
\hline \multirow{2}{*}{ 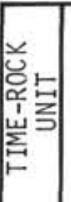 } & \multirow[b]{2}{*}{ 岁 } & \multicolumn{3}{|c|}{$\begin{array}{c}\text { FOSSIL } \\
\text { CHARACTER } \\
\end{array}$} & \multirow{2}{*}{$\begin{array}{l}\text { zo } \\
\text { 总 } \\
\text { w }\end{array}$} & \multirow[b]{2}{*}{ 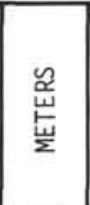 } & \multirow[b]{2}{*}{ LITHOLOGY } & \multirow{2}{*}{\multicolumn{2}{|c|}{ 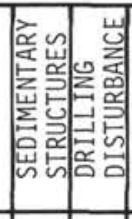 }} & \multirow{2}{*}{ 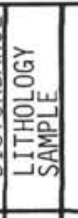 } & & \multirow[b]{2}{*}{ LITHOLOGIC DESCRIPTION } \\
\hline & & 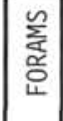 & 量 & 望 & & & & & & & & \\
\hline 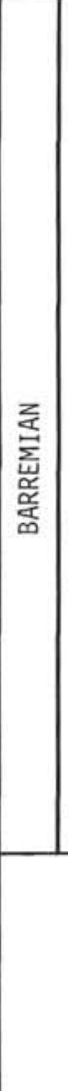 & 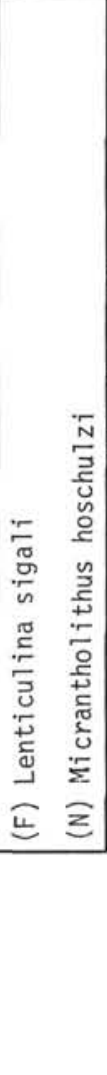 & $\begin{array}{l}C-G \\
C-M\end{array}$ & $C-G$ & & 0 & 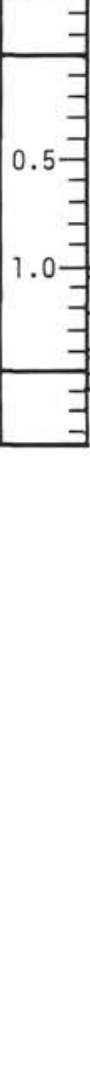 & VOID & 8 & $\frac{3}{2}$ & & $\begin{array}{c}\text { 10YR } 8 / 3 \\
10 Y R \quad 6 / 6 \\
1 \text { 1OYR } 8 / 3 \\
=10 Y R \quad 6 / 4 \\
5 \text { YR } 7 / 4 \\
10 Y R \quad 8 / 3\end{array}$ & 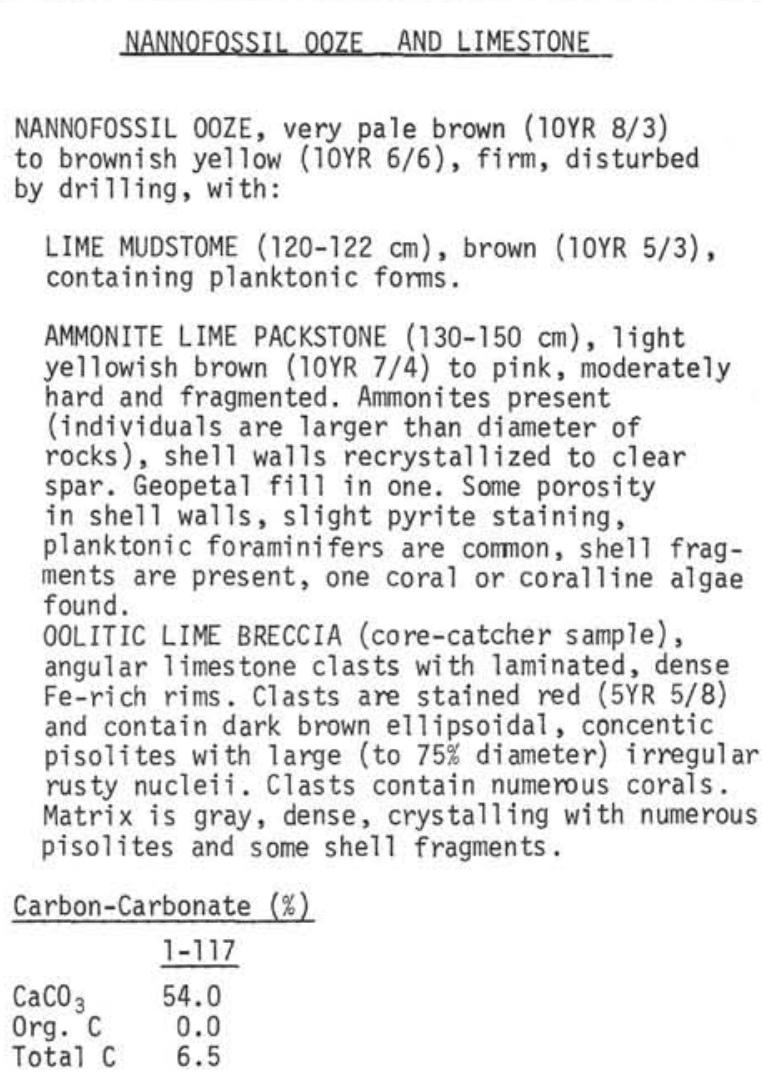 \\
\hline
\end{tabular}




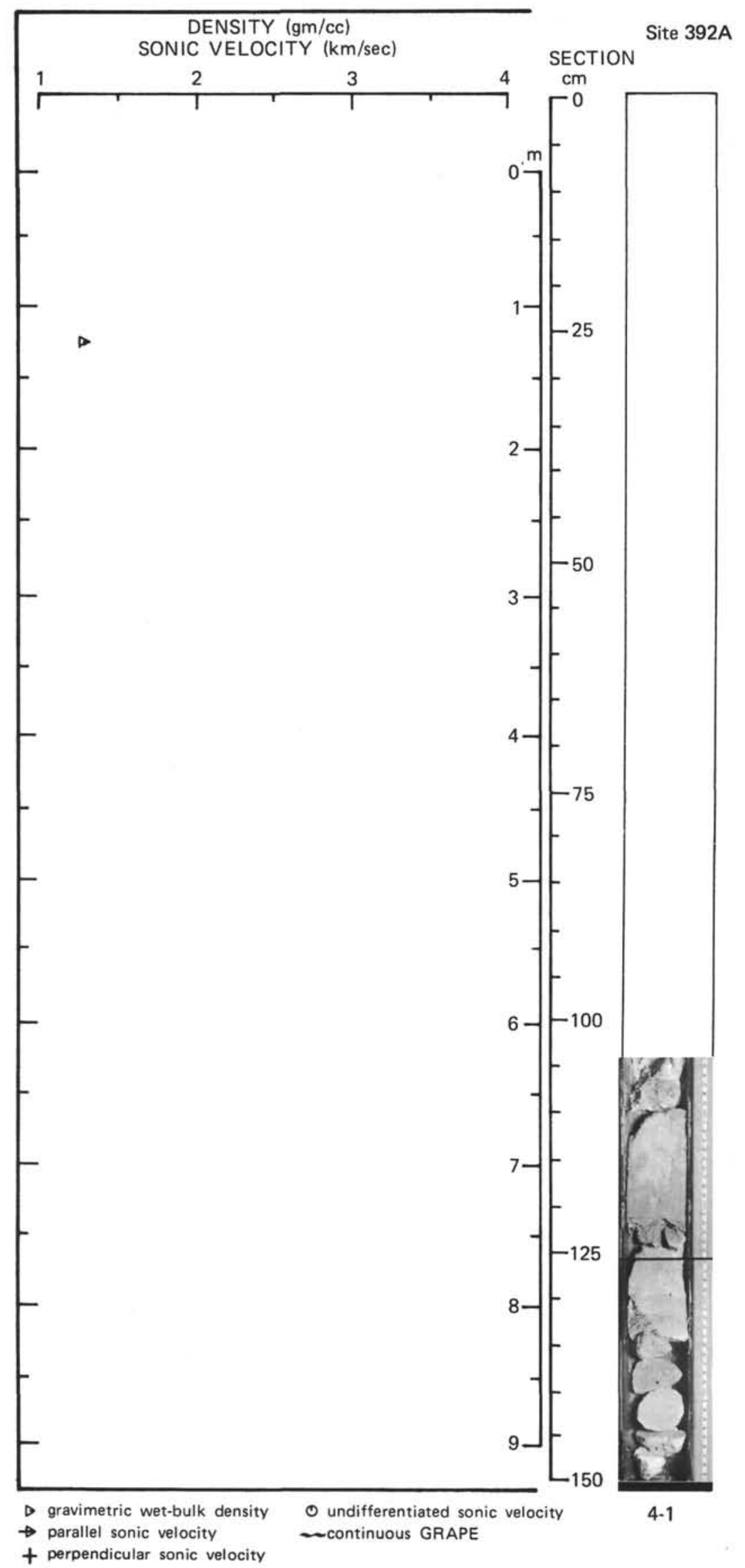




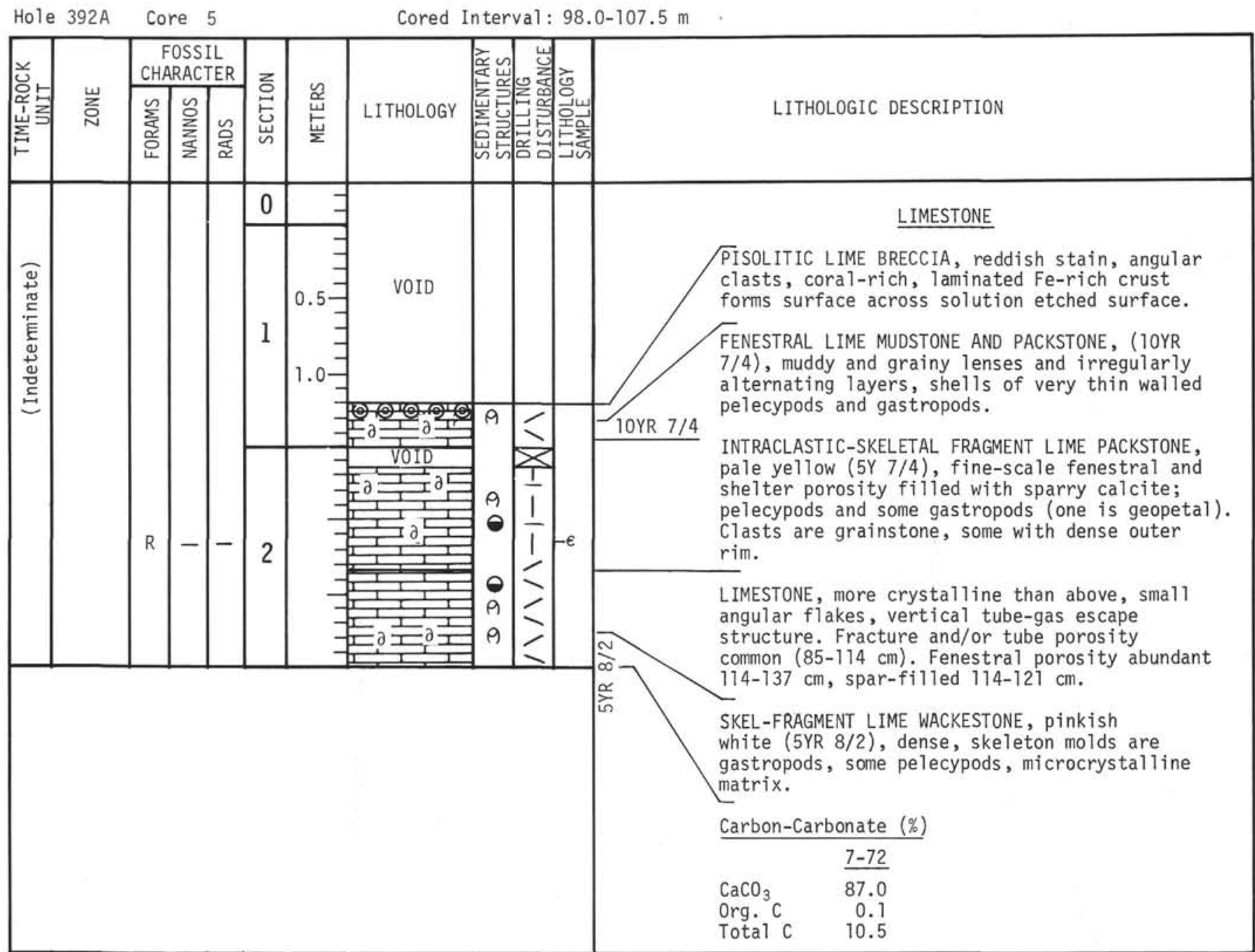

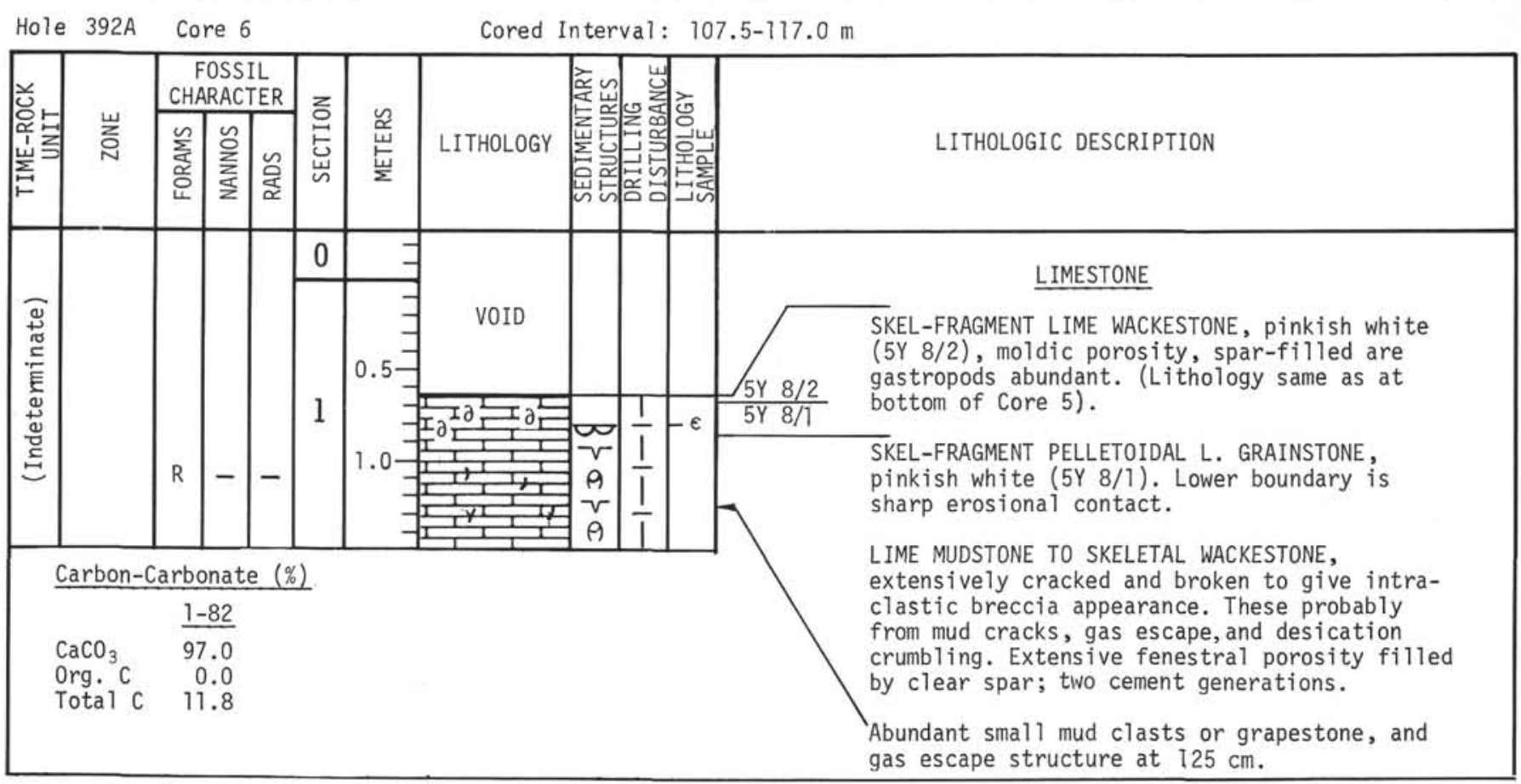




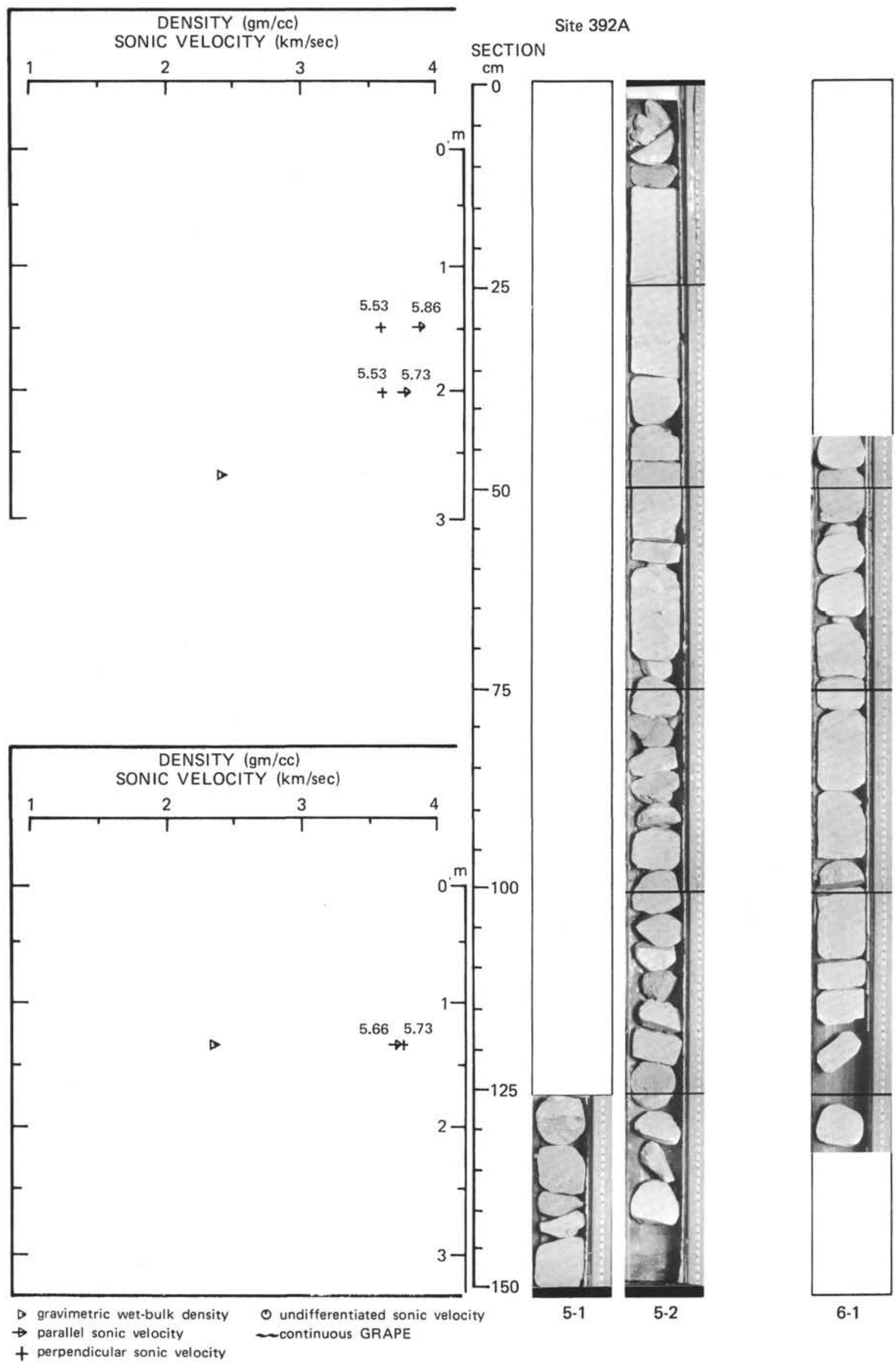




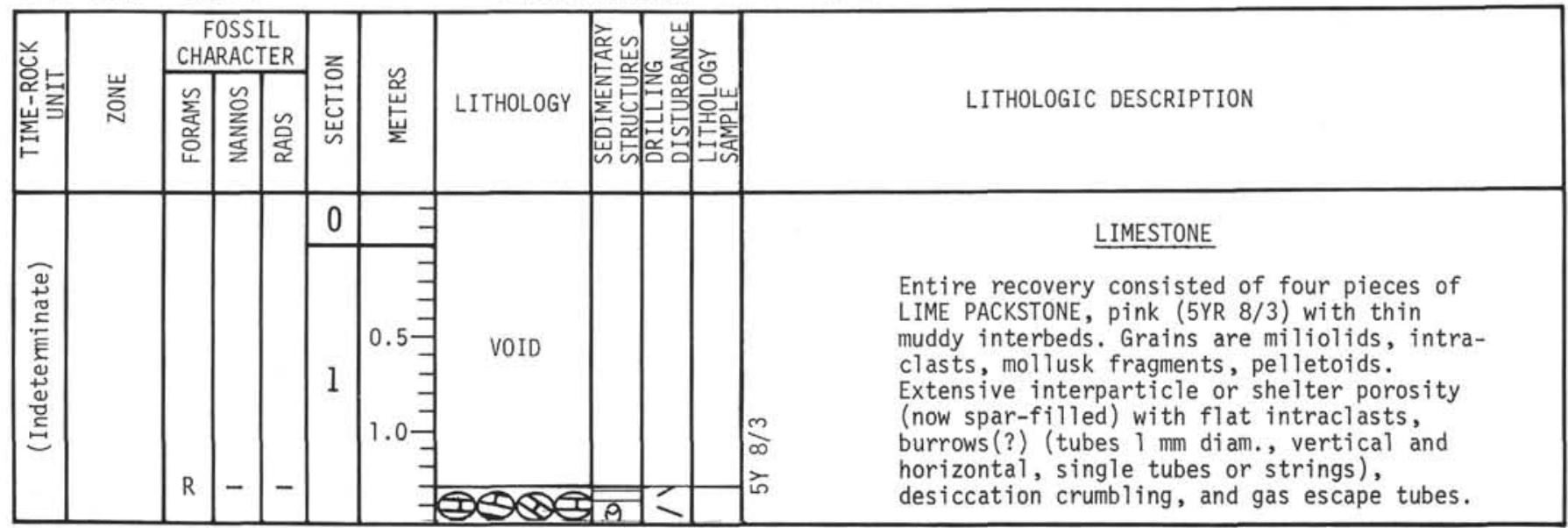

Hole $392 \mathrm{~A}$ Core 8

Cored Interval: 126.5-136.0 m

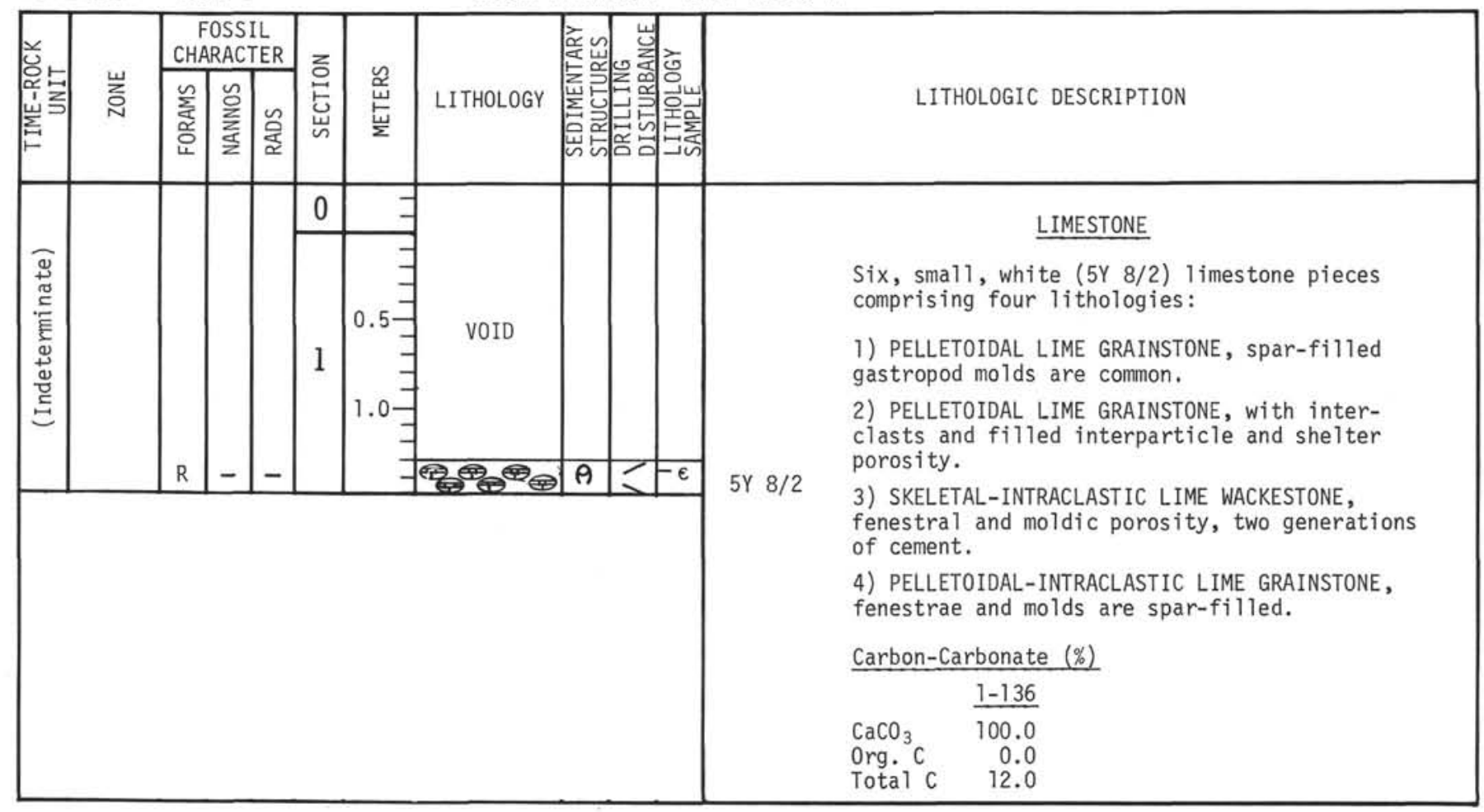




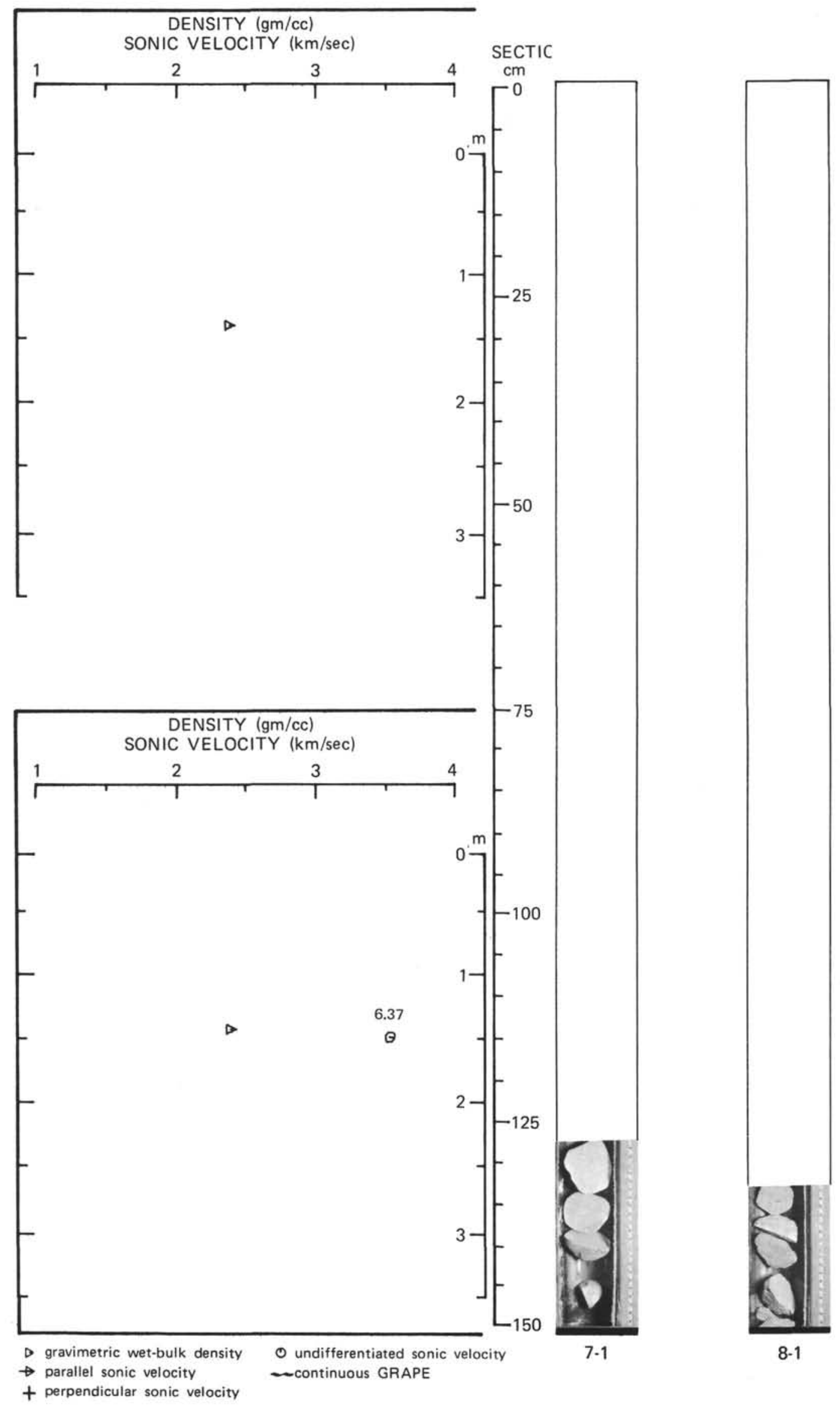




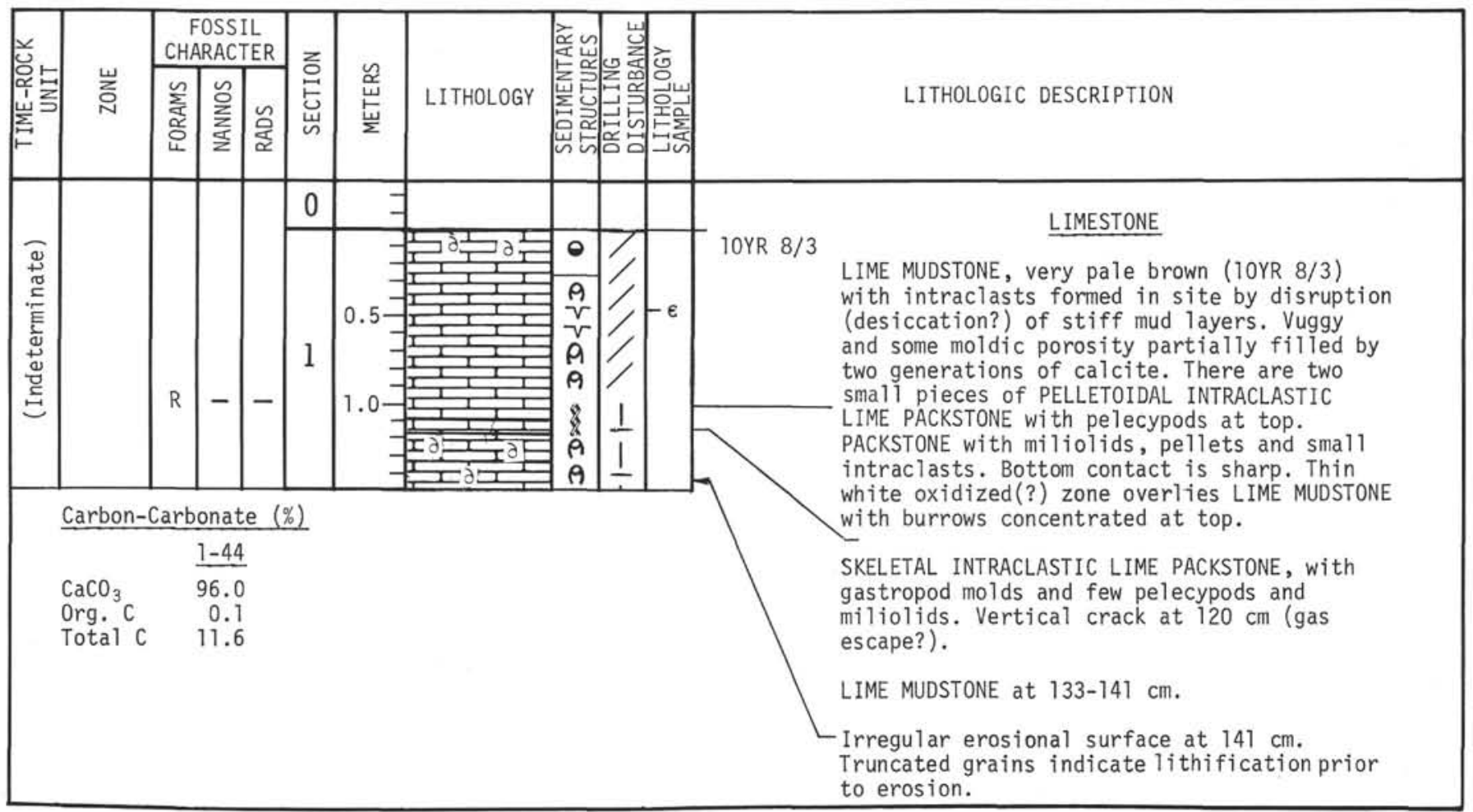

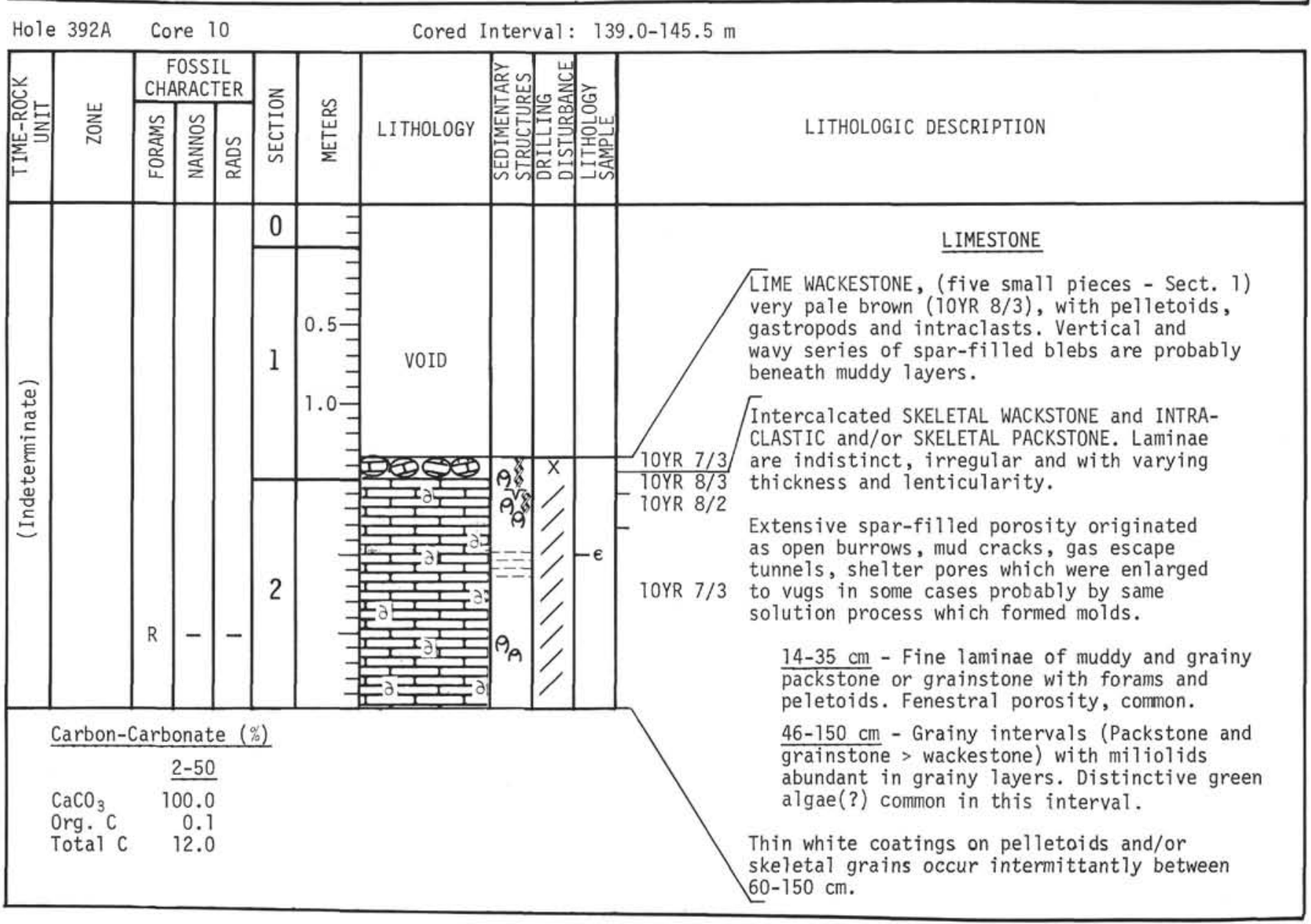



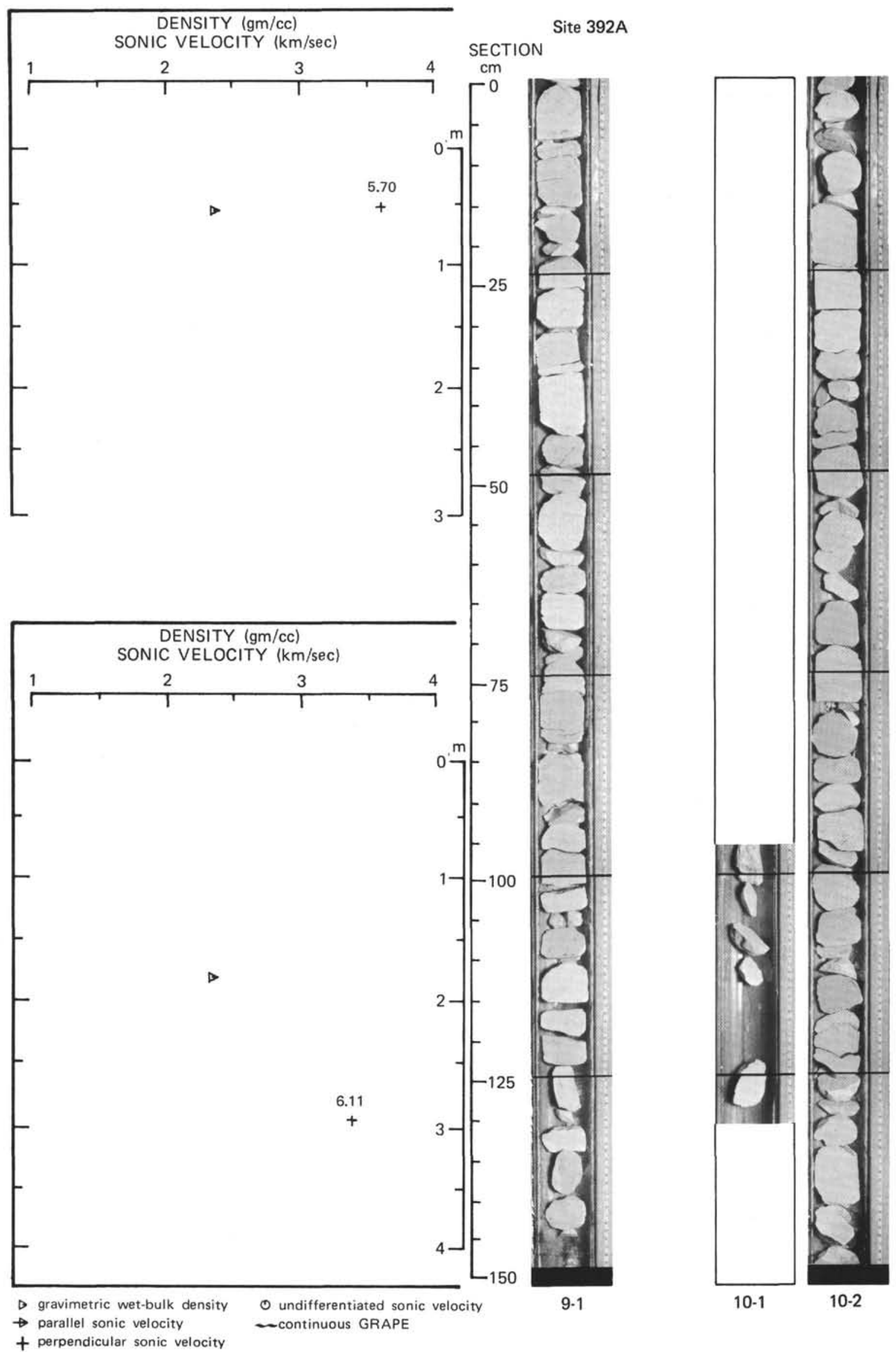

+ perpendicular sonic velocity 
Hole 392 A Core 11

Cored Interval: 145.5-155.0 m

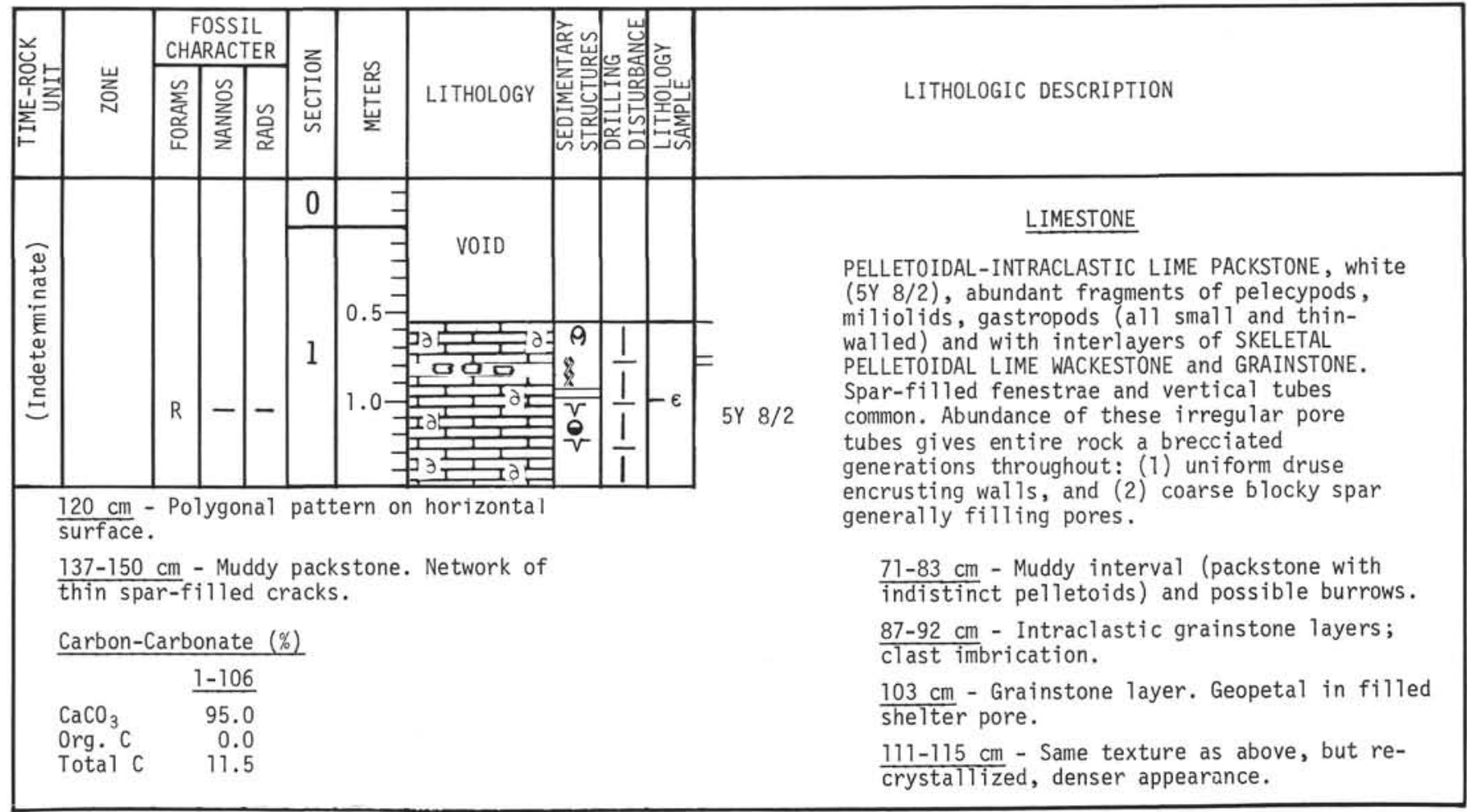

Hole 392A Core $12 \quad$ Cored Interval: $155.0-164.5 \mathrm{~m}$

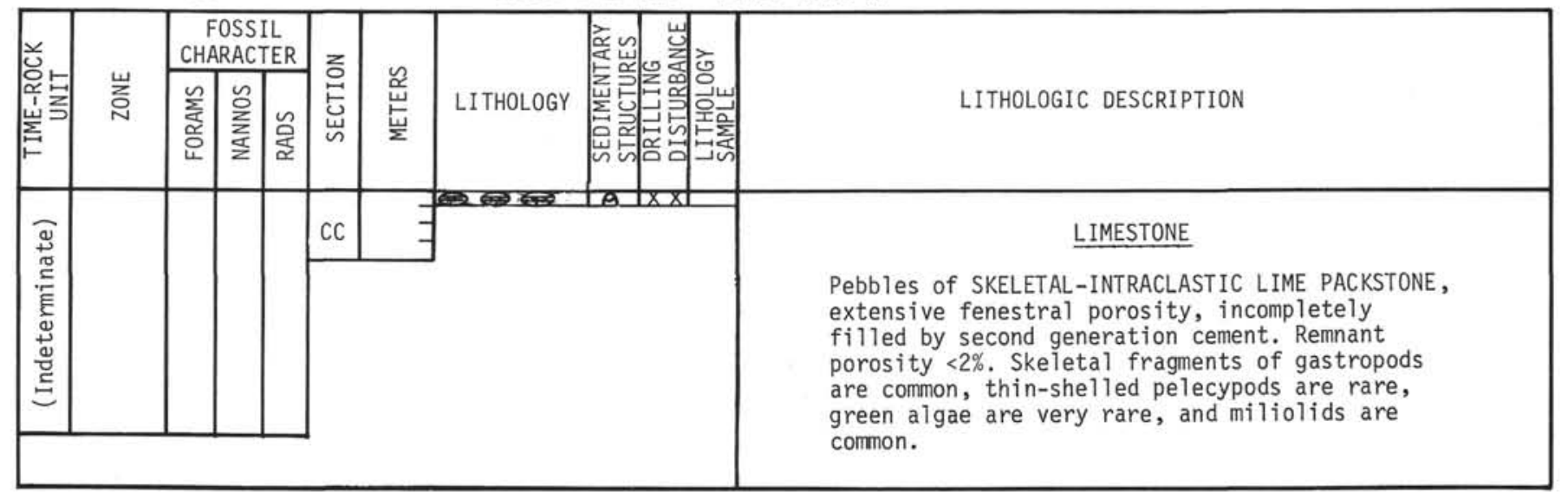

Hole $392 \mathrm{~A}$ Core 13

Cored Interval: 164.5-174.0 m

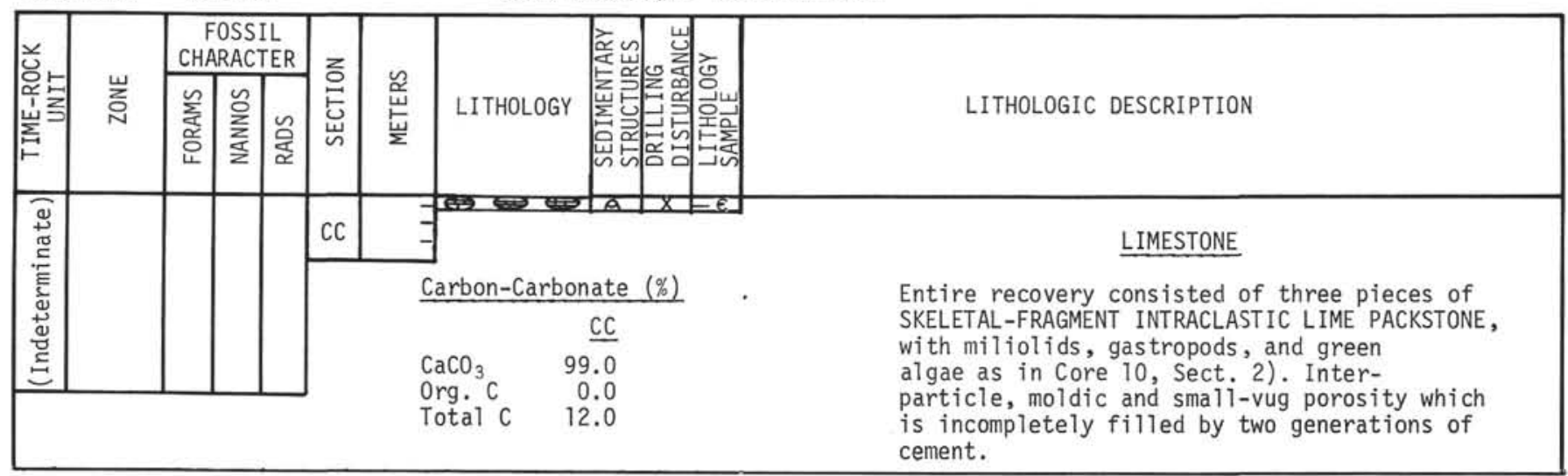




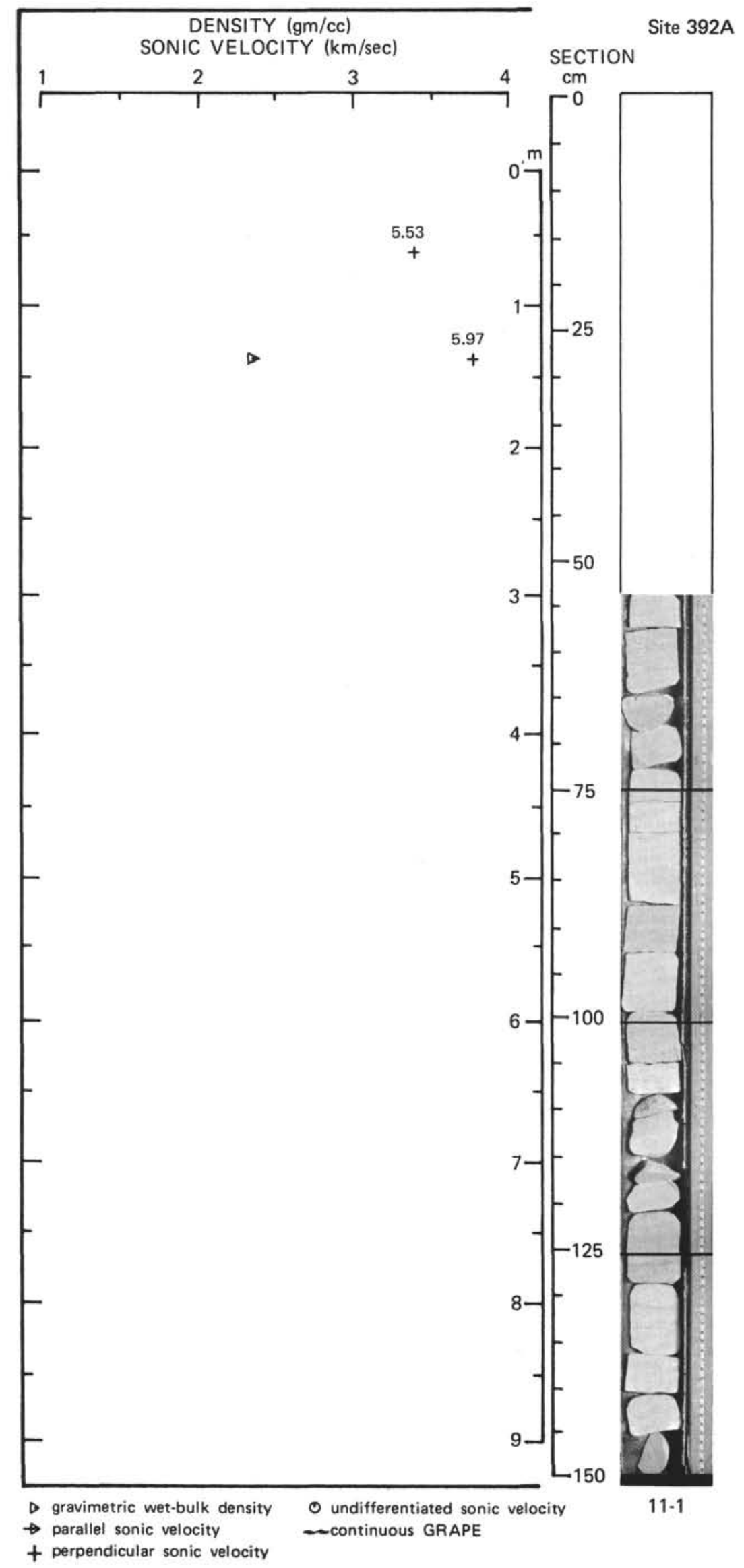




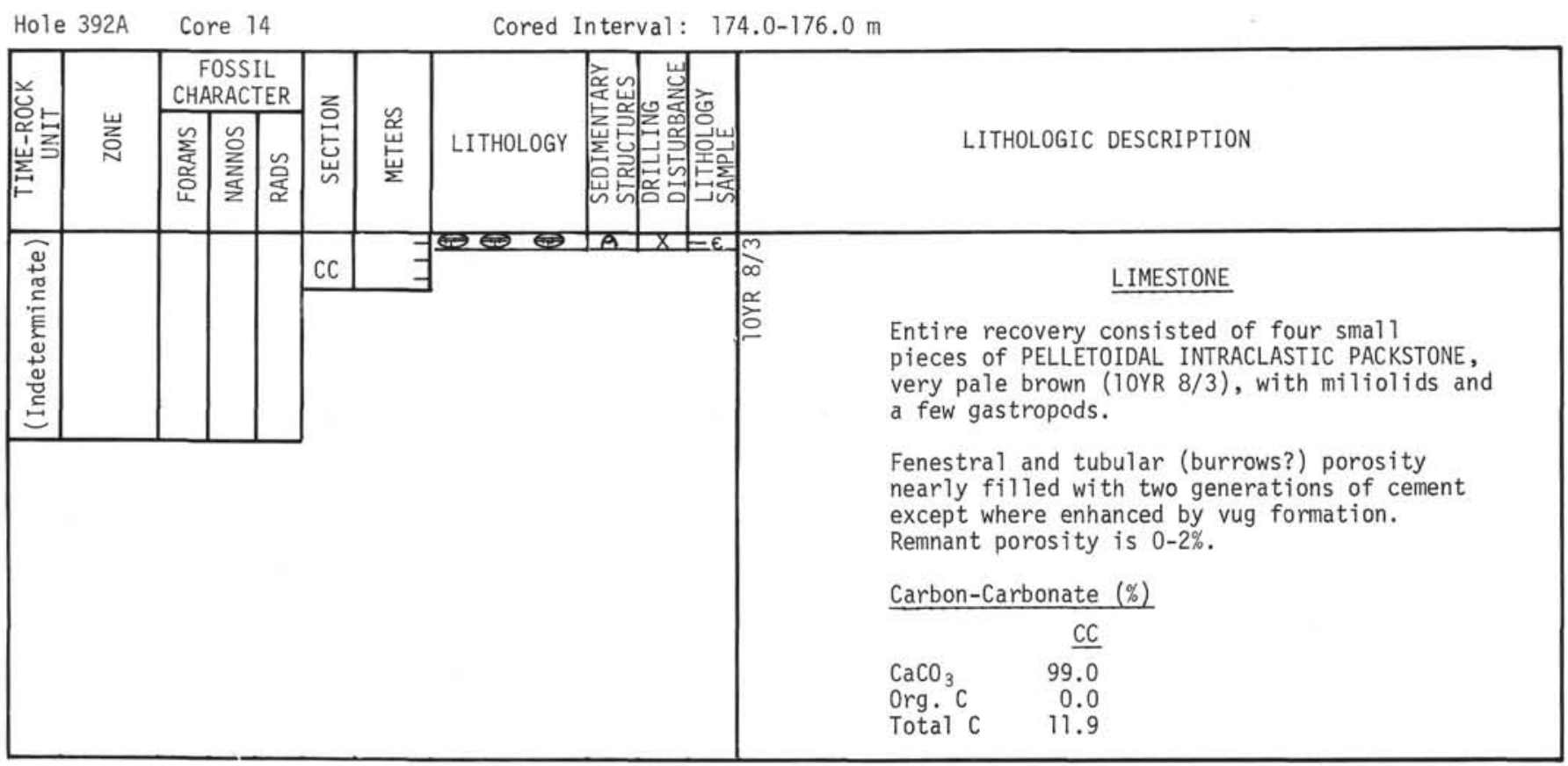

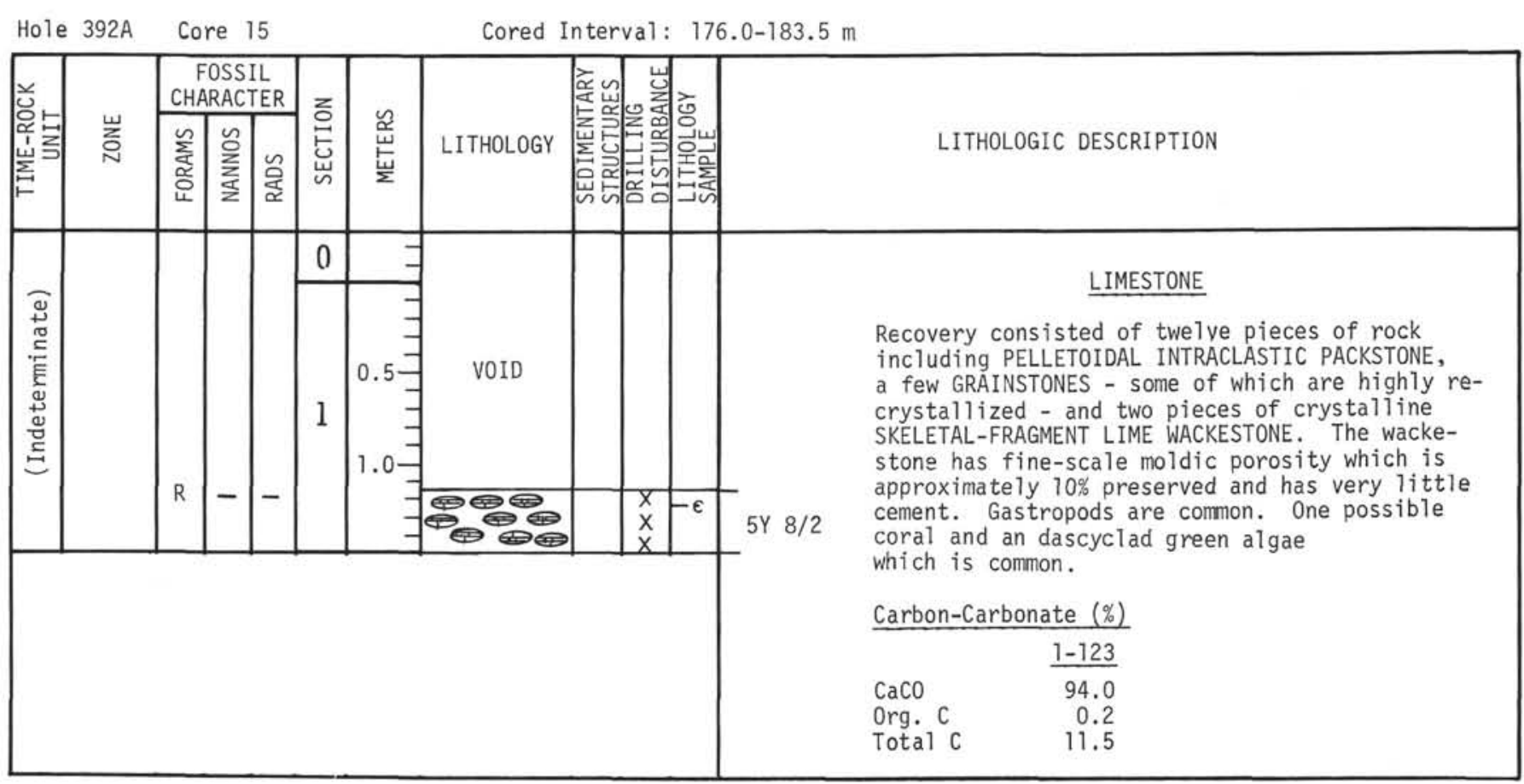




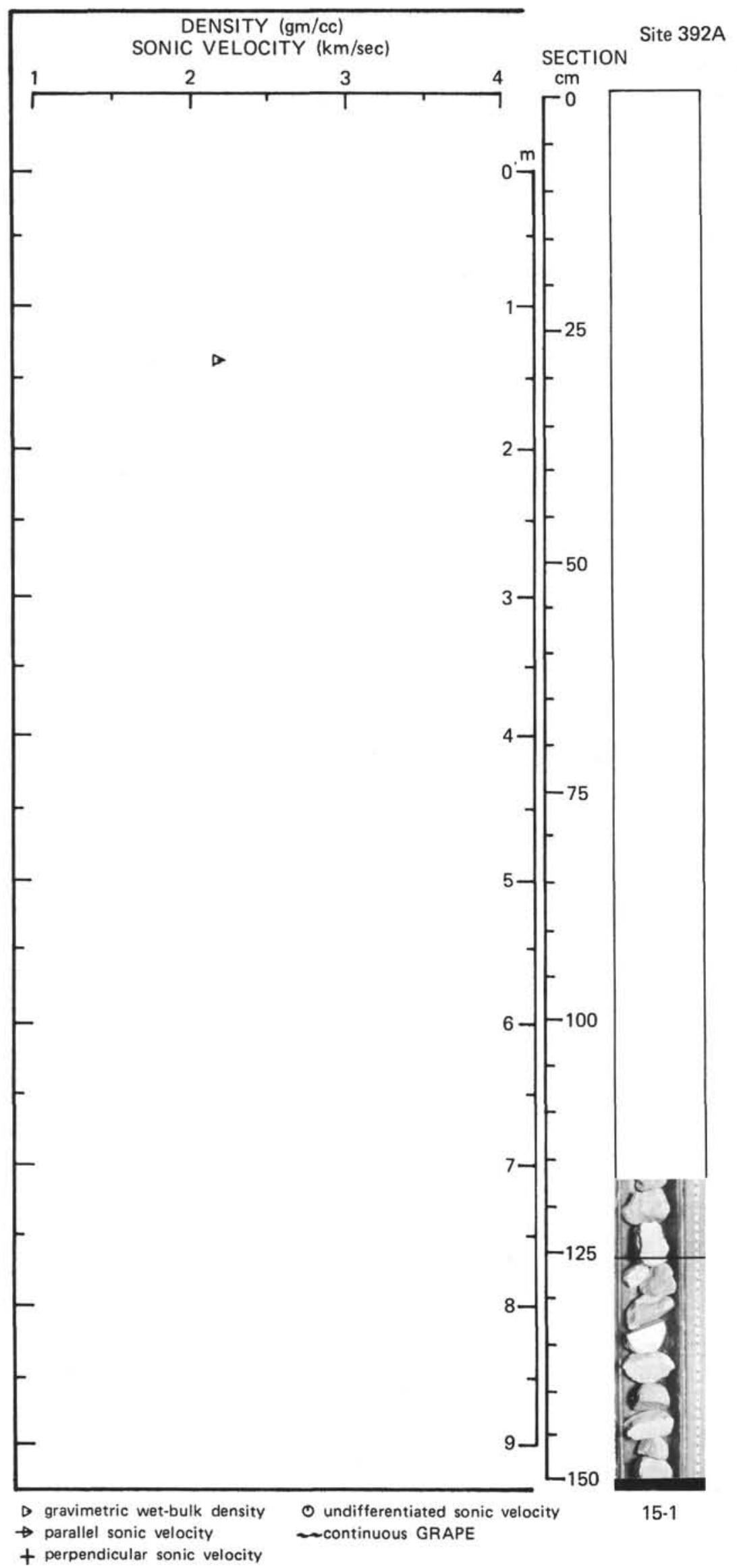




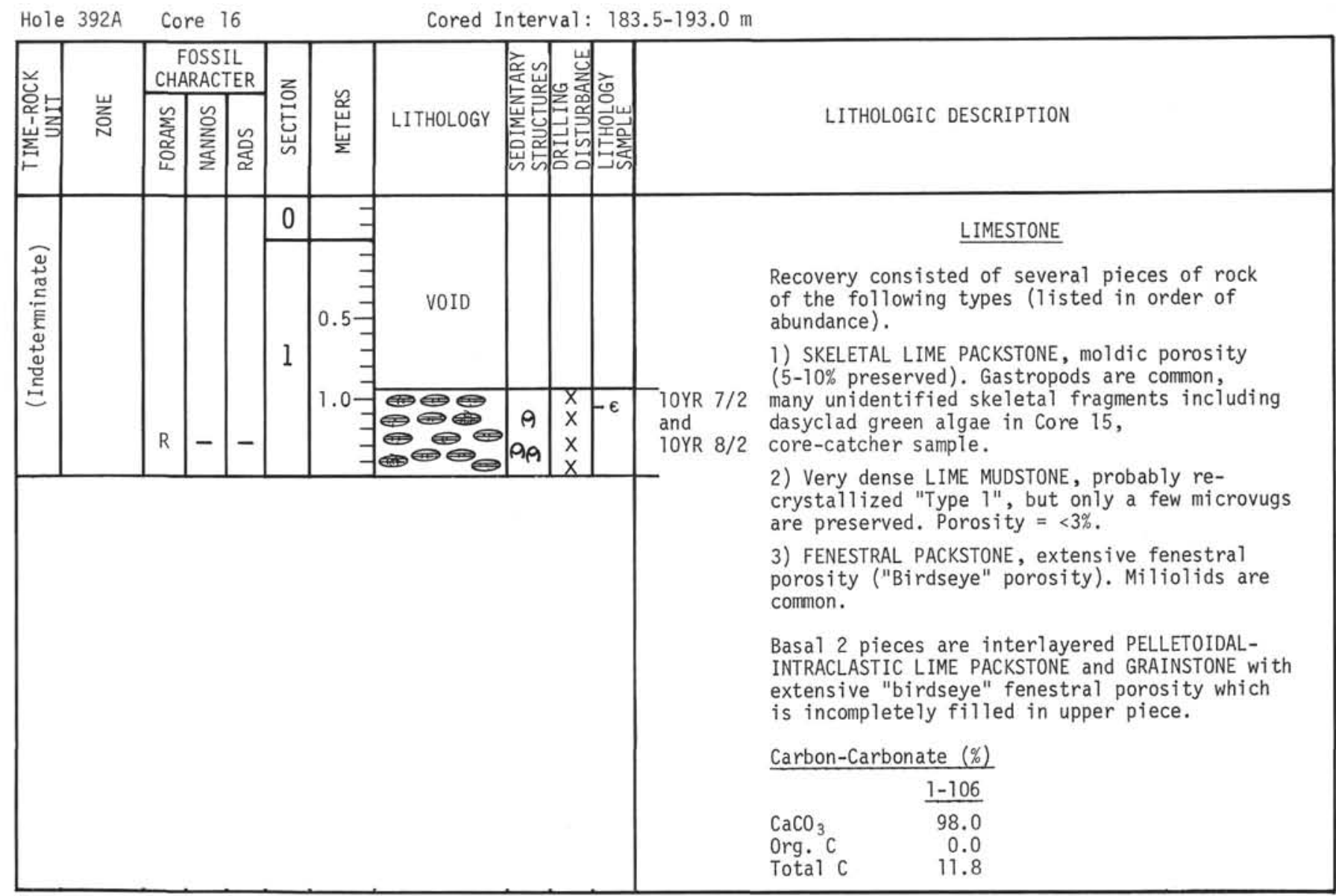

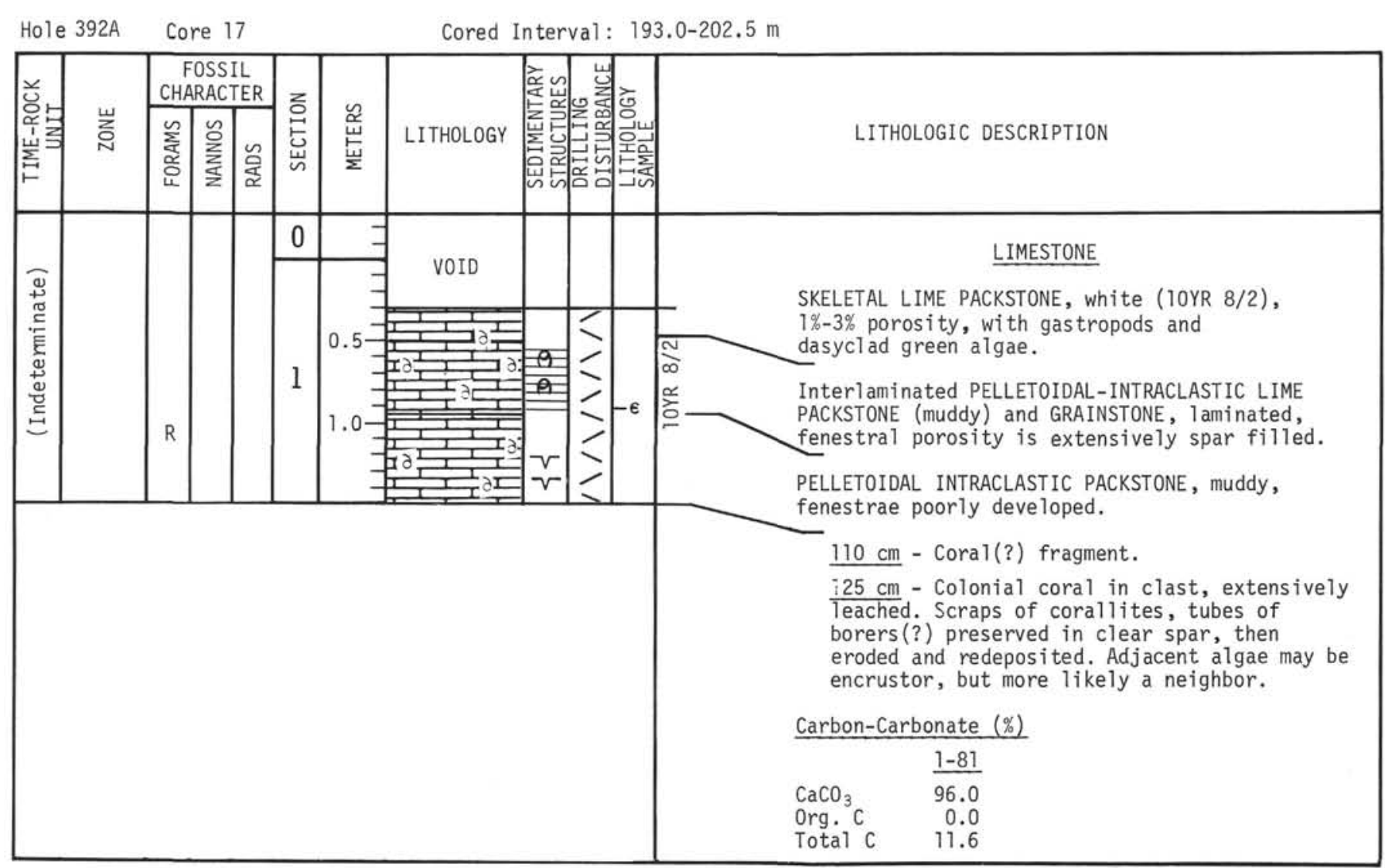




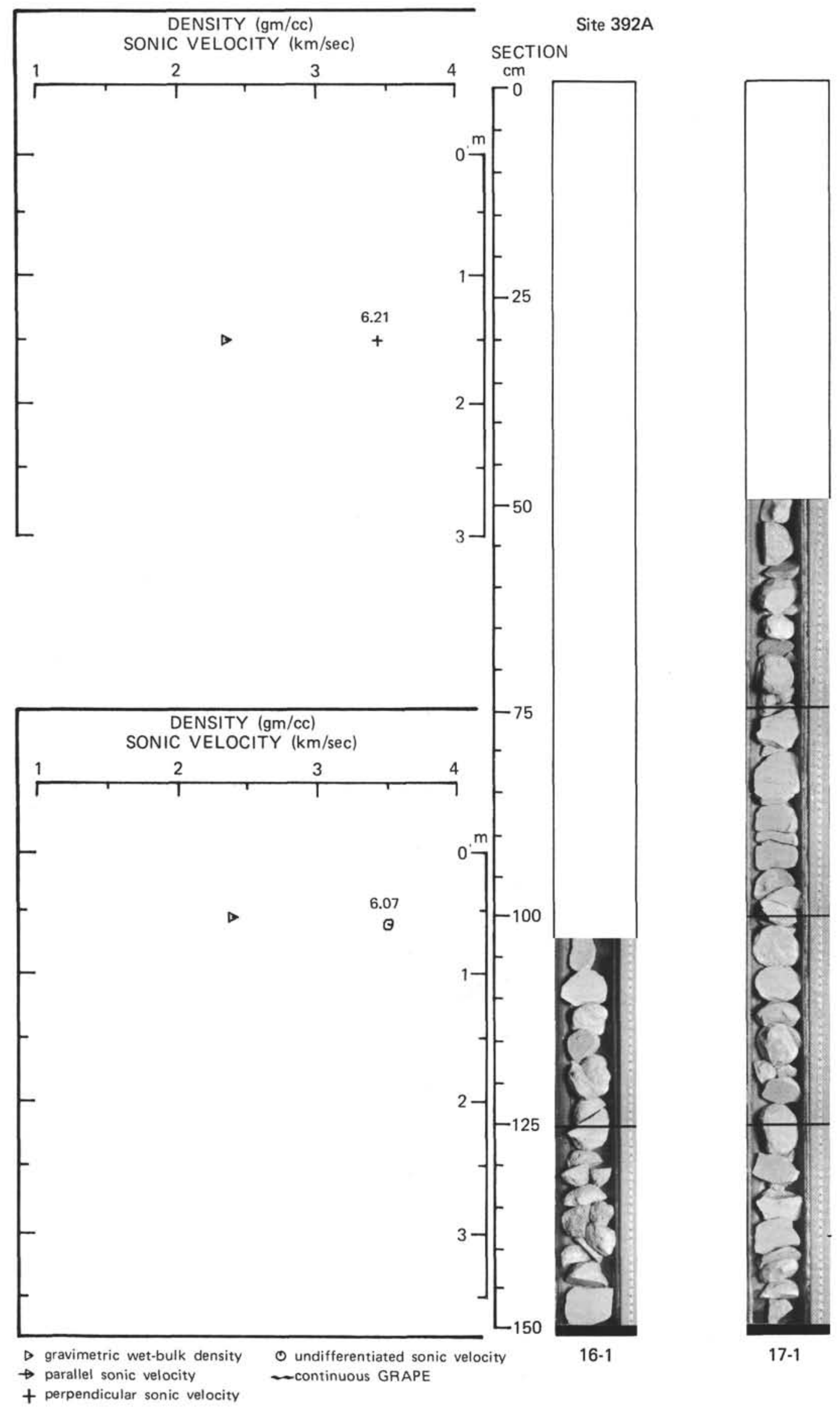




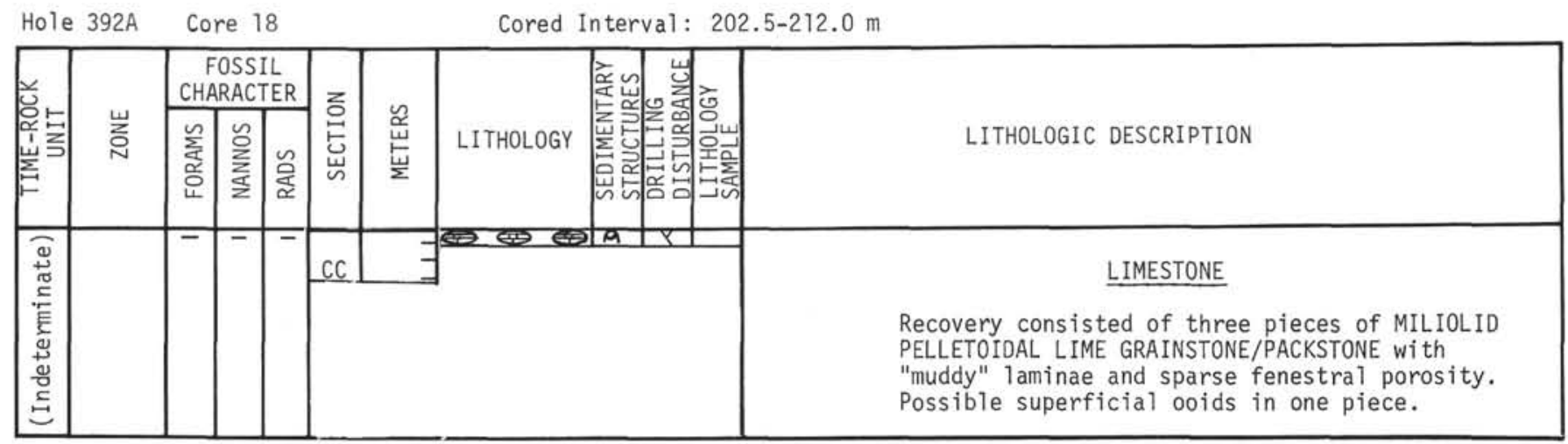

\section{Hole $392 \mathrm{~A}$ Core $19 \quad$ Cored Interval: $212.0-221.5 \mathrm{~m}$}

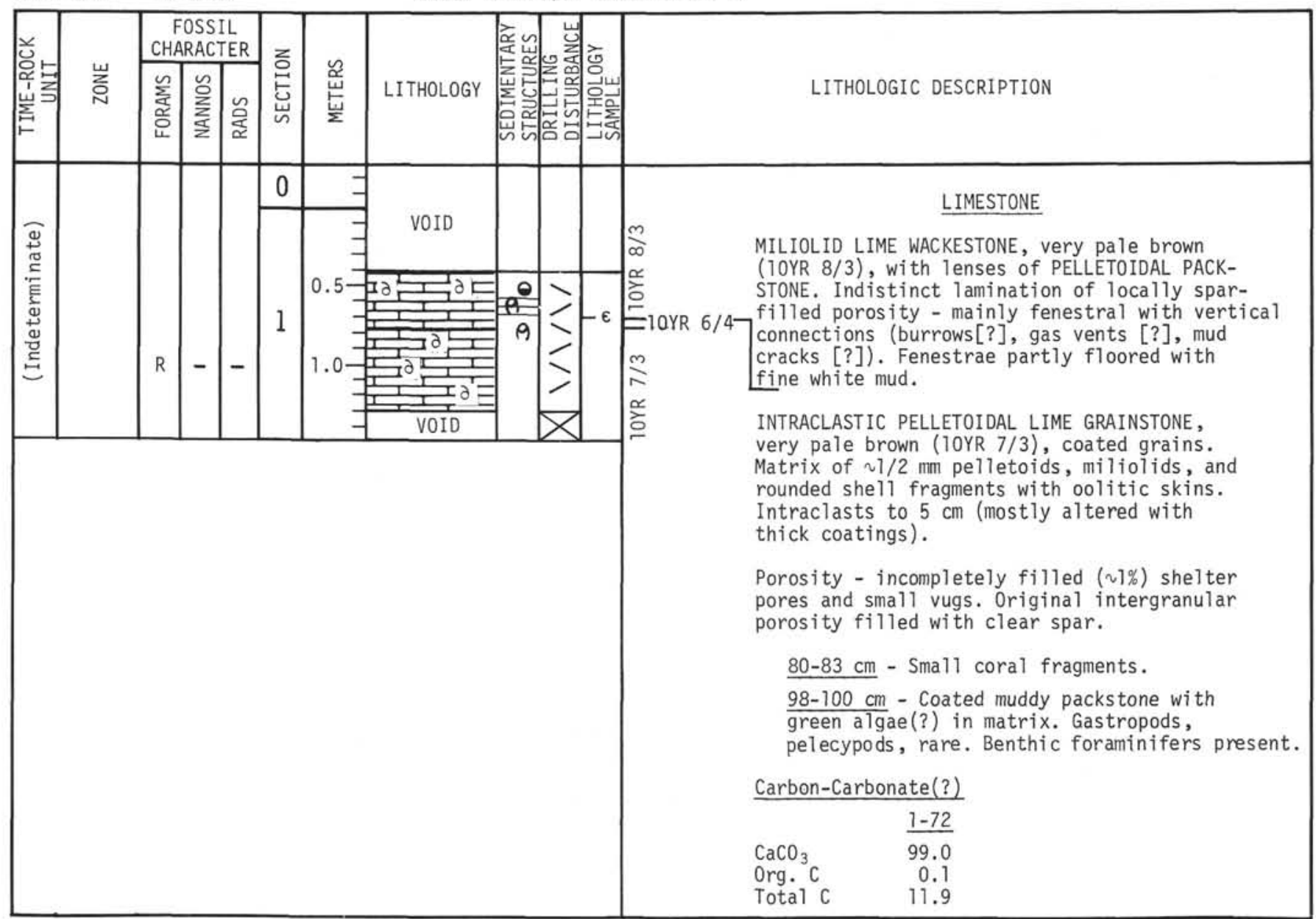




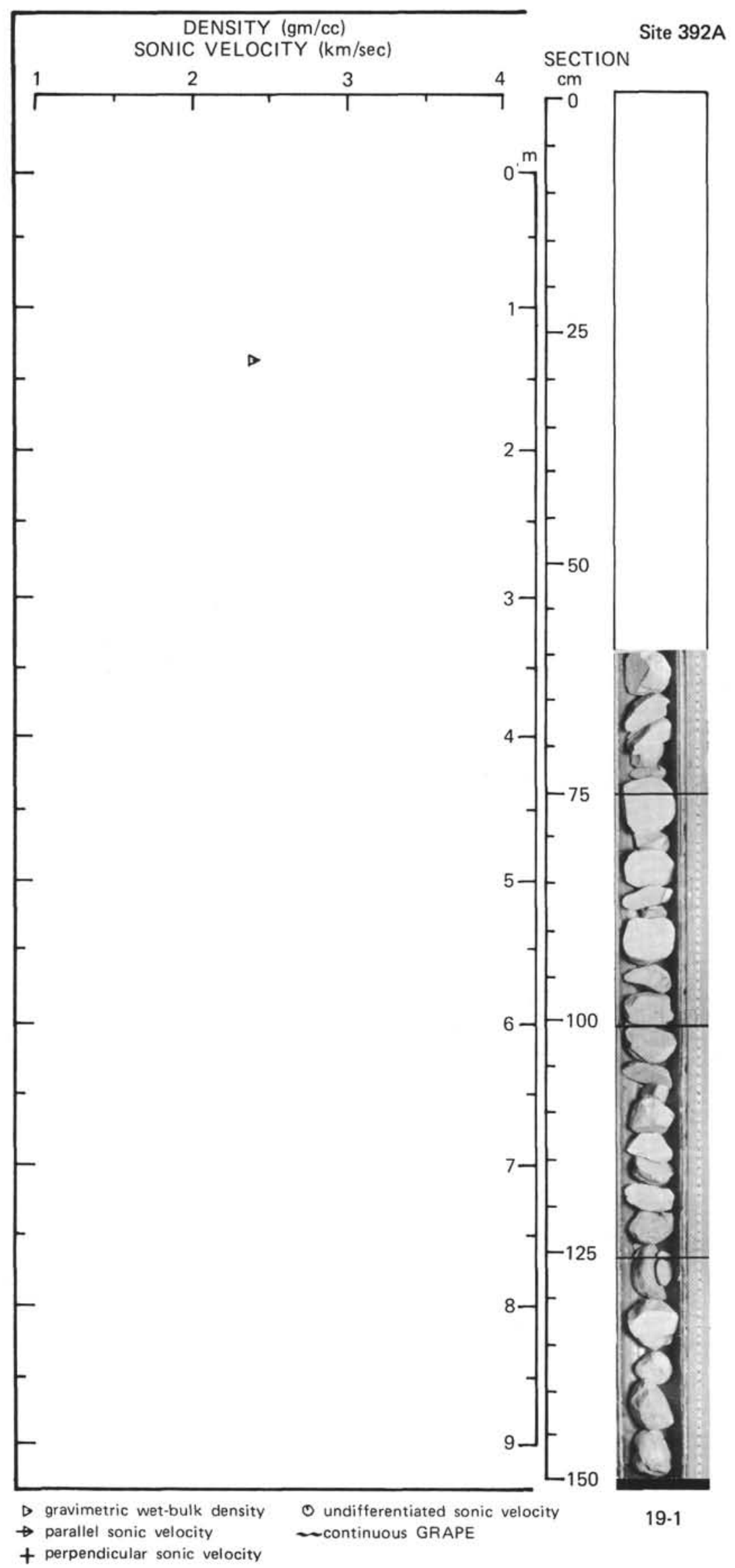


Hole 392A Core $20 \quad$ Cored Interval: $221.5-231.5 \mathrm{~m}$

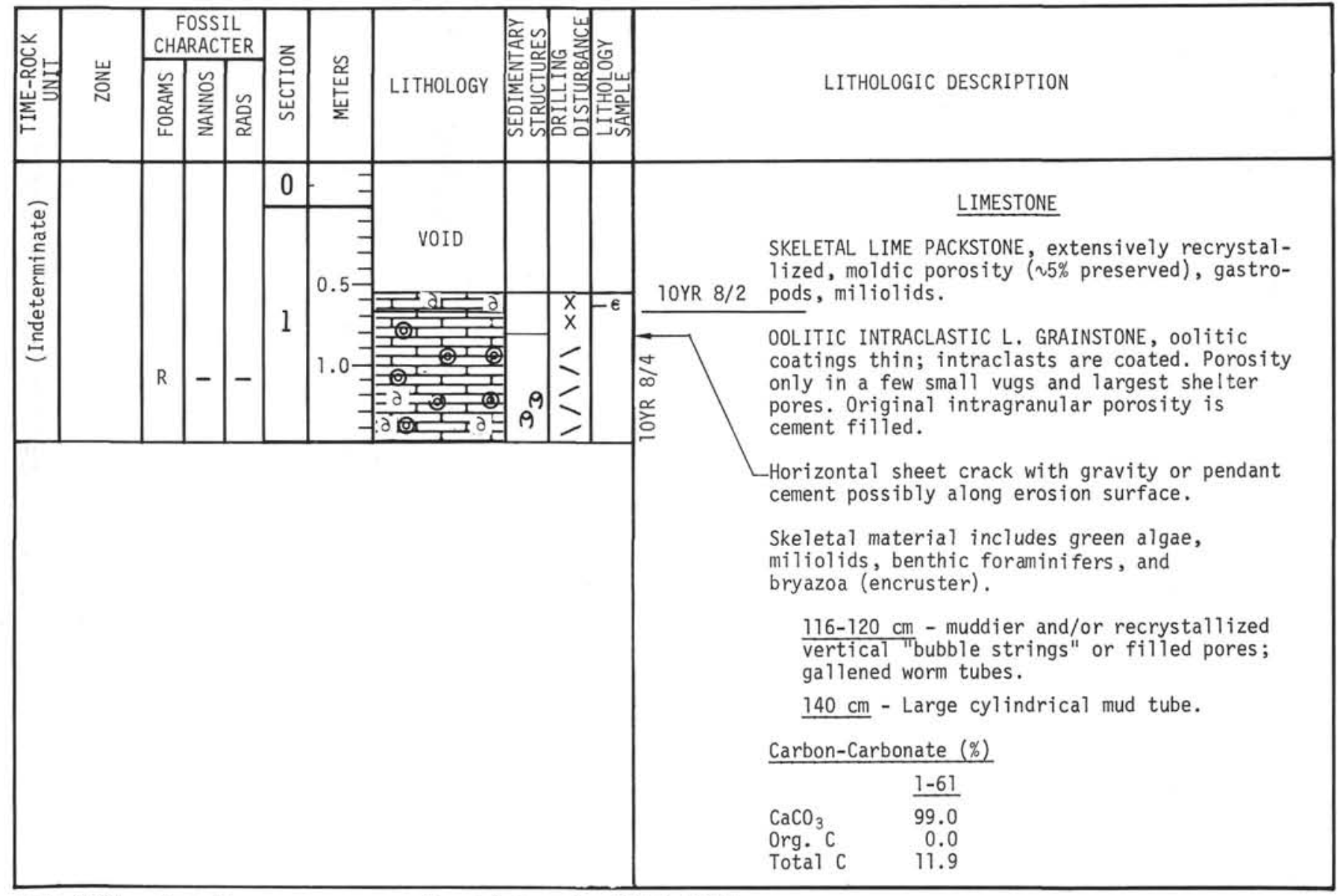

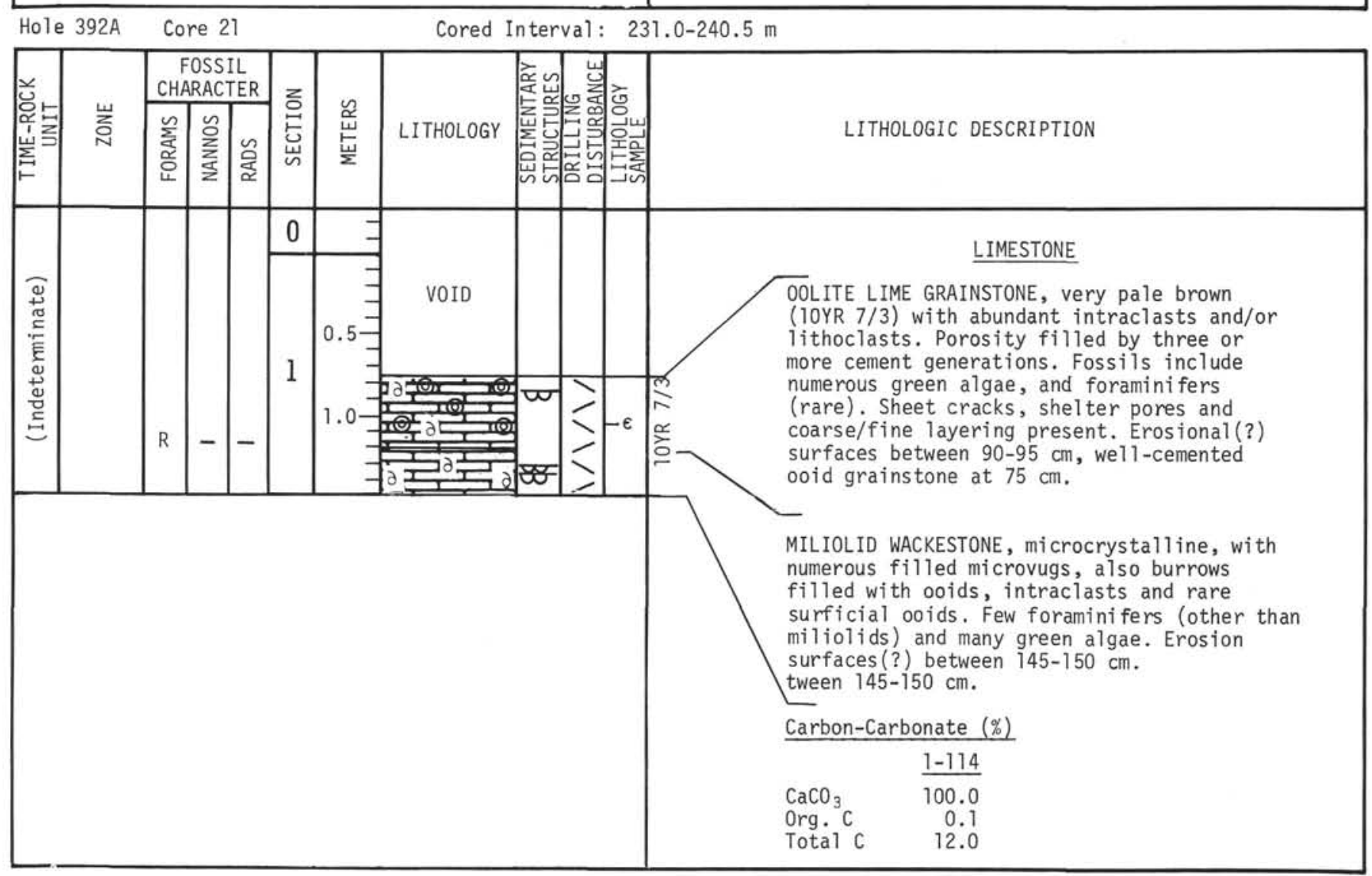



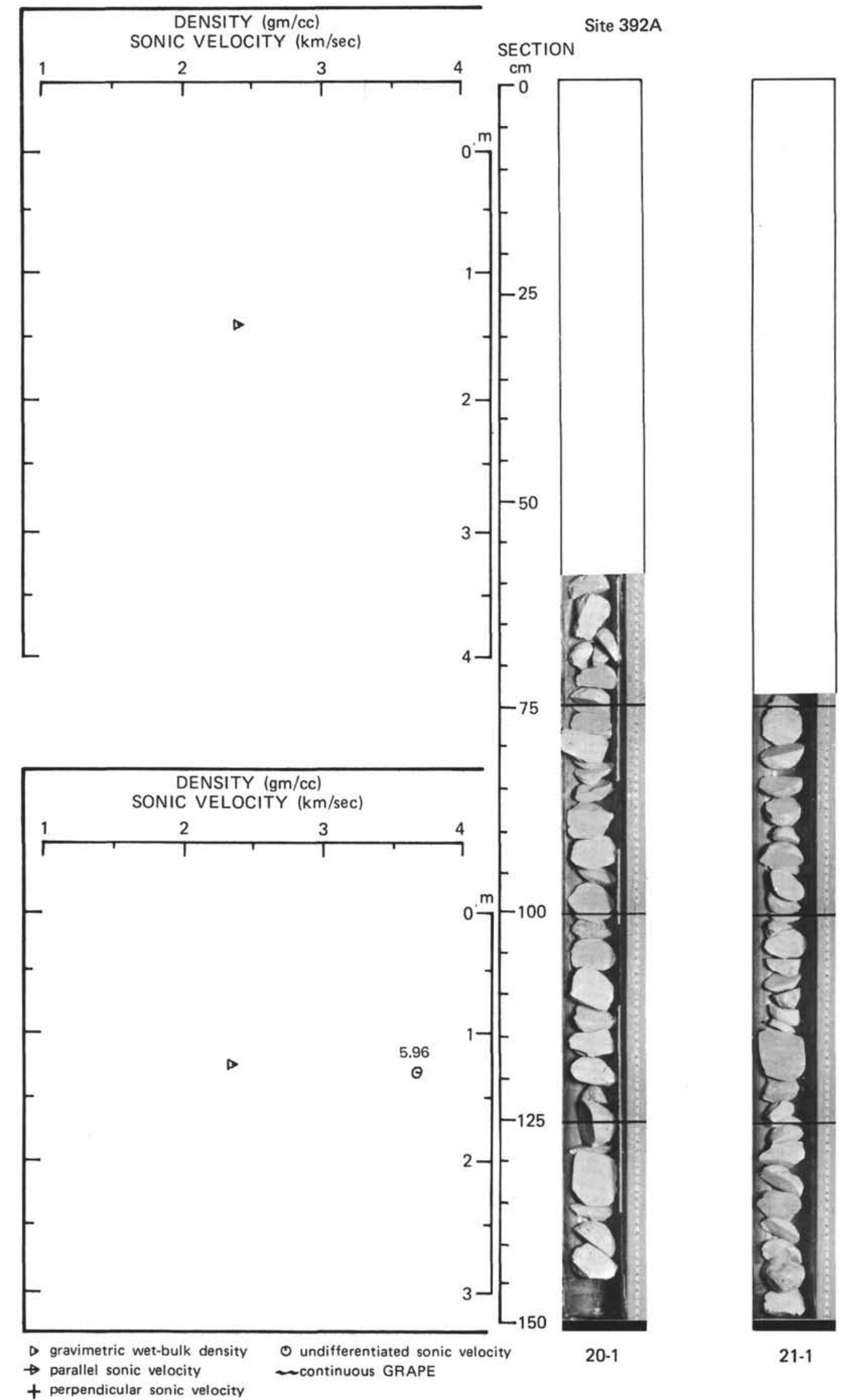

21-1 


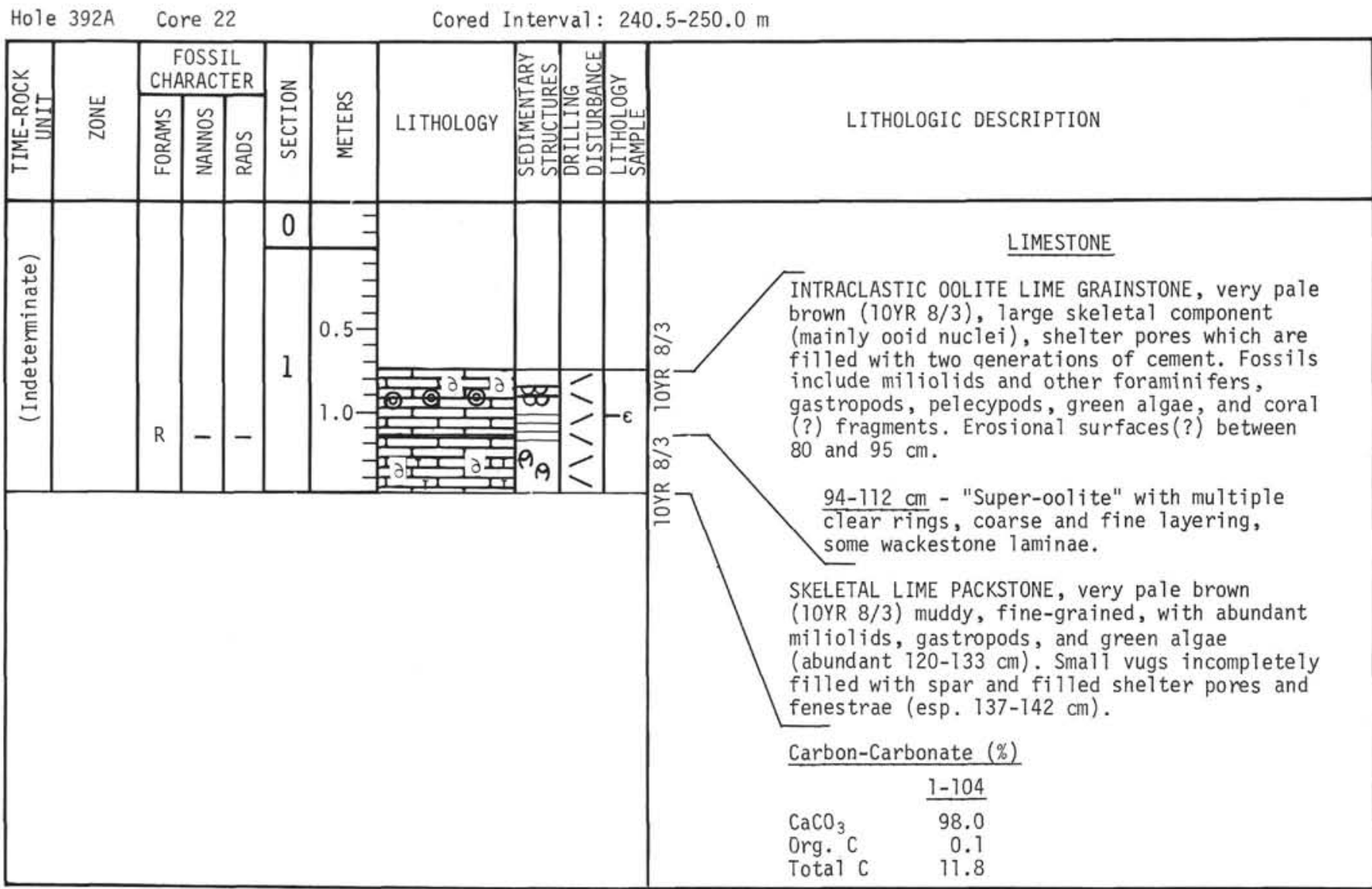

Hole 392A Core 23 Cored Interval: 250.0-259.5 m

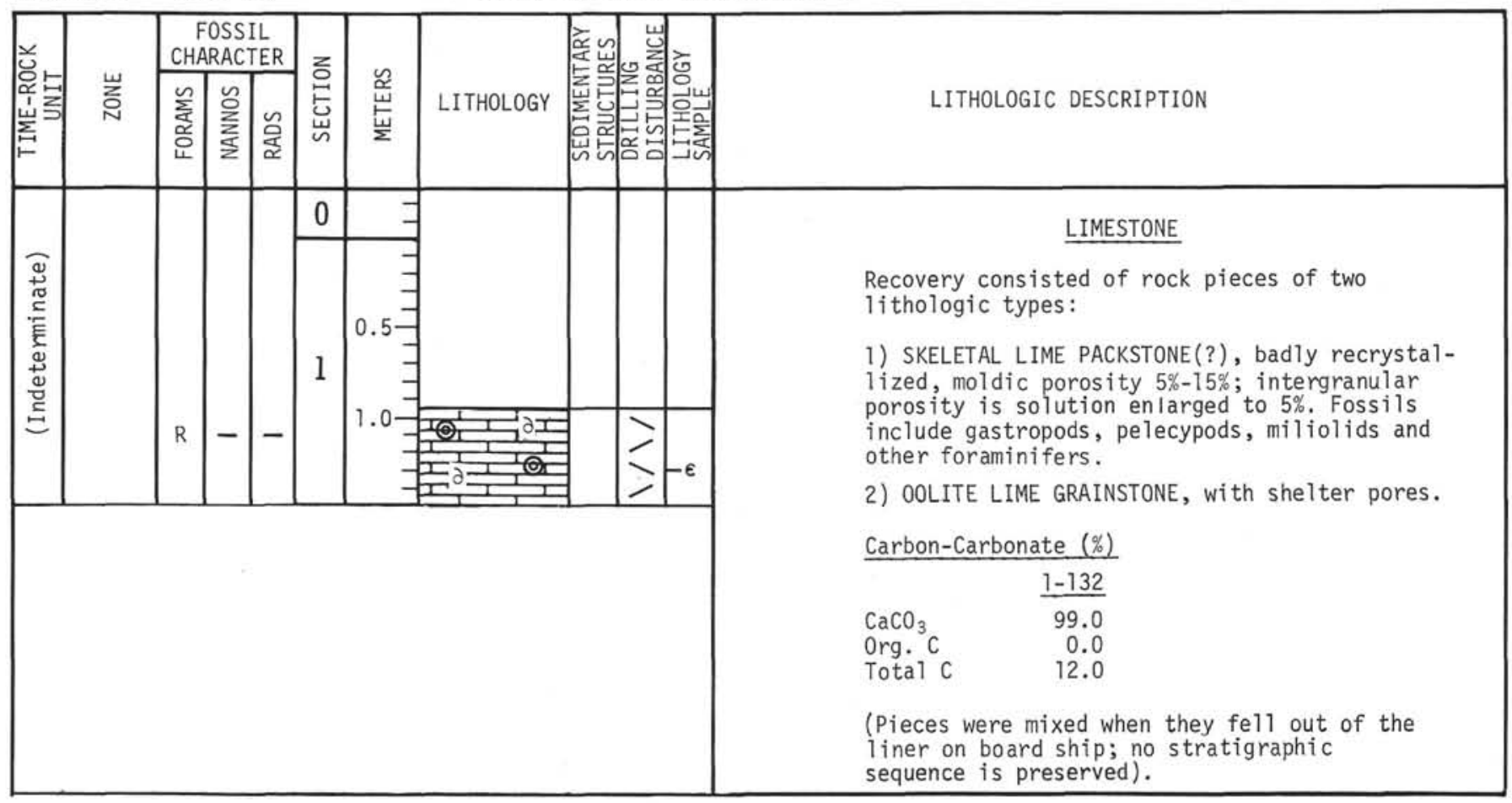




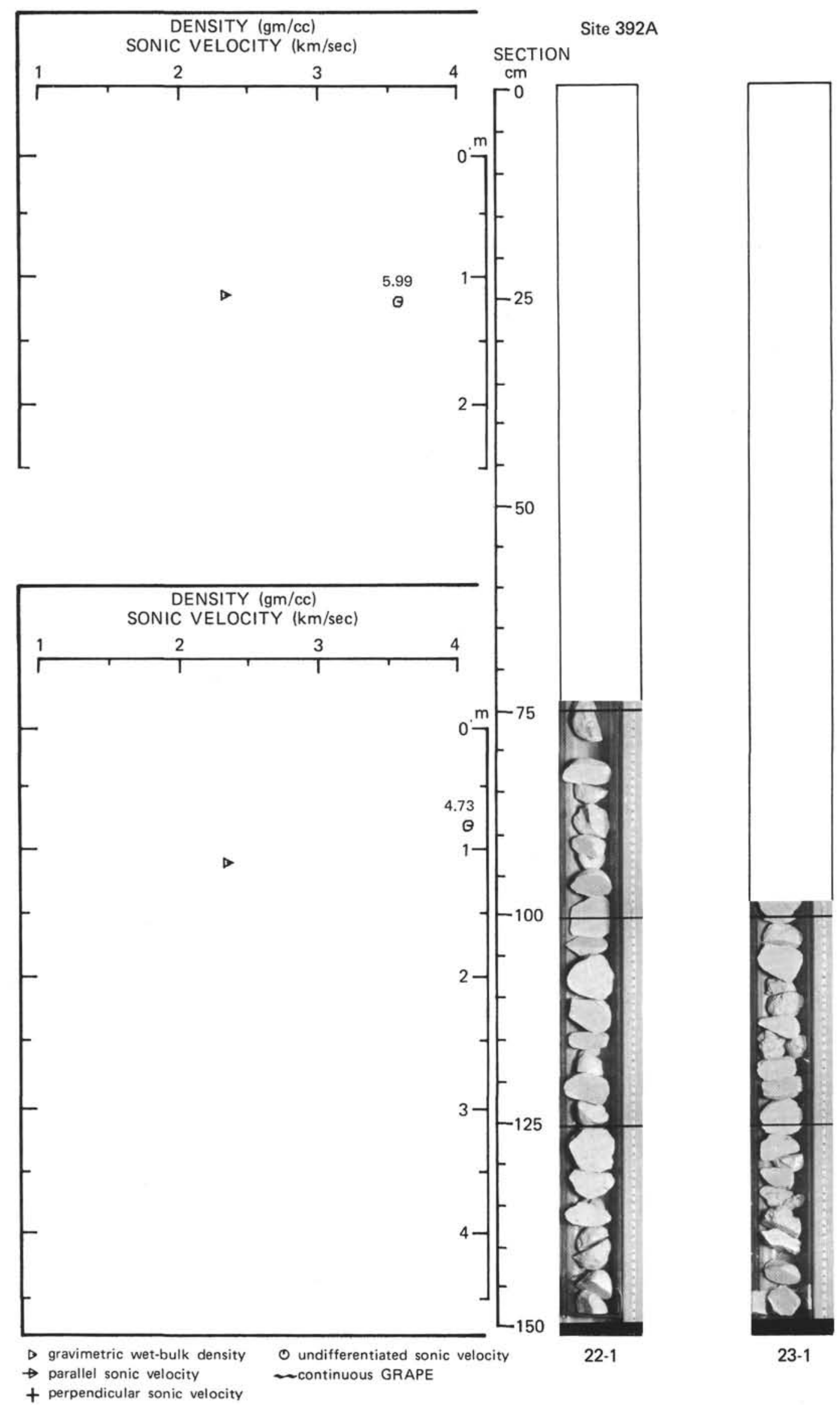




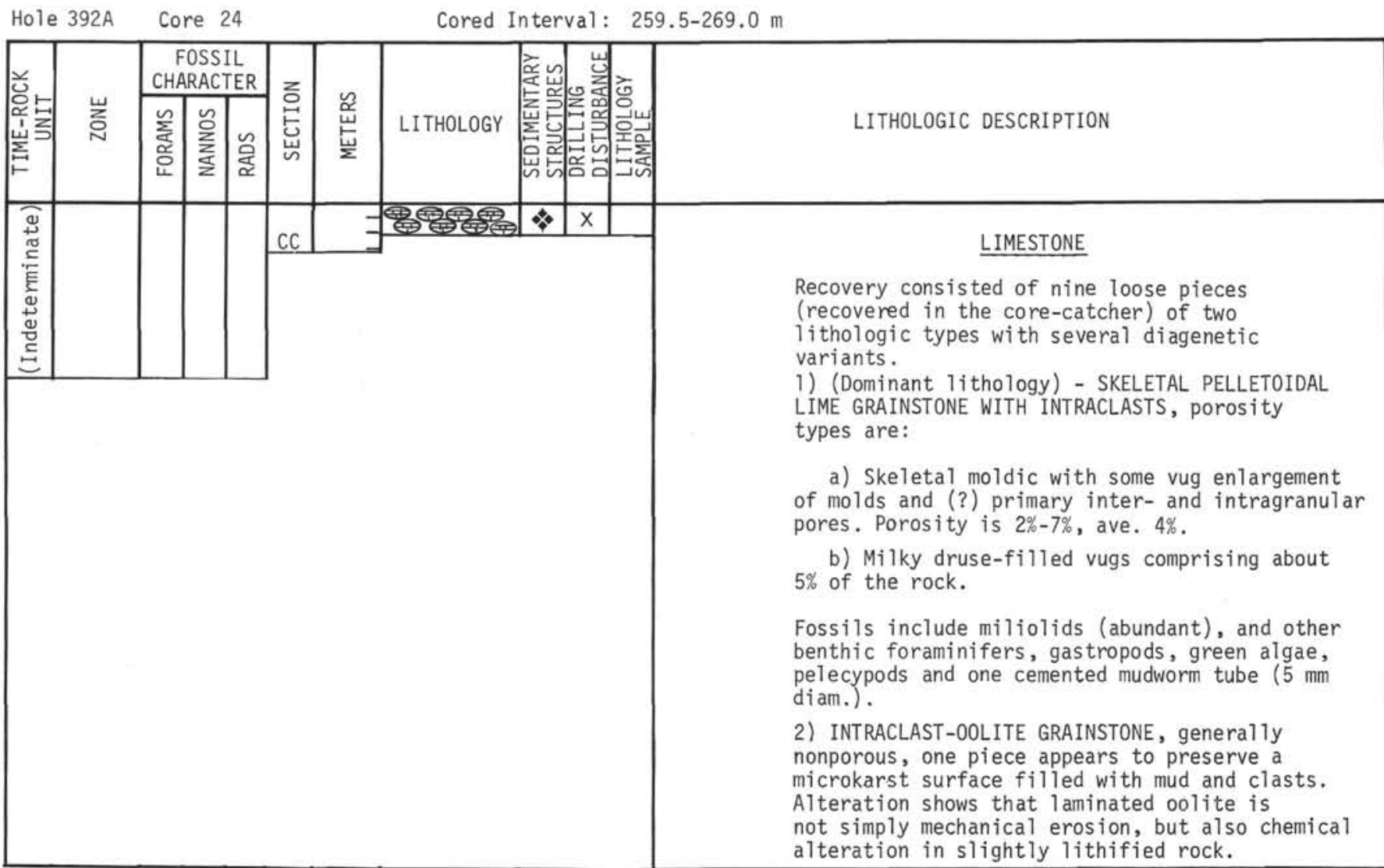

Hole $392 \mathrm{~A}$ Core $25 \quad$ Cored Interval: $269.0-278.5 \mathrm{~m}$

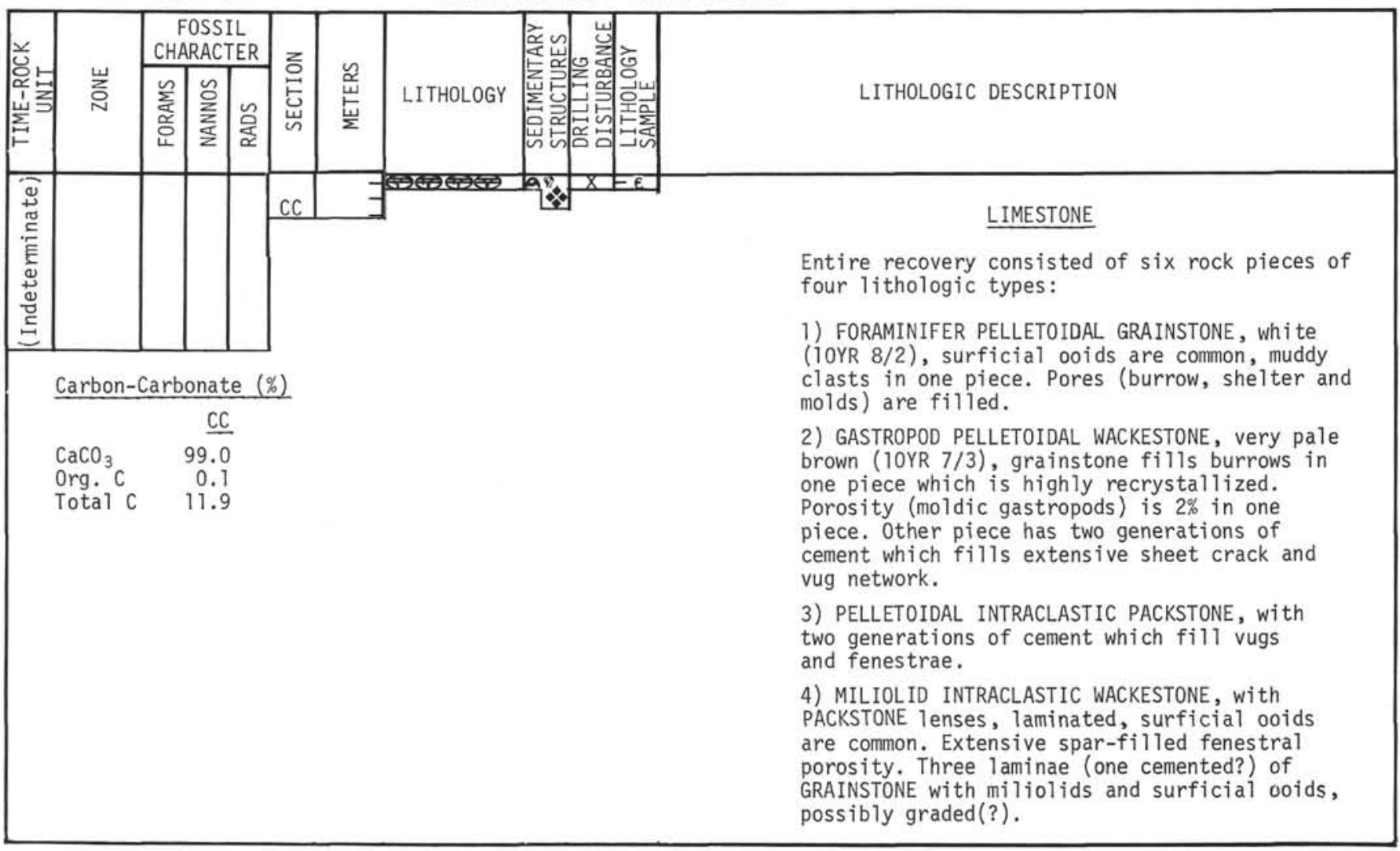





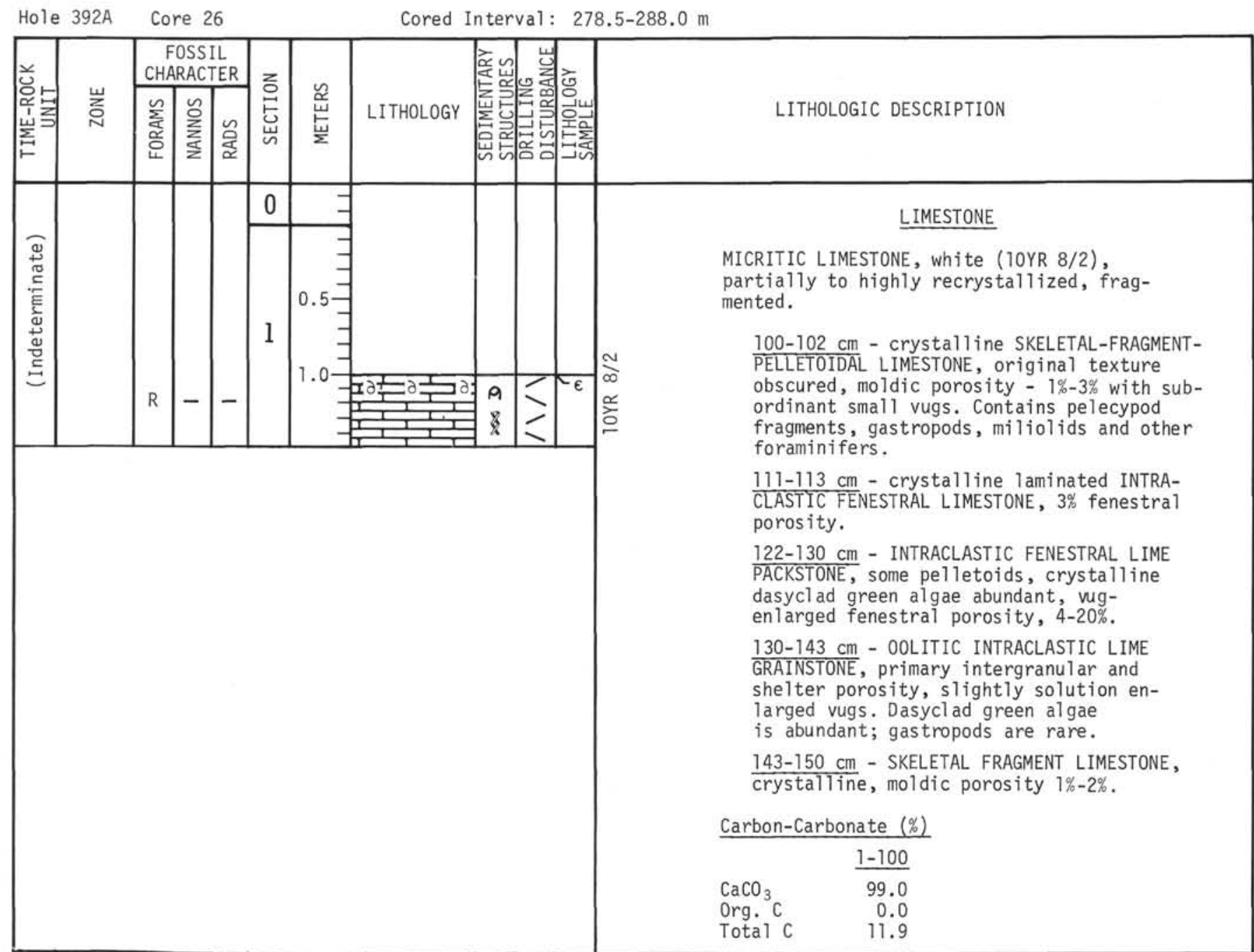

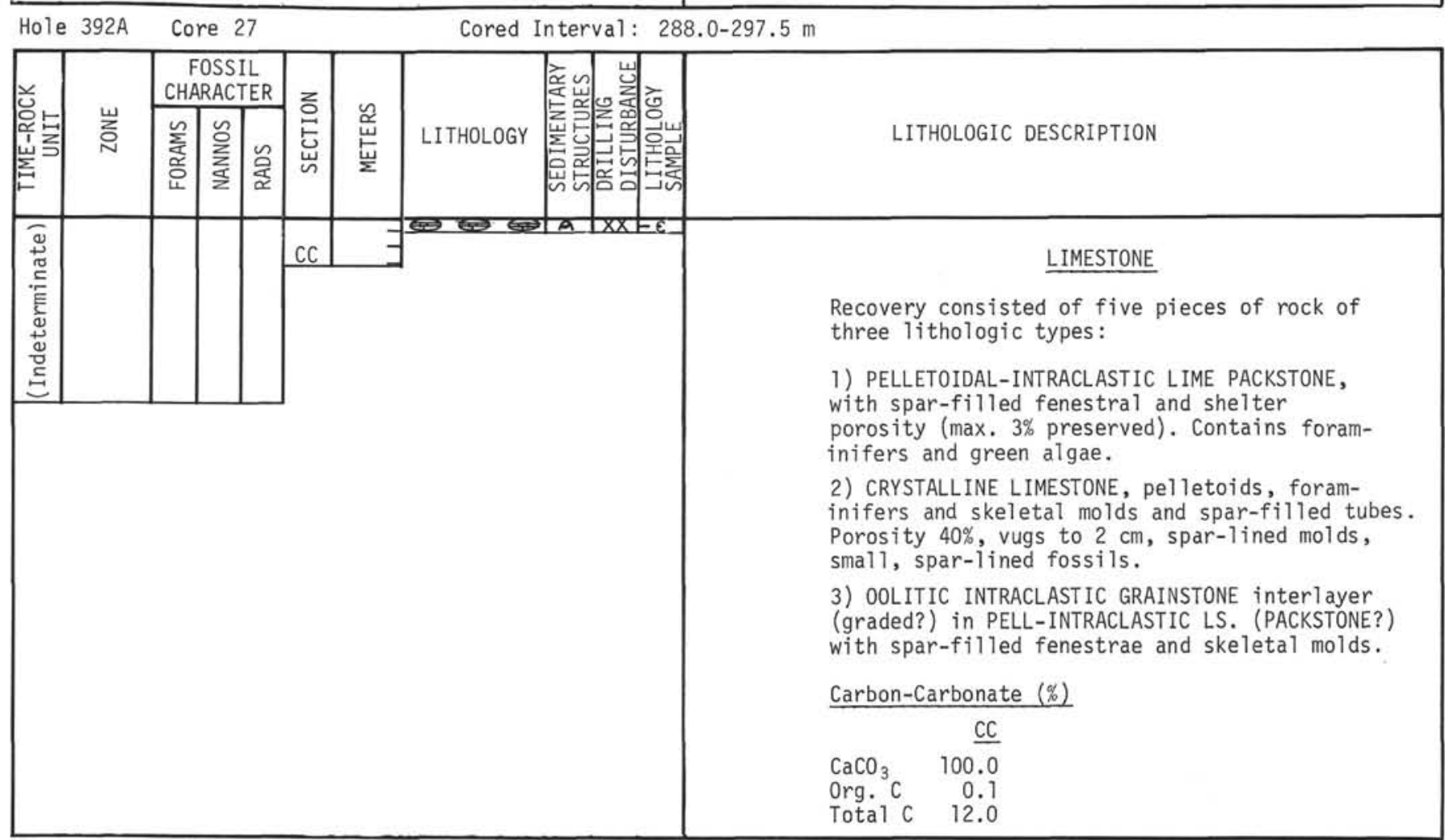




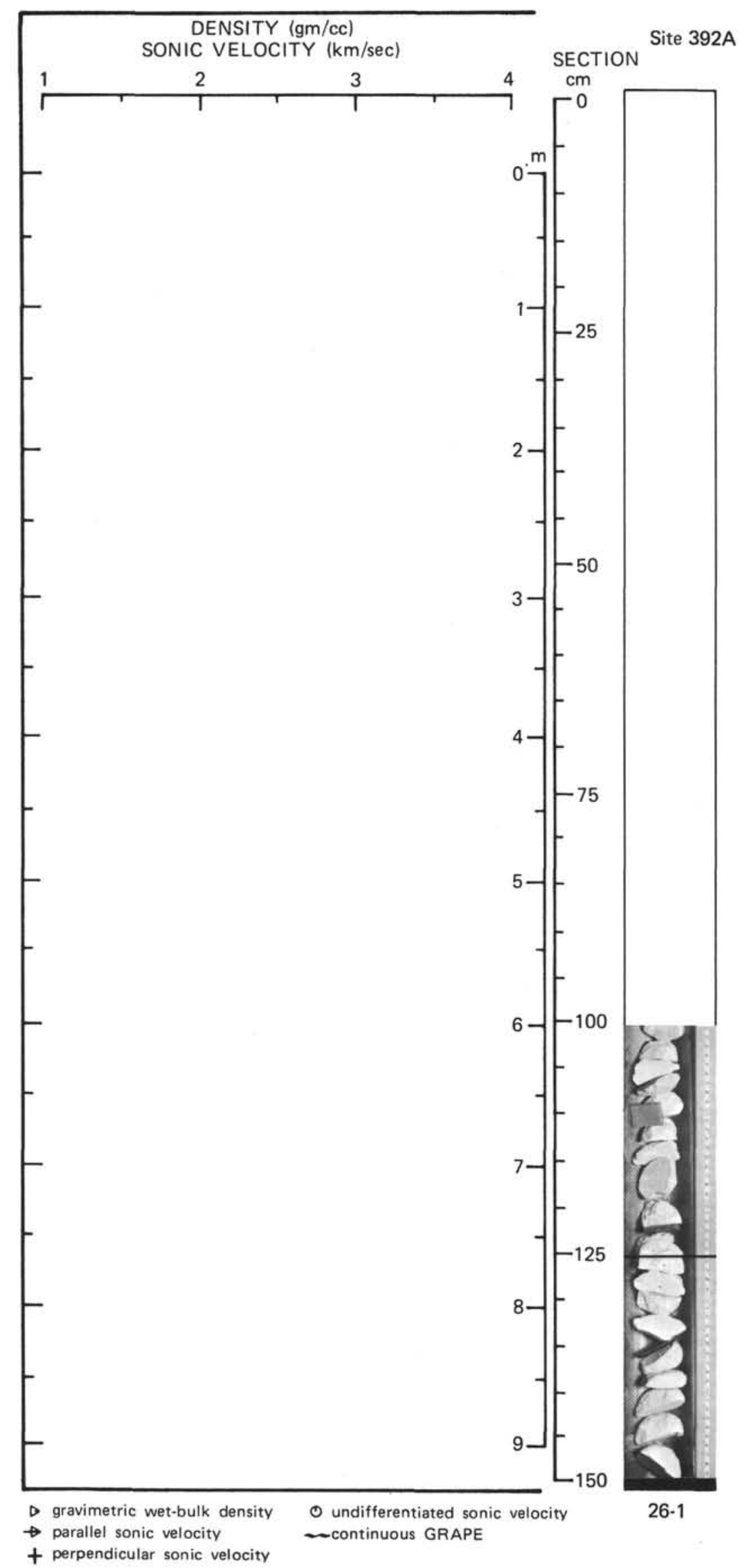




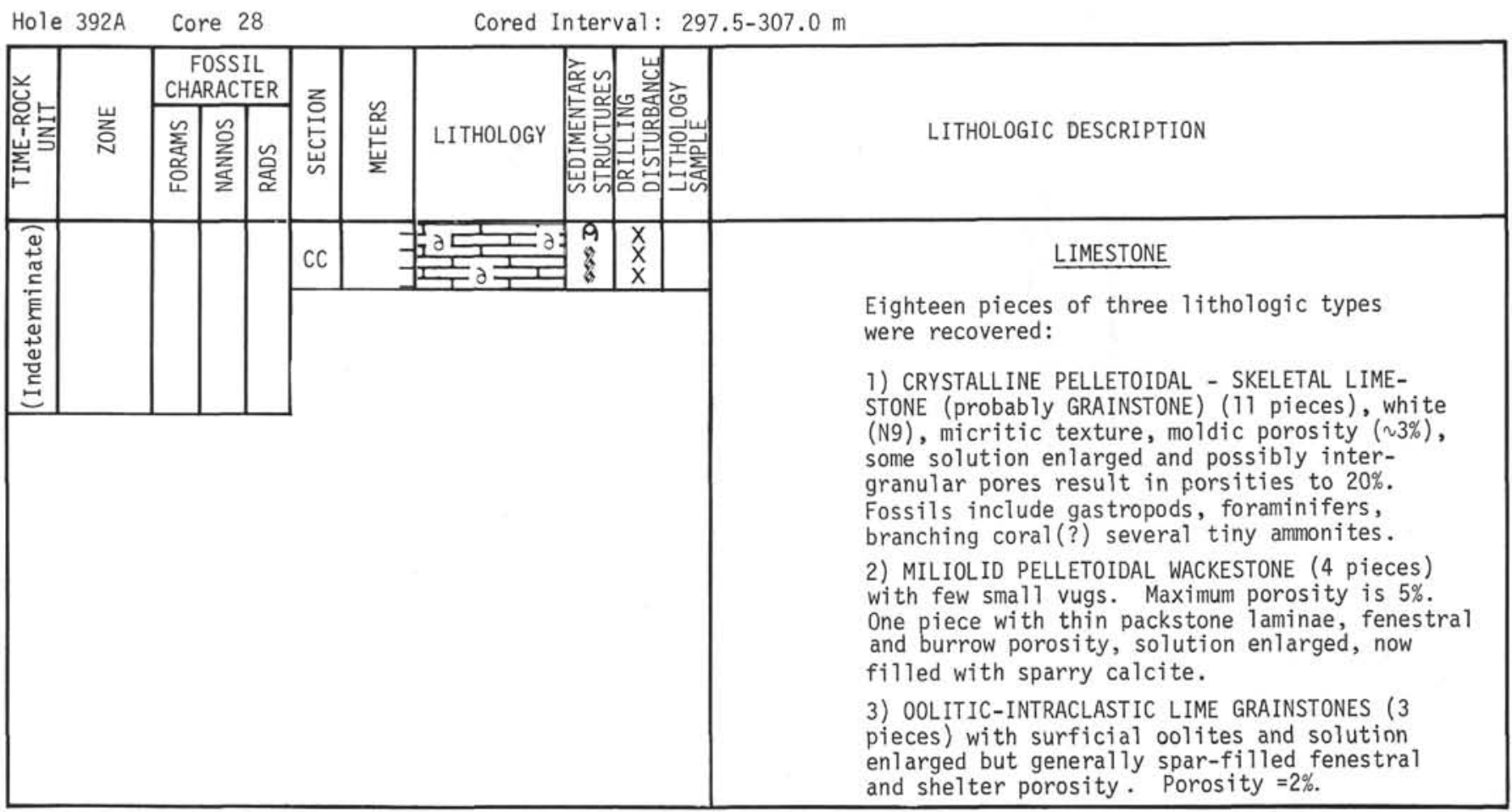

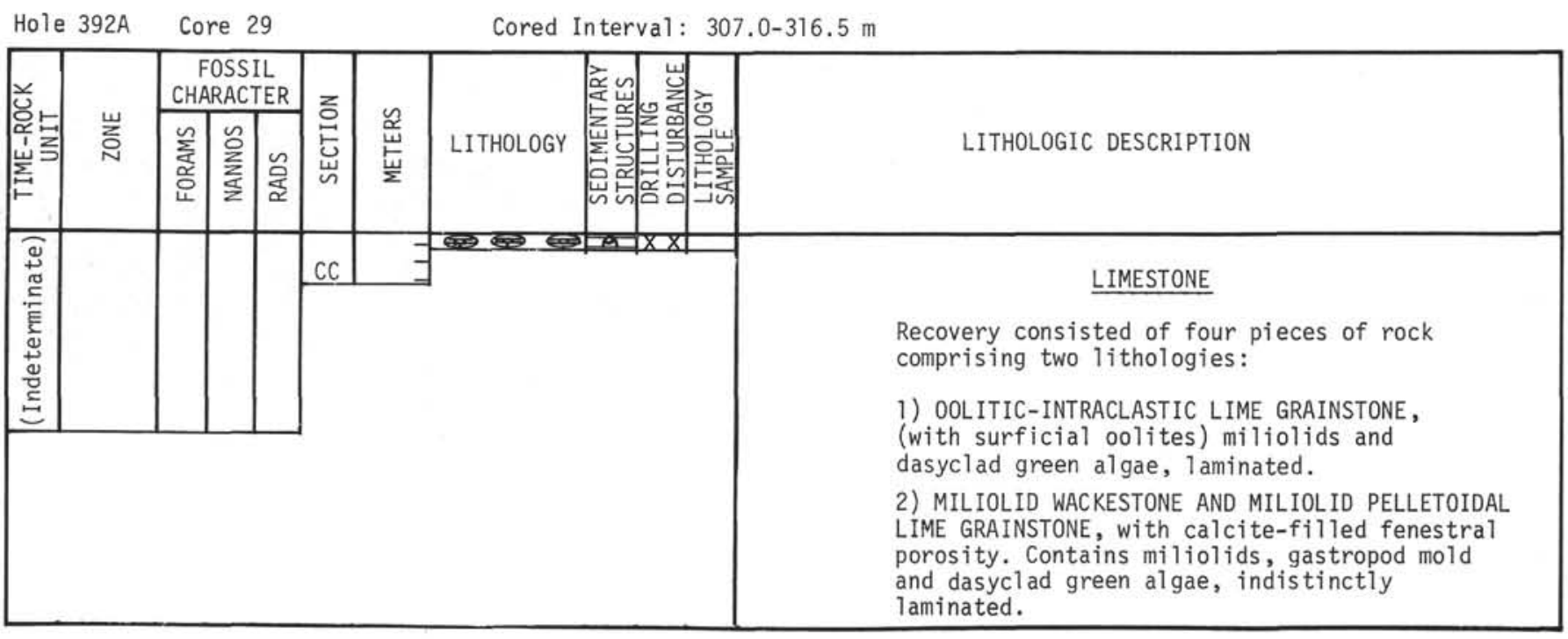




\begin{tabular}{|l|l|l|l|l|l|l|l|}
\hline Hole $392 \mathrm{~A}$ & \multicolumn{2}{c}{ Core 30} & \\
\hline
\end{tabular}

Hole $392 \mathrm{~A}$ Core $31 \quad$ Cored Interval: $326.0-335.5 \mathrm{~m}$

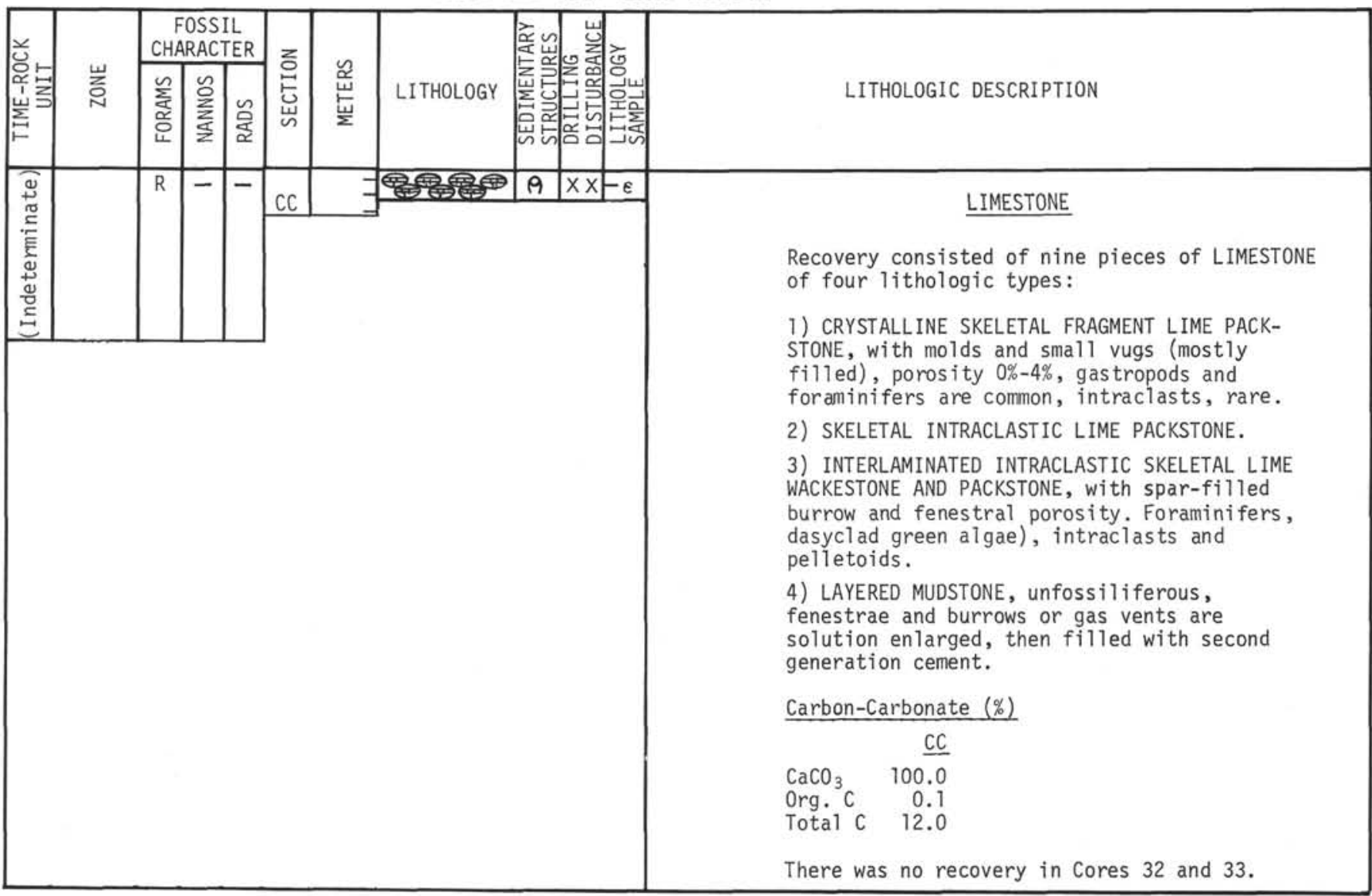

